\title{
Standardized Pathology Report for Colorectal Cancer, 2nd Edition
}

\author{
Baek-hui Kim ${ }^{1}$, Joon Mee Kim², Gyeong Hoon Kang ${ }^{3}$, Hee Jin Chang', Dong Wook Kang ${ }^{5}$, Jung Ho Kim³, \\ Jeong Mo Bae ${ }^{3}$, An Na Seo ${ }^{6}$, Ho Sung Park ${ }^{7}$, Yun Kyung Kang ${ }^{8}$, Kyung-Hwa Lee, Mee Yon Cho ${ }^{10}$, In-Gu Do ${ }^{11}$, \\ Hye Seung Lee ${ }^{12}$, Hee Kyung Chang ${ }^{13}$, Do Youn Park ${ }^{14}$, Hyo Jeong Kang ${ }^{15}$, Jin Hee Sohn ${ }^{11}$, Mee Soo Chang ${ }^{16}$, \\ Eun Sun Jung ${ }^{17}$, So-Young Jin ${ }^{18}$, Eunsil Yu ${ }^{15}$, Hye Seung Han ${ }^{19}$, Youn Wha Kim ${ }^{20}$, \\ The Gastrointestinal Pathology Study Group of the Korean Society of Pathologists \\ 'Department of Pathology, Korea University Guro Hospital, Seoul; ²Department of Pathology, Inha University School of Medicine, Incheon; \\ ${ }^{3}$ Department of Pathology, Seoul National University Hospital, Seoul National University College of Medicine, Seoul; \\ ${ }^{4}$ Department of Pathology, Research Institute and Hospital, National Cancer Center, Goyang; ${ }^{5}$ Department of Pathology, Eulji University Hospital, \\ Eulji University School of Medicine, Daejeon; ${ }^{6}$ Department of Pathology, School of Medicine, Kyungpook National University, Daegu; \\ ${ }^{7}$ Department of Pathology, Chonbuk National University Medical School, Jeonju; ${ }^{8}$ Department of Pathology, Seoul Paik Hospital, Inje University College of Medicine, Seoul; \\ ${ }^{9}$ Department of Pathology, Chonnam National University Medical School, Gwangju; ${ }^{10}$ Department of Pathology, Yonsei University Wonju College of Medicine, Wonju; \\ ${ }^{11}$ Department of Pathology, Kangbuk Samsung Hospital, Sungkyunkwan University School of Medicine, Seoul; ${ }^{12}$ Department of Pathology, Seoul National University \\ Bundang Hospital, Seongnam; ${ }^{13}$ Department of Pathology, Kosin University College of Medicine, Busan; ${ }^{14}$ Department of Pathology, Pusan National University Hospital, \\ Pusan National University School of Medicine, Busan; ${ }^{15}$ Department of Pathology, Asan Medical Center, University of Ulsan College of Medicine, Seoul; \\ ${ }^{16}$ Department of Pathology, Seoul National University Boramae Hospital, Seoul National University College of Medicine, Seoul; ${ }^{17 D e p a r t m e n t ~ o f ~ H o s p i t a l ~ P a t h o l o g y, ~}$ \\ College of Medicine, The Catholic University of Korea, Seoul; ${ }^{18}$ Department of Pathology, Soonchunhyang University Seoul Hospital, Soonchunhyang University \\ College of Medicine, Seoul; ${ }^{19}$ Department of Pathology, Konkuk University Medical Center, Konkuk University School of Medicine, Seoul; \\ ${ }^{20}$ Department of Pathology, Kyung Hee University College of Medicine, Seoul, Korea
}

The first edition of the 'Standardized Pathology Report for Colorectal Cancer,' which was developed by the Gastrointestinal Pathology Study Group (GIP) of the Korean Society of Pathologists, was published 13 years ago. Meanwhile, there have been many changes in the pathologic diagnosis of colorectal cancer (CRC), pathologic findings included in the pathology report, and immunohistochemical and molecular pathology required for the diagnosis and treatment of colorectal cancer. In order to reflect these changes, we (GIP) decided to make the second edition of the report. The purpose of this standardized pathology report is to provide a practical protocol for Korean pathologists, which could help diagnose and treat CRC patients. This report consists of "standard data elements" and "conditional data elements." Basic pathologic findings and parts necessary for prognostication of CRC patients are classified as "standard data elements," while other prognostic factors and factors related to adjuvant therapy are classified as "conditional data elements" so that each institution could select the contents according to the characteristics of the institution. The Korean version is also provided separately so that Korean pathologists can easily understand and use this report. We hope that this report will be helpful in the daily practice of CRC diagnosis.

Key Words: Colorectal neoplasms; Pathology report; Standardization; Protocol

Received: August 17, 2019 Revised: September 24, 2019 Accepted: September 26, 2019

Corresponding Author: Joon Mee Kim, MD, PhD, Department of Pathology, Inha University School of Medicine, 27 Inhang-ro, Jung-gu, Incheon 22332, Korea Tel: +82-32-890-3987, Fax: +82-32-890-3464, E-mail: jmkpath@inha.ac.kr

The first edition of the 'Standardized Pathology Report for Colorectal Cancer' was developed by the Gastrointestinal Pathology Study Group of the Korean Society of Pathologists and published in the Korean Journal of Pathology (predecessor of the Journal of Pathology and Translational Medicine) in 2006 [1]. Colorectal cancer (CRC), which was the fourth most common cancer in Korea at the time, is now the second most common cancer in Korea. Meanwhile, there have been many changes in the pathologic diagnosis of CRC, such as the diagnostic criteria for carcinoma, and pathologic findings included in the pathology report $[1,2]$. Molecular pathology tests for CRC have also become necessary tests, as targeted therapy and immunotherapy were introduced into the treatment of CRC. The existing standardization report does not reflect the recent changes in colon cancer diagnosis.

There has been considerable demand for the revision of the 
standardized pathology report, which is used by many Korean pathologists. From September 2017 to October 2018, the committee for the revision of the report was organized, and after several discussions and meetings, the second edition of the 'Standardized Pathology Report for Colorectal Cancer' was completed. This new report is based on the previous report with reference to the College of American Pathologists (CAP) protocol, American Joint Committee on Cancer (AJCC) 8th edition, World Health Organization (WHO) classification of tumors of the digestive system 5th edition, and International Classification of Diseases for Oncology (ICD-O) [3-6].

The purpose of this standardized pathology report is to enable standardized diagnosis and treatment of CRC patients and, furthermore, to help select the same patient group and exchange information in multicenter clinical trials or international studies. It would be desirable to include all the latest findings up to now in this report, but this would lead to an increase in the workload of the pathologist. In the current medical system of Korea, increased workloads cannot be appropriately reflected in the medical fee, which may lead this report to be unpractical for Korean pathologists. Therefore, the basic pathologic findings and parts necessary for prognostication of CRC patients are classified as "standard data elements," and other prognostic factors and factors related to adjuvant therapy are classified as "conditional data elements" so that each institution can select the contents according to the characteristics of the institution. As with the first edition, we have written this in English for the internationalization of pathology reports. We also have restricted the use of abbreviations or numerical taxonomy so that we can keep track of future data elements even if the diagnostic criteria and classification methods change.

As The Korean Journal of Pathology has become an Englishlanguage journal named The Journal of Pathology and Translational Medicine, this report was written in English, but the Korean version is also provided separately so that Korean pathologists can easily understand and use this report (Supplementary Material 1).

\section{STANDARD DATA ELEMENTS FOR RESECTED COLORECTUM}

All report forms mentioned in this document are shown in Table 1. If there are two or more tumors, the data elements should be listed for each tumor, starting with the tumor that has the deepest level of invasion. 'Regional lymph node metastasis,' 'Associated findings,' and 'Separate lesions' are noted only in the deepest tumor.

\section{Histopathologic type of invasive carcinoma}

Histologic classification of tumors is based on WHO classification (5th edition) [5]. Although most CRCs are "adenocarcinoma, not otherwise specified (NOS)," if there are other histologic variants, it is recommended to mention them separately. This is because some histologic variants may be associated with specific molecular alteration or patient prognosis [5,7]. Representative histologic types of CRC described in WHO classification and AJCC 8th edition are shown in Table $1[4,5]$.

Mucinous adenocarcinoma and signet ring cell carcinoma can be diagnosed when extracellular mucins are over $50 \%$ of tumor areas and signet ring cells are over $50 \%$ of tumor component, respectively. At levels of $50 \%$ or less, it is recommended to describe the ratio of mucin or signet ring cells along with histologic type [5]. When patients received preoperative neo-adjuvant therapy, which may produce mucin, it is advisable to describe the diagnosis of the preoperative specimen [8]. Medullary carcinoma is a rare histologic type that requires differentiation from undifferentiated carcinoma and it is diagnosed when cancer cells appear as solid or sheet-like structures and lymphocytic infiltration is prominent with intraepithelial (tumor-infiltrating) lymphocytes and neutrophils [5,7]. Tumor cells of medullary carcinoma usually show abundant eosinophilic cytoplasm, vesicular nuclei, and prominent nucleoli [5]. Another rare histologic type, micropapillary adenocarcinoma, can be diagnosed when small tumor cell clusters are surrounded by empty spaces, resembling lymphatic or small vessel invasion [9-11]. Micropapillary adenocarcinoma has a high risk of lymph node metastasis and is frequently accompanied with poor prognostic factors such as lymphatic and vascular invasion [9-13]. However, CRC with pure micropapillary patterns are extremely rare and most micropapillary lesions coexist with another histologic type $[5,14]$. The WHO classification suggests that tumors consisting of $5 \%$ or more micropapillary component should be diagnosed as micropapillary adenocarcinoma [5]. However, the minimal proportion of micropapillary components required for the diagnosis of micropapillary adenocarcinoma is controversial, and our committee could not reach a consensus. Serrated adenocarcinoma is also a special subtype of CRC that is morphologically similar to serrated polyps and is characterized by neoplastic glands with prominent epithelial serrations, low nucleus-to-cytoplasm ratio, eosinophilic and abundant cytoplasm, and vesicular nuclei $[5,15,16]$. Although some studies have suggested diagnostic criteria for serrated adenocarcinoma [17], a consensus has not yet been reached. Adenosquamous carcinoma is diagnosed when an area of definite squamous differentiation is present in the tumor. Although the WHO classification sug- 
Table 1. Report form of pathologic diagnosis for resected coloectal cancer

\begin{tabular}{l}
\hline Standard data elements \\
\hline Specimen type \\
$\square$ Right hemicolectomy \\
$\square$ Transverse hemicolectomy \\
$\square$ Left hemicolectomy \\
$\square$ Anterior resection \\
$\square$ Low anterior resection \\
$\square$ Abdominoperineal resection \\
$\square$ Subtotal/total colectomy \\
$\square$ Total proctocolectomy \\
$\square$ Transanal excision \\
$\square$ Endoscopic mucosal resection \\
$\square$ Other: (specify:
\end{tabular}

Histopathologic type of invasive carcinoma

$\square$ Adenocarcinoma, NOS

$\square$ Low-grade (well differentiated and moderately differentiated)

$\square$ High-grade (poorly differentiated)

$\square$ Mucinous adenocarcinoma

$\square$ Signet ring cell carcinoma

$\square$ Medullary carcinoma

$\square$ Serrated adenocarcinoma

$\square$ Micropapillary adenocarcinoma

$\square$ Squamous cell (epidermoid) carcinoma (excluding upwardly spreading anal tumors)

$\square$ Adenosquamous carcinoma

$\square$ Small cell neuroendocrine carcinoma

$\square$ Large cell neuroendocrine carcinoma

$\checkmark$ Mixed neuroendocrine-non-neuroendocrine neoplasm

$\square$ Undifferentiated carcinoma

$\checkmark$ Other: (specify:

\section{Location}

$\square$ Cecum

$\square$ Ascending colon

$\square$ Hepatic flexure

$\square$ Transverse colon

$\square$ Splenic flexure

$\square$ Descending colon

$\square$ Sigmoid colon

$\square$ Rectosigmoid junction

$\square$ Rectum

$\square$ Other: (specify:

\section{Gross type}

$$
\begin{aligned}
& \square \text { Fungating/polypoid } \\
& \square \text { Ulcerofungating } \\
& \square \text { Ulceroinfiltrative } \\
& \square \text { Infiltrative } \\
& \square \text { Unclassifiable }
\end{aligned}
$$

\section{Tumor size}

$$
\ldots \times \ldots
$$

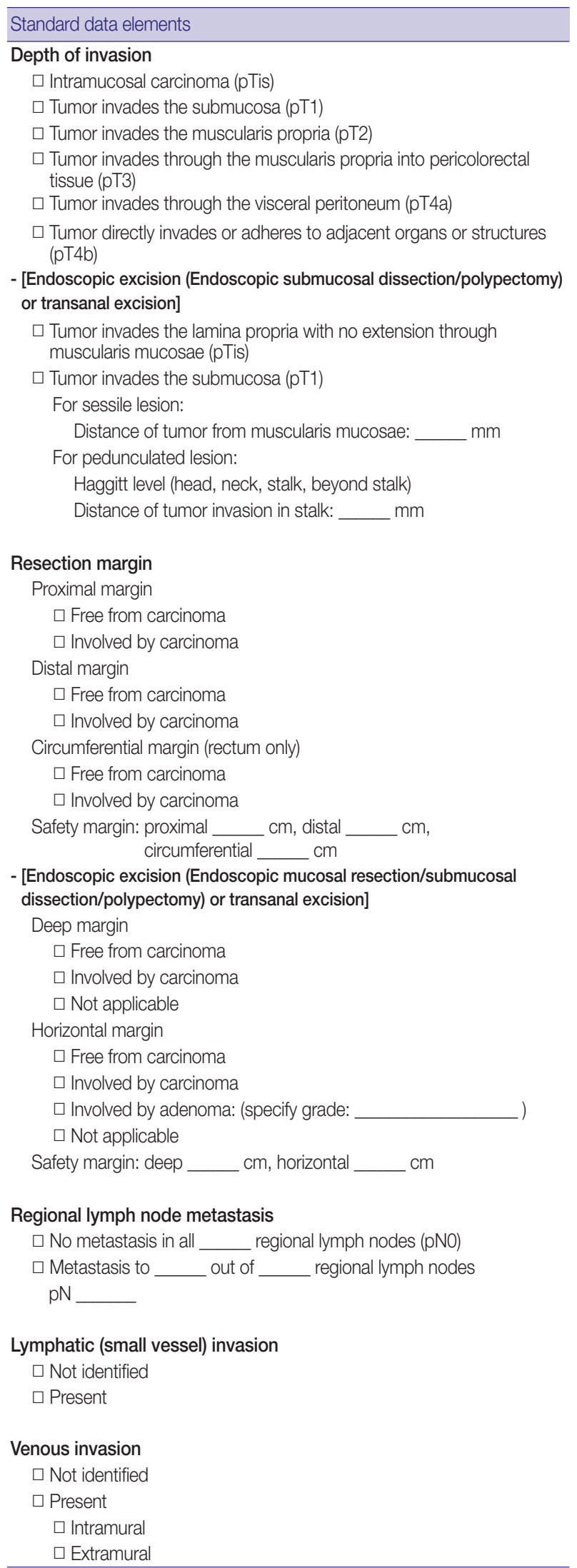

(Continued to the next page) 
Table 1. Continued

\begin{tabular}{l} 
Standard data elements \\
\hline Perineural invasion \\
$\square$ Not identified \\
$\square$ Present \\
Pre-existing adenoma \\
$\square$ Absent \\
$\square$ Tubular/Tubulovillous/Villous adenoma \\
$\quad$ Low grade dysplasia/High grade dysplasia \\
$\square$ Sessile serrated lesion (sessile serrated adenoma/polyp) \\
$\square$ Sessile serrated lesion (sessile serrated adenoma/polyp) with dysplasia \\
$\square$ Traditional serrated adenoma \\
$\square$ Other (specify: \\
Associated findings \\
$\square$ Absent \\
$\square$ Tumor perforation (pT4a) \\
$\square$ Perforation (non-tumor perforation) \\
$\square$ Metastasis to one site or organ without peritoneal metastasis (pM1a) \\
$\square$ Metastasis to two or more sites or organs without peritoneal \\
metastasis (pM1b) \\
$\square$ Metastasis to the peritoneal surface with or without other site or \\
organ metastasis (pM1c) \\
Specify metastatic sites or organs:
\end{tabular}

\section{Separate lesions}

$\square$ Absent

$\square$ Adenoma

$\square$ Polyp

$\square$ GIST

$\square$ Ulcerative colitis/Crohn's disease

$\square$ Others

Specify:

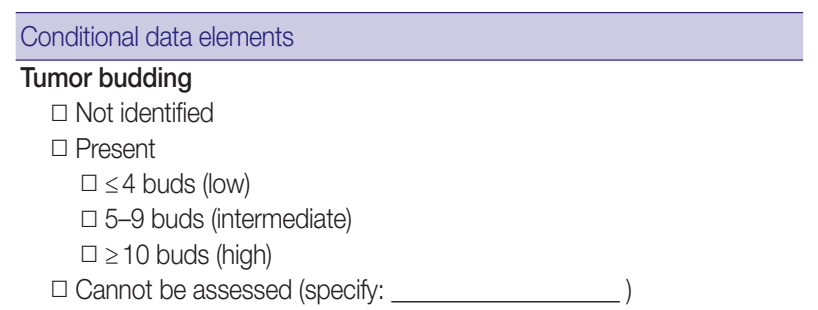

\section{Completeness of total mesorectal excision}

$\square$ Complete

$\square$ Nearly complete

$\square$ Incomplete

$\square$ Cannot be determined

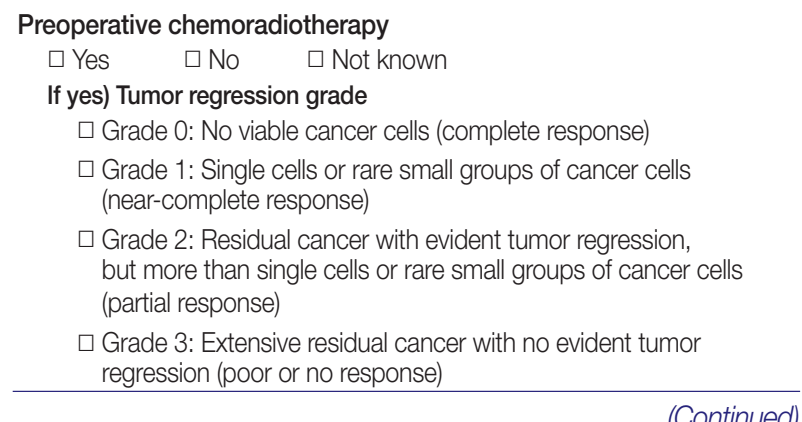

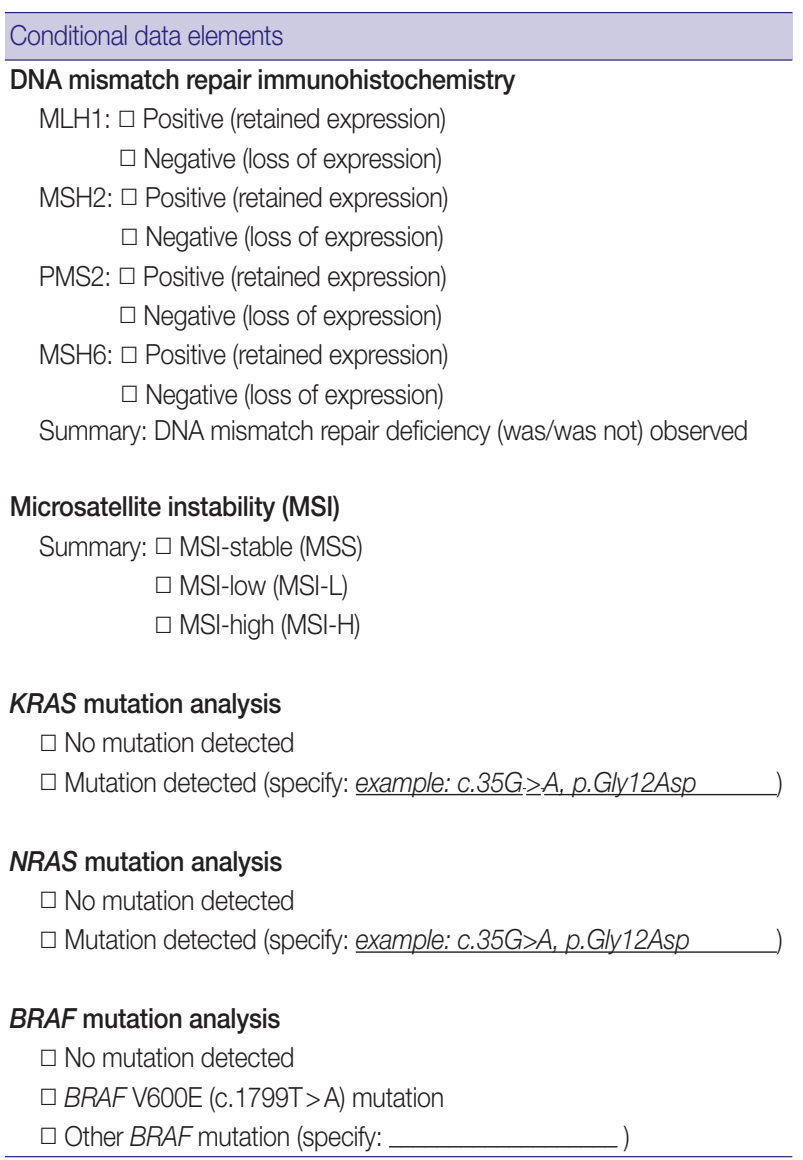

Comment: This report is intended to be applicable to endoscopic resection or transanal excision specimens as well as surgical resection of CRC.

NOS, not otherwise specified; CRC, colorectal cancer.

gests a greater than $20 \%$ and $25 \%$ adenocarcinoma component or squamous cell carcinoma component, respectively, for the diagnosis of adenosquamous carcinoma in esophageal and gastric cancer, respectively, there is no standardized diagnostic criteria for adenosquamous carcinoma in terms of the squamous cell carcinoma component [5]. We recommend diagnosing adenosquamous carcinoma when the squamous cell carcinoma component is clearly seen in "more than occasional small foci" as described in the previous report [1]. Undifferentiated carcinoma is diagnosed when the epithelial tumor lacks morphological, immunohistochemical, and molecular evidence of specific differentiation [5]. Adenoma-like adenocarcinoma, also called villous adenocarcinoma, was first introduced as a histological subtype of CRC in the WHO 5th edition [5]. Adenoma-like adenocarcinoma is composed of villous adenoma-like well differentiated tumors in the invasive portion, showing pushing border and minimal desmoplasia [5]. Whether adenoma-like adenocarcinoma should be classified as a specific subtype of CRC is still controversial and has not been added as a subtype in this report. 
Differentiation of tumors is determined by the area ratio of gland or tubule formation by tumor cells [7]. The degree of differentiation of the tumor is applicable to adenocarcinoma, NOS. This is because other histologic types show their own prognosis [7]. Recently, tumor differentiation has been shown to affect the prognosis of patients with mucinous adenocarcinoma $[5,18]$. However, standardized tumor grading of mucinous adenocarcinoma has not been presented yet. Tumor grading is preferably performed using a two-tiered system with low-grade and highgrade [5]. In the 3-tiered grading system, tumor differentiation is graded as well differentiated (>95\% gland formation), moderately differentiated (50\%-95\% gland formation), or poorly differentiated ( $<50 \%$ gland formation). The "well- and moderately differentiated" grades correspond to low-grade, while "poorly differentiated" corresponds to high-grade of the two-tiered grading system [5,19].

\section{Location}

The location of the tumor follows the ICD-O classification [6]. The length of the cecum is approximately $6 \mathrm{~cm}$ and the length of the sigmoid colon is approximately $40 \mathrm{~cm}$. The rectum begins at $1-2 \mathrm{~cm}$ above the dentate line and is $12-15 \mathrm{~cm}$ long. The upper third of the rectum is covered by peritoneum on the anterior and lateral sides, the middle third is covered by peritoneum on the anterior side, and the lower third is not covered by peritoneum. In this revision, "overlapping lesion of the colon" was removed from the tumor location section because it is practically not used in most institutions. When tumors are involved in two locations of the colon, the tumor epicenter and more involved area should be considered in the determination of tumor location.

\section{Gross type}

Superficial type is not recommended for describing tumor gross morphology, because superficial type could be defined by microscopic examination. Fungating/polypoid type can substitute most gross morphology of the previously established superficial type. Nevertheless, if superficial type is used, it should be applied to tumors that are confined to mucosa or submucosa and with tumor thickness of no more than two-fold thickness of adjacent mucosa. Other criteria for tumor gross types are the same as in the previous version. Fungating/polypoid, ulcerofungating, ulceroinfiltrative, and infiltrative gross types correspond to the Borrmann classification of gastric cancer.

\section{Tumor size}

The tumor size is expressed as the product of the longest axis and the length perpendicular to it. The depth of the tumor is measured with a microscope at the thickest point.

\section{Depth of invasion}

According to the AJCC 8th edition, "intraepithelial carcinoma" that is confined to the crypt epithelium and lacks invasion beyond the basement membrane is considered synonymous to high-grade dysplasia and is excluded from the pTis category. Intramucosal carcinoma that shows invasion into lamina propria with no penetration through the muscularis mucosae into the submucosa is assigned to pTis considering the negligible risk for metastasis [4]. The histopathologic features of intramucosal carcinoma are defined as follows: (1) infiltration of the stroma by either single or small clusters of tumor cells with basement membrane disruption; (2) a stromal response such as desmoplasia or inflammatory cell infiltrates around the invasion front; (3) definite nuclear anaplasia and severe glandular structural abnormality including marked glandular crowding or excessive branching and budding that endows high suspicion of basement membrane destruction (Fig. 1A, B) [20]. In comparison, highgrade dysplasia is diagnosed when the tumor gland shows (1) nuclear pleomorphism with loss of polarity, (2) architectural complexity of intraluminal cribriforming or necrosis, and (3) back-toback fusion of multiple glands without lamina propria invasion. Low-grade dysplasia is used when the pseudostratified nucleus is seen without complex architectural change of the glands, regardless of the nuclear ratio to the cell length (Fig. 1C) (refer to 'Preexisting adenoma'). However, intraepithelial carcinoma of the colorectum had been classified as pTis in the AJCC 7th or earlier editions, while intraepithelial carcinoma of other gastrointestinal tracts except the colorectum is still diagnosed as pTis [4]. Therefore, we recommend minimizing the use of intraepithelial carcinoma or adenocarcinoma in situ in order to reduce confusion and suggest using high-grade dysplasia or intramucosal carcinoma for the diagnosis of mucosal high-grade lesions.

If there is a tumor at the site where the proper muscle has disappeared by ulceration, it is defined as subserosal infiltration of the tumor (pT3). If tumor cells approach the serosal surface by a gap of $\leq 1 \mathrm{~mm}$ with a fibroinflammatory reaction, scrupulous examinations using deeper sections and/or additional tissue blocks are needed to uncover serosal surface involvement $[4,21]$. In colorectal tumors, similar to other gastrointestinal organs, pT4 is subcategorized into pT4a and pT4b. Although pT4a is basically defined as direct involvement of the serosal surface (visceral peri- 

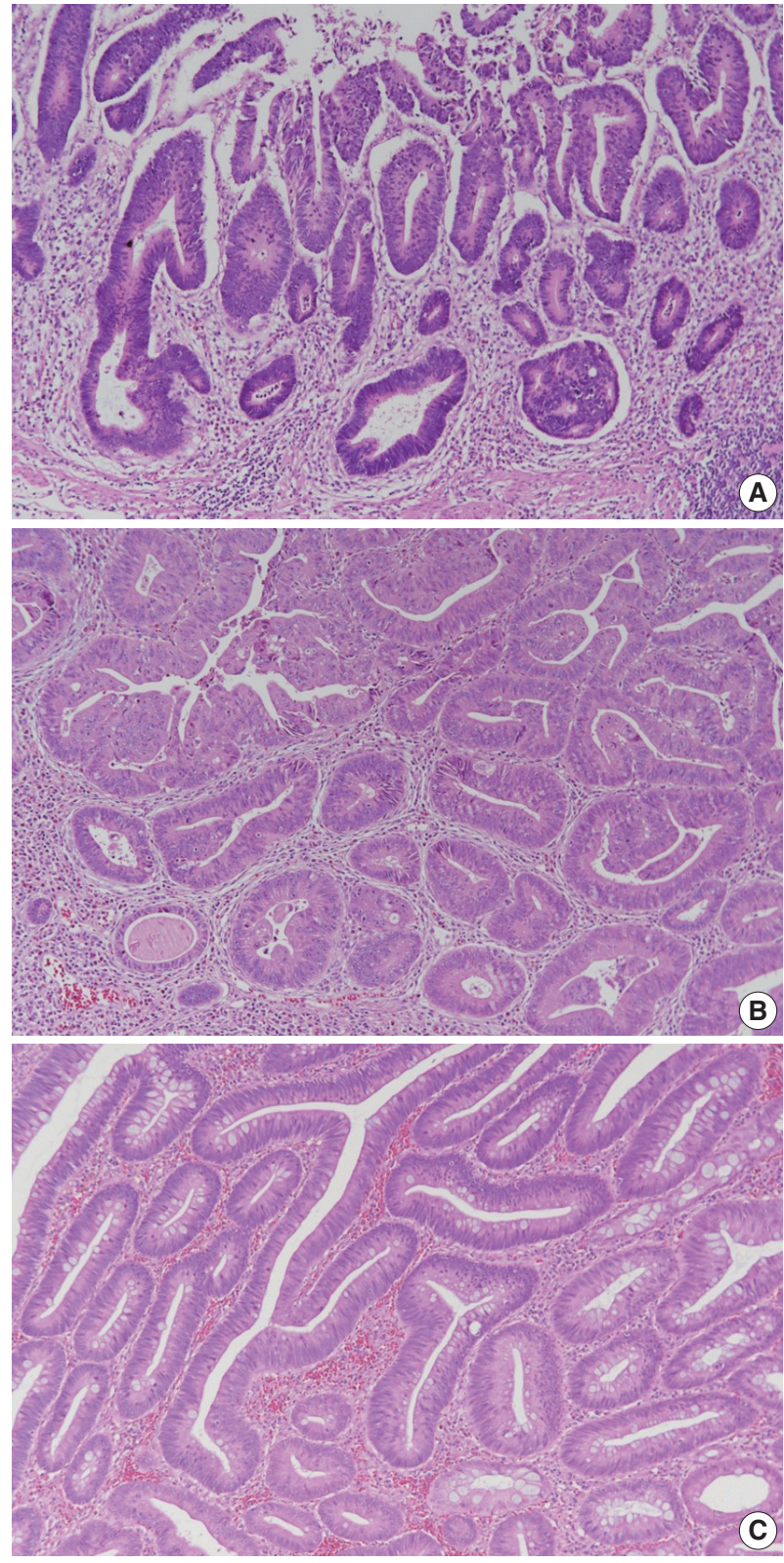

Fig. 1. Histologic features of intramucosal carcinoma. (A) The intramucosal carcinoma shows irregular invasive glands accompanied by desmoplasia. (B) The glands show excessive budding and luminal serration, which is highly suspicious for disruption of the basement membrane. (C) The elongated nuclei are seen in lowgrade dysplasia, regardless of the ratio to the cell length.

toneum) by tumor invasion, pT4a encompasses the cases in which tumors with perforation display carcinoma cells running through inflammation to the serosal surface and are accompanied by mesothelial proliferation. The pT4a category is not applicable in nonperitonealized portions of the colorectum, including posterior aspects of the ascending and descending colon and lower portion of the rectum. The pT $4 \mathrm{~b}$ category is assigned when the tumor directly invades the adjacent organs or structures. For distal rectal tumors, tumors with involvement of the external sphincter are assigned to $\mathrm{pT} 3$, whereas those with the involvement of the levator ani muscle are assigned to pT4b.

The presence of tumor cells within the lymphatic or venous vessels is not considered when determining the depth of invasion. The presence of vascular invasion should be recorded in parentheses separately (e.g., invades proper muscle [involvement of subserosa by lymphatic emboli]). The skip metastasis of multiple lesions in mucosa or submucosa of the adjacent bowel is not classified as distant metastasis. The presence of a peritumoral abscess or acellular mucin pool in cancers with preoperative chemoradiotherapy has been known to be unrelated to patients' prognosis in CRC, and also is not considered in determining the depth of invasion [22-24].

\section{Endoscopic excision (endoscopic submucosal dissection/ polypectomy) or transanal excision}

Invasive adenocarcinomas arising in colorectal adenomas have been called "malignant polyps," in which tumor cells penetrate through the muscularis mucosae into the submucosa. Independent prognostic factors that prompt further surgical treatment of endoscopically resected polyps are as follows: (1) poorly differentiated carcinoma, (2) tumors at or less than $1 \mathrm{~mm}$ from the resection margin, and (3) presence of lymphatic and/or venous vessel involvement. Submucosal invasion depth is also an important factor in determining subsequent surgical treatment, since a submucosal invasion depth of $\geq 1,000 \mu \mathrm{m}$ in malignant polyps of sessile (non-pedunculated) morphology indicates a significantly increased risk for lymph node metastasis [25,26].

In this committee, measurement methods were discussed to reduce measurement error in submucosal invasion depth. Polyps are classified into pedunculated and nonpedunculated polyps. For pedunculated polyps, submucosal invasion is classified as 'head,' 'neck,' 'stalk,' and 'beyond stalk' according to the Haggitt classification, in which the neck of the polyp (level 2) is the reference point for measuring stalk invasion (Fig. 2A, B) [27,28]. In nonpedunculated polyps, when the muscularis mucosae is preserved, submucosal invasion depth is measured vertically from the lowest part of the muscularis mucosae. When the muscularis mucosae has been disrupted or has disappeared, the depth of submucosa invasion is measured from the imaginary line that is continuous from the residual muscularis mucosae of the neighboring mucosa (Fig. 2C, D) [29]. 

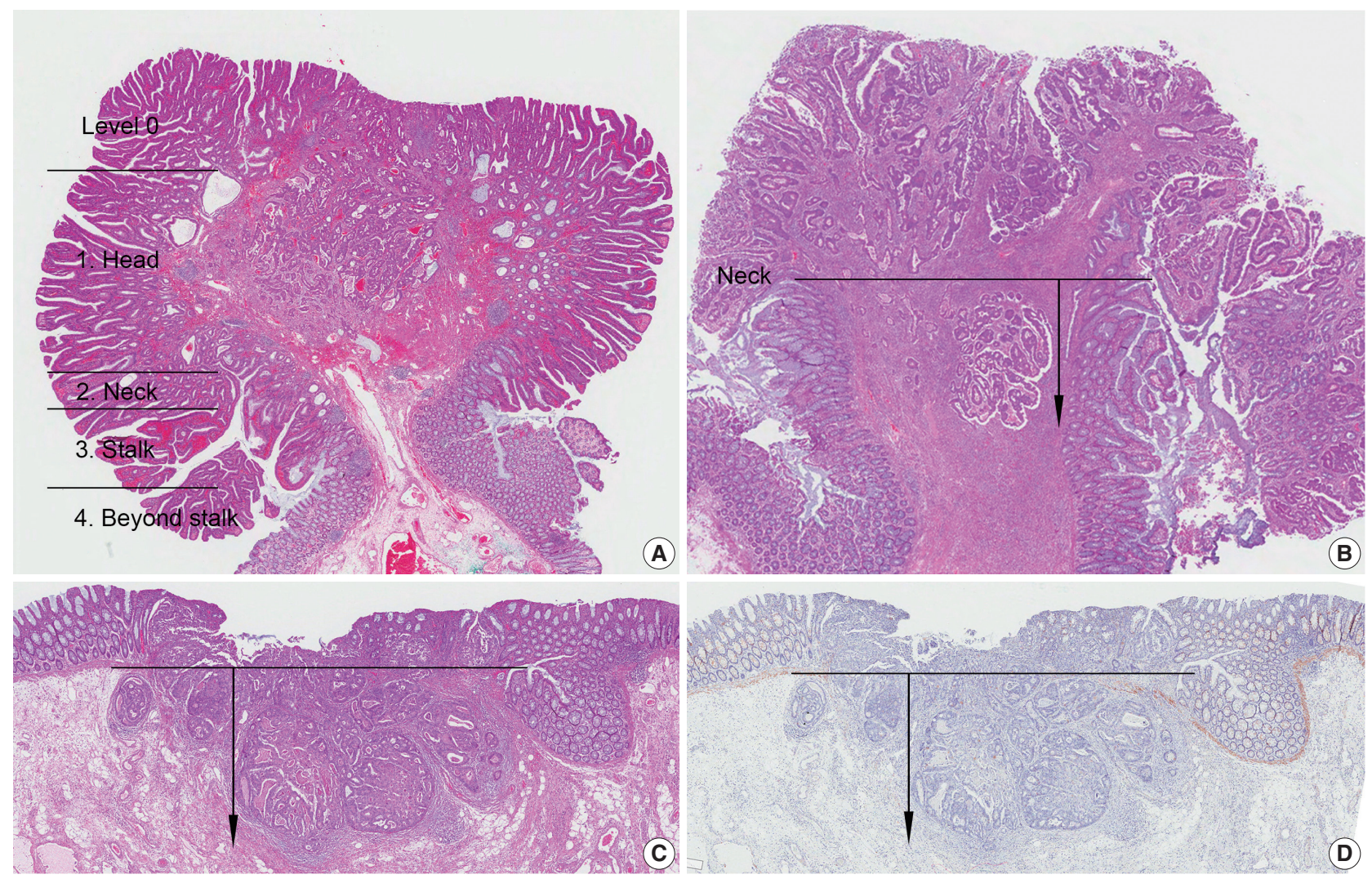

Fig. 2. Measuring depth of invasion in tumors with submucosal invasion. (A) Haggitt level of invasion is composed of head, neck, stalk, and beyond stalk in pedunculated tumors. (B) The depth of invasion should be measured from the neck of the polyp (Haggitt level 2). (C) In cases with disrupted muscularis mucosae, the depth of submucosa invasion is measured from a continuous line of the residual muscularis mucosae. (D) To highlight indistinct muscularis mucosae, immunohistochemistry for desmin may be performed.

\section{Resection margin}

The distance from the proximal and distal resection margins is the length from the edge of the carcinoma to the nearest resection margin. In rectal cancer, the circumferential resection margin should be measured in the areas uncovered by peritoneum. After confirming the circumferential resection margin of the resected specimen, mark the margin with ink, and obtain sections including the site where the tumor is most deeply infiltrated. The involvement of carcinoma in the margin is finally assessed by microscopic examination. If the distance between circumferential resection margin and carcinoma (including lymph node, neural invasion, and intravascular tumor emboli) is $0.1 \mathrm{~cm}$ or less than $0.1 \mathrm{~cm}$, the resection margin is regarded as positive [3,4]. Circumferential margins of colon cancers other than rectal cancers can be reported when necessary.

\section{Endoscopic excision (endoscopic mucosal resection/} submucosal dissection/polypectomy) or transanal excision

This form is applied to the endoscopic resection (polypectomy, mucosal resection, and submucosal dissection) and trans-anal resection. The deep and horizontal margins are examined microscopically. Margin involvement by adenoma is reported in the horizontal margin. When it is impossible to evaluate the resection margins, such as in specimen fragmentation, it shall be marked as 'not applicable.'

\section{Regional lymph node metastasis}

Diagnosis of regional lymph node metastasis is made according to the AJCC 8th edition [4]. Although it is recommended to examine 12 or more lymph nodes for determination of accurate prognosis, pN0 can be used if fewer lymph nodes are available, but no lymph node metastasis is observed. Preoperative chemotherapy and radiotherapy can cause fewer lymph nodes to be harvested. Metastasis to lymph nodes other than regional lymph nodes should be diagnosed as distant metastasis and should not be included in lymph node metastasis numbers.

If the size of the metastatic tumor is less than $2 \mathrm{~mm}$ and more than $0.2 \mathrm{~mm}$, it is classified as micrometastasis. If it is less than 
$0.2 \mathrm{~mm}$, it is classified as isolated tumor cell [4]. A lymph node with micrometastasis is counted as a metastatic lymph node. Although isolated tumor cells are known to be associated with poor prognosis in some stages, $\mathrm{pNO}$ is recommended in AJCC [4]. However, this is controversial and difficult to apply in routine pathologic diagnosis. Thus, we recommend that isolated tumor cells found on hematoxylin and eosin (H\&E) slides are considered to be lymph node metastasis and included in the metastatic lymph node numbers, as in the first edition of this report [1].

Tumor deposits are tumor nodules observed separately from the primary tumor in the subserosa, mesentery, and perirectal tissues, regardless of size, shape, and border. Lymph node, vessel, and neural invasions are excluded from tumor deposits [4]. If a blood vessel or nerve structure is observed within the tumor nodule, it should be regarded as a blood vessel invasion or a neural invasion. Elastic stain or immunohistochemical stain (IHC), such as smooth muscle actin, may be helpful in differentiating tumor deposits. pN1c is used when there is no lymph node metastasis, regardless of the invasion depth of the primary tumor, and when there is a tumor deposit. If there are metastatic lymph nodes, tumor deposits are not included in the number of positive lymph nodes. Care should be taken if the patient received preoperative therapy, because regressed residual tumor in subserosa or perirectal soft tissue can be seen as a tumor deposit.

\section{Lymphatic (small vessel) invasion and venous invasion}

Identification of lymphatic invasion by the tumor has been recognized as a predictor of lymph node metastasis [26], and identification of venous invasion is a well-known independent prognostic indicator [30]. IHC for D2-40 may be performed additionally to identify endothelial cells because it can be difficult to differentiate the lymphatic vessel from retraction artifacts on H\&E sections (Fig. 3A). It is commonly difficult to distinguish lymphatic vessels from blood vessels on H\&E sections. Thus, it is considered as lymphatic (small vessel) invasion when the tumor cells involve small vessels, such as lymphatics, capillaries, and postcapillary venules (Fig. 3B), whereas venous invasion is when the tumor cells involve large vessels with an identifiable smooth muscle layer or elastic lamina (Fig. 3C) [31]. This should be considered lymphatic (small vessel) invasion if the size of the involved vessel corresponds to that of small vessel, even though there are red blood cells in the involved vessel. Additionally, special stains for elastic fiber or IHCs for CD31, D2-40, and smooth muscle actin can be used if necessary. It is recommended extramural venous invasion be reported separately from the intramural venous invasion, because the former is an adverse prognostic factor
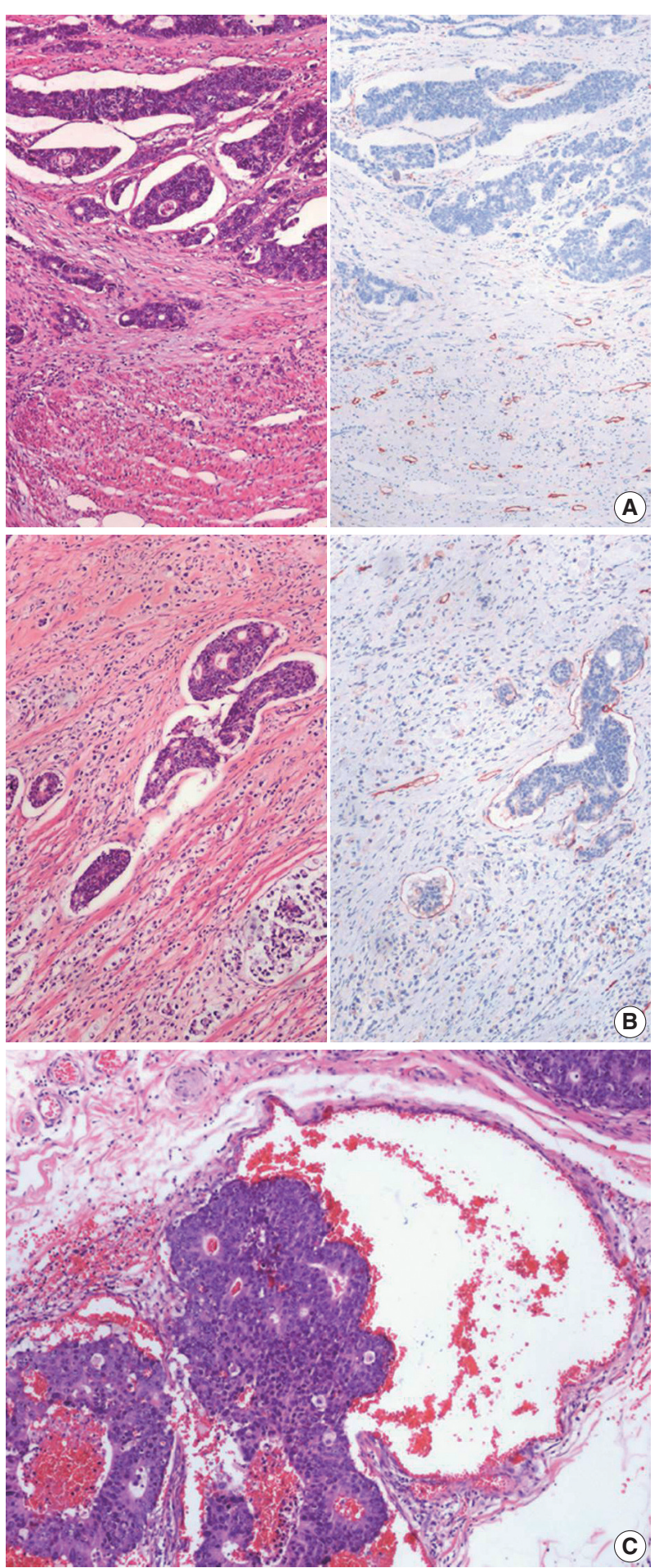

Fig. 3. Histologic features of lymphatic invasion and venous invasion. (A) Tumor clusters with retraction artifacts can be misinterpreted as lymphatic invasion (H\&E stain and D2-40 immunohistochemical stain). (B) Tumor invasion of small vessels is considered as lymphatic invasion (H\&E stain and D2-40 immunohistochemical stain). (C) Tumors involving vessels with identifiable smooth muscle layer or elastic lamina are considered as venous invasion. 
and an independent risk factor for liver metastasis [30].

\section{Perineural invasion}

Perineural invasion has been known as an independent predictor of poor prognosis in CRC [32]. Perineural invasion is an essential element of the pathologic report for CRC and it can be assessed on routine $\mathrm{H} \& \mathrm{E}$ sections. Although there is no clear definition of perineural invasion, it is considered as perineural invasion when the tumor cells invade any of the three layers of nerve sheath, around the nerve, as well as into the nerve [33].

\section{Pre-existing adenoma}

Two major categories of CRC precursor lesions include conventional adenomas and serrated lesions [34]. According to the latest WHO classification of tumors of the digestive system, conventional adenomas are morphologically classified into tubular (villous component $<25 \%$ ), tubulovillous (villous component $25 \%$ $75 \%$ ), or villous (villous component $>75 \%$ ) adenomas based on the proportion of tubular and villous architectures in an adenoma [5]. By definition, all conventional adenomas show dysplastic epithelium, and dysplasia in conventional adenomas can be graded as low-grade or high-grade [5]. High-grade dysplasia is characterized by architectural complexities (e.g., intraluminal cribriforming or necrosis, or back-to-back fusion of multiple glands), nuclear pleomorphisms, loss of nuclear polarity, and increased nuclear-to-cytoplasmic ratio (Fig. 4A). Features of low-grade dysplasia include non-complex architecture, pseudostratified/ elongated nuclei with hyperchromasia, and preserved cellular polarization (Fig. 4B). The most important part of the distinction between high-grade and low-grade dysplasia is a complex glandular structure formation of tumor glands without invasion of lamina propria. Dysplastic glands only showing cytologic atypia without complex structural change are not diagnosed as highgrade dysplasia. In the previous edition, we recommended the diagnosis of high-grade dysplasia when there are three contiguous dysplastic gland structures showing high-grade features, which include cytologic atypia. According to the previous edition, there was a tendency to diagnose high-grade dysplasia with only focal cytologic atypia, but tumors with glandular structural abnormalities were sometimes missed as low-grade dysplasia. So, in this edition, complex structural abnormality is described as an essential part of the diagnosis of high-grade dysplasia. When high-grade and low-grade dysplasia components are mixed in a conventional adenoma, the adenoma should be diagnosed as high-grade dysplasia [1].

Serrated lesions include hyperplastic polyps (HPs), sessile ser- rated lesions (SSLs, formerly called sessile serrated adenoma/polyp), and traditional serrated adenomas (TSAs), according to the latest WHO classification [5]. However, the classification and diagnostic criteria of serrated lesions have continuously changed [35,36]. Based on a comprehensive review of the latest WHO classification (2019) [5], expert panel recommendations from the US (2012) [35], and UK guidance (2015) [36], we recommend the use of three diagnostic terms for serrated lesions as pre-existing adenomas in CRC: SSL, SSL with dysplasia (SSLD), and TSA. Because HP is regarded as a benign, non-precancerous lesion, it is excluded from serrated lesions as a pre-existing adenoma of CRC.

All SSLs are regarded as premalignant lesions, and morphologic dysplasia in SSLs can be present or absent. In comparison to SSL without dysplasia, SSLD is regarded to have a higher risk of progression into carcinoma. SSL is morphologically characterized by crypt luminal serrations extending to the crypt base, horizontal growth of the crypt, and asymmetrical proliferation with typical dilated/branching bases of crypts (Fig 4C). The diagnosis of SSL can be made when there is at least one typical architecturally distorted crypt [5,35]. Morphologic changes in SSLD can be diverse, and multiple morphologic patterns can be seen in a single lesion. Structural changes in SSLD include villous change, elongation of crypts, crowding of crypts, cribriform formation, and excessive decrease of luminal serration. Cytologically, dysplastic cells can show conventional adenoma-like dysplasia (so-called intestinal dysplasia) or round atypical nuclei with prominent nucleoli (serrated dysplasia) [5]. Loss of MLH1 expression is frequently found in SSLD and MLH1 immunohistochemical staining may help to define dysplasia [37]. However, the grading system for SSLD has not been suggested yet. Therefore, we simply recommend the presence or absence of dysplasia, regardless of dysplasia subtype or grade, for the description of SSL as a pre-existing adenoma of CRC.

All TSAs are regarded as precancerous dysplastic lesions, although classification or grading systems for dysplasia in TSAs have not been established. Thus, we recommend the term TSA without any description of dysplasia as a pre-existing adenoma of CRC. TSA is morphologically characterized by broad-topped, sharplyinvaginated luminal serration, tall columnar cells with abundant eosinophilic cytoplasm, pencillate nuclei, and ectopic crypt formation (Fig. 4D). TSAs can frequently be found as mixed lesions accompanying other serrated lesions or conventional adenomas $[37,38]$.

In the case of a premalignant lesion consisting of two or more different histologic types of conventional adenomas and/or serrated lesions, the lesion can be referred to as a mixed adenoma. 

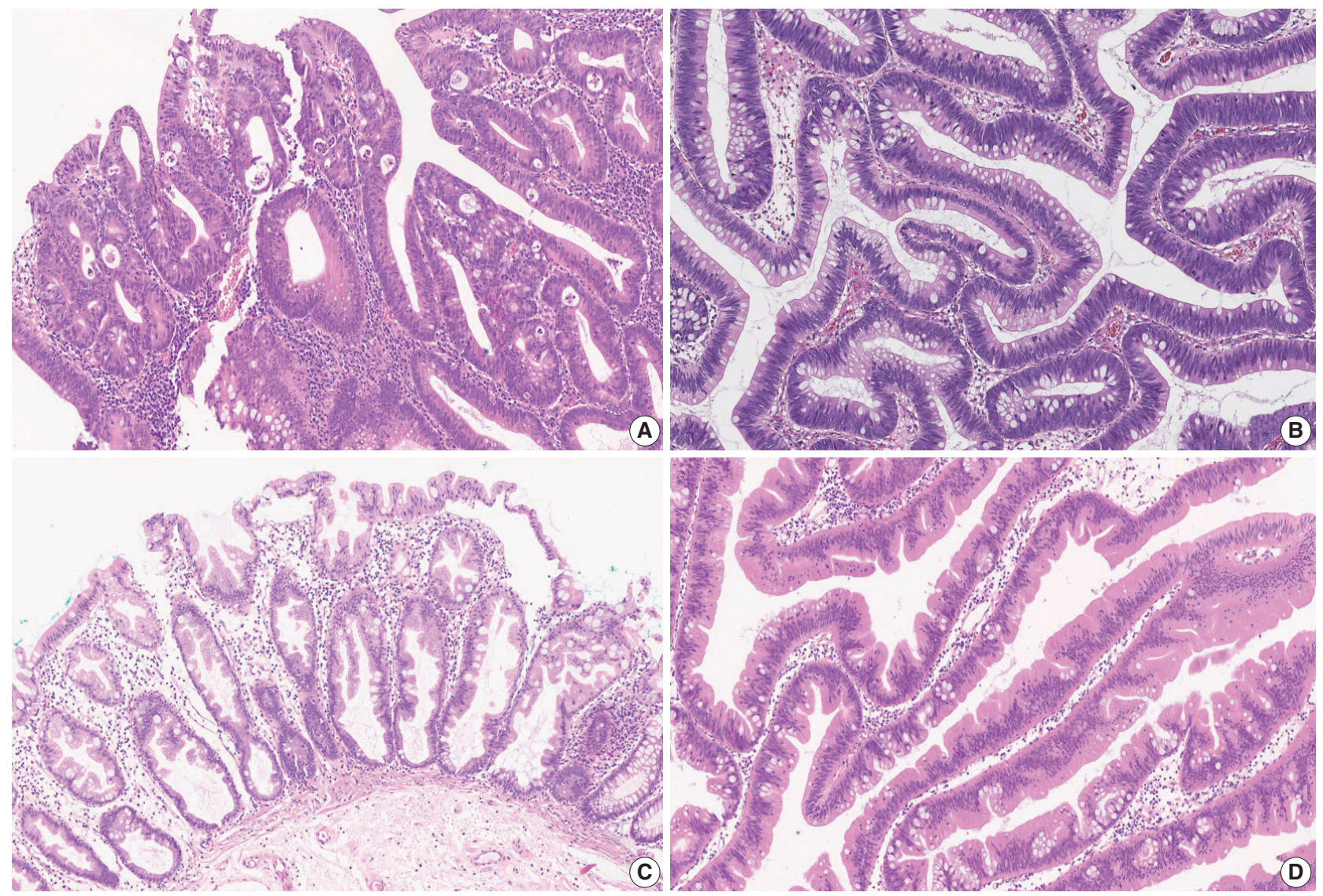

Fig. 4. Histologic features of premalignant lesions of the colorectum. (A) Tubular adenoma with high-grade dysplasia. Note the architectural complexity including cribriform pattern or back-to-back fusion of dysplastic glands. (B) Tubulovillous adenoma with low-grade dysplasia. Note the retained cellular polarity with pseudostratified, elongated nuclei. (C) Sessile serrated adenoma without dysplasia. Note the dilated base of crypts. (D) Traditional serrated adenoma. Note the deep-invaginated pattern of crypt serration with hypereosinophilic cytoplasm and pencillated nuclei.

\section{Associated findings}

Tumor perforation is associated with a poor outcome in CRC [39]. It is known that perforation of the uninvolved colon proximal to an obstructing tumor can cause peritonitis or sepsis, and is associated with poor prognosis. Distant metastasis is now divided into metastasis to one site or organ (pMla), or metastasis to two or more sites or organs (pM1b), in the absence of peritoneal surface metastasis according to the AJCC 8th edition. Peritoneal surface metastasis is classified as pM1c [4].

\section{Separate lesions}

When there are lesions other than colorectal cancer, such as separate adenomas, polyps, gastrointestinal stromal tumors, or inflammatory bowel disease, they can be denoted in this section.

\section{CONDITIONAL DATA ELEMENTS FOR RESECTED COLORECTUM}

\section{Tumor budding}

Tumor budding is a well-known independent adverse prognostic factor of CRC [40]. Tumor budding components in the pathologic report can be potentially helpful in the decisionmaking process for the management of patients with CRC. First, in patients presenting with endoscopically resected submucosal invasive CRC, the presence of tumor budding is positively correlated with increased risk of lymph node metastases $[26,41,42]$. Therefore, patients with tumor budding can be potential surgical candidates. Second, stage II CRC patients with high-grade tumor budding show worse disease-free survival than those with no or low-grade tumor budding. Therefore, high-grade tumor budding may be useful for screening patients who need adjuvant therapy [43]. Finally, the presence of tumor budding in pre-operative bi- 
opsies can aid in the selection of high-risk rectal cancer patients for neoadjuvant therapy $[44,45]$. As mentioned above, in endoscopically resected pT1 CRC patients and stage II CRC patients, it is recommended to include tumor budding in the pathologic report.

The International Tumor Budding Consensus Conference (ITBCC) held in 2016 has recommended the following criteria for evaluation of tumor budding [46]. (1) Tumor budding is defined as a single tumor cell or a cell cluster containing $\leq 4$ tumor cells. (2) Tumor budding should be assessed in the hotspot at the invasive tumor front (in a field measuring $0.785 \mathrm{~mm}^{2}$, which corresponds to a $20 \times$ objective lens with an eyepiece having a field number that is $20 \mathrm{~mm}$ in diameter) chosen after a review of the available slides. (3) Tumor budding can be assessed on H\&E slides. IHC for keratin can be helpful in evaluation of obscure cases showing a peritumoral inflammatory infiltrate on H\&E-stained slides, which is difficult to distinguish from reactive stromal cells. In such cases, IHC enables better visualization of tumor budding and superior reproducibility and inter-observer agreement [47]. However, keratin also stains apoptotic bodies and cellular debris, which should not be misinterpreted as tumor budding $[46,48]$.

We also recommend a 3-tier grading system for reporting of tumor budding. However, this grading system is not an absolute standard. Measuring and reporting the number of tumor buddings could be more beneficial to avoid any loss of information that may occur when applying a cut-off value in borderline cases. In rare histopathological subtypes, such as mucinous, signet-ring cells, micropapillary, and medullary carcinomas, the evaluation of tumor budding should be performed with caution [46]. Therefore, when tumor budding cannot be accurately assessed, it is recommended that the findings be reported as "cannot be assessed" with an explanatory note added to the report.

\section{Tumor border configuration}

Regarding tumor border configuration, there is currently no recommendation in the AJCC 8th edition, nor in the CAP protocol for CRC, and only a brief mention in the WHO classification [3-5]. Although the assessment of tumor border configuration can be easily carried out using H\&E slides, inter-observer reproducibility is lacking due to ambiguous definitions [49]. For these reasons, the tumor border configuration was excluded from this standardization report.

\section{Completeness of total mesorectal excision}

Total mesorectal excision is a surgical technique that dissects within the areolar plane outside the visceral mesorectal fascia to remove rectum [50]. A large number of non-randomized studies have shown that if total mesorectal excision is appropriately performed, then adequate resection margin is secured, and local recurrence rate is reduced. The surface of the fresh rectal specimen is examined circumferentially, and the completeness of the mesorectal excision is scored according to the worst area, as below $[3,4,7]$.

- Complete: Mesorectum is totally resected. The surface of the specimen is smooth and there is no coning towards the distal margin (there is no surface defect greater than $0.5 \mathrm{~cm}$ in depth).

- Nearly complete: There is irregularity of the mesorectal surface. The surface defect is greater than $0.5 \mathrm{~cm}$, but proper muscle layer is not exposed (except for levator ani muscles).

- Incomplete: Severe mesorectal defects down to the muscularis propria. Muscularis propria is exposed.

\section{Preoperative chemoradiotherapy}

Preoperative chemoradiotherapy (CRT) followed by curative resection with TME has been established as a standard treatment for patients with locally advanced rectal cancer [51,52]. Tumor regression after preoperative CRT has an important role that can improve patient outcomes and the potential for achieving no residual tumor status [53-55]. Many studies have been performed to perceive a practical and applicable tumor regression grading (TRG) system [4,53-59]. The tumor regression after CRT was assessed only in the primary tumor and the nodal status was not included in the assessment of the TRG system [4]. The TRG system recommended in the previous edition of the "standardized pathology report for colorectal cancer" used a descriptive 5-tier system and can be easily translated into the Mandard and Dworak TRG scoring system [1]. However, even with a descriptive TRG system there is an inter-observer variation between pathologists, and this descriptive TRG system is not widely used and is often confused with other existing TRG systems. To overcome this, we suggest a new TRG system, which can be widely used in the pathologic practice, based on the AJCC 8th edition and CAP cancer protocol (Fig. 5) [3,4].

The number of blocks taken is dependent on the size of the residual tumor. If the tumor is grossly visible, a minimum of 4 paraffin blocks should be taken from the tumor, including samples from its closest point to the nearest margin. However, if the tumor is ill-defined and impossible to distinguish from fibrous stromal tissue or the tumor bed size is less than $2.0 \mathrm{~cm}$, the entire embedding of the macroscopically identifiable tumor bed or entire scar area is recommended, orientated from proximal to distal in 0.4-cm levels. Careful examination of the residual tumor cells is essential and is mandatory for assessment of complete response 

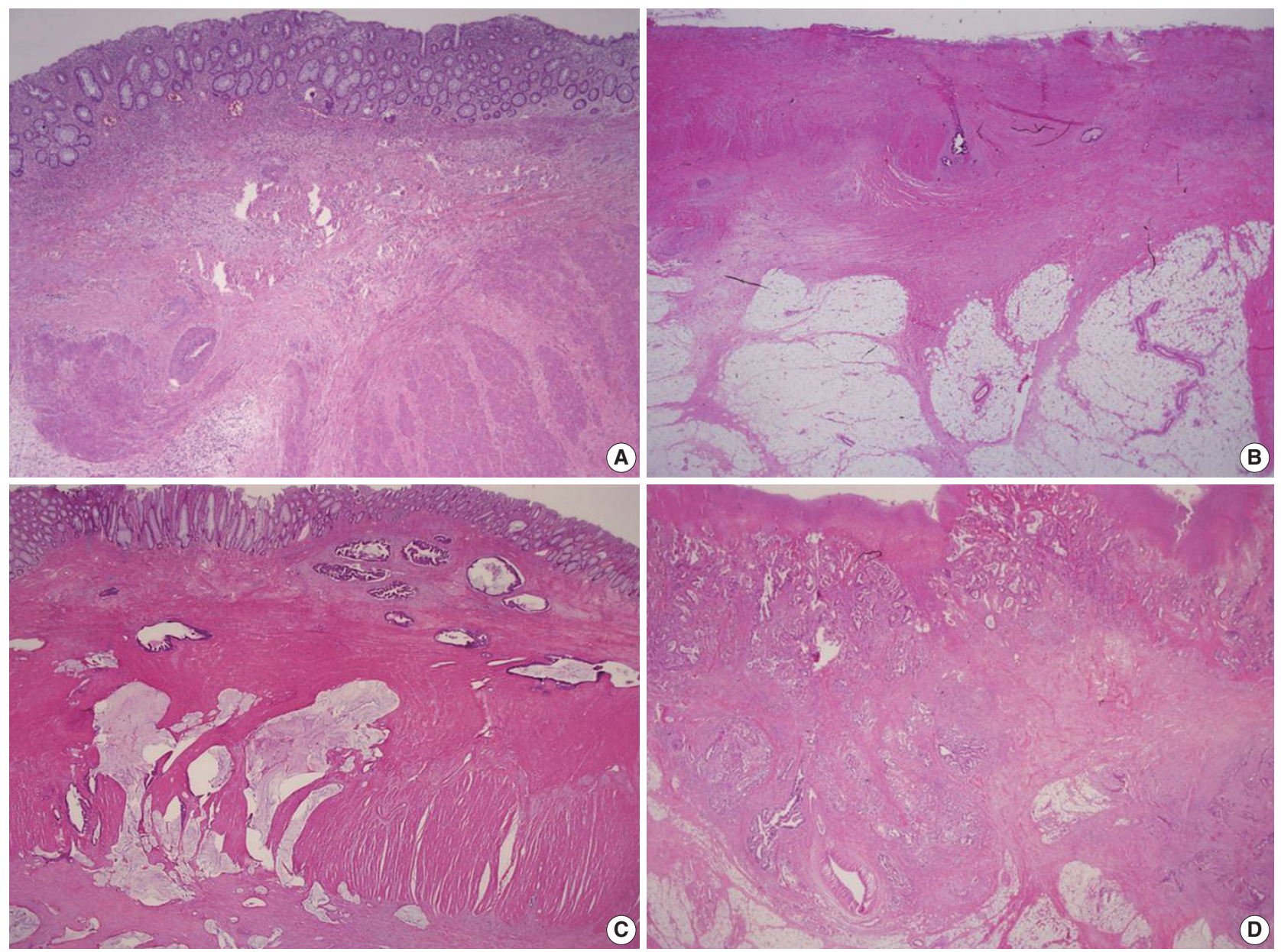

Fig. 5. Recommended tumor regression grading system. (A) Grade 0, complete response. No residual tumor cells are identified. (B) Grade 1, near complete response. The tumor bed contained abundant fibrosis with only a few or scattered tumor cells. (C) Grade 2, partial response. Residual tumor glands are easily identified in tumor bed. (D) Grade 3, poor or no response. The tumor cells do not demonstrate any response to chemoradiotherapy because abundant residual adenocarcinoma is present.

after CRT in CRC patients. Histologically, the tumor bed is characterized by abundant fibrotic stroma with a moderate number of mononuclear inflammatory cells or foamy macrophages. In these areas, there may be edema or mucinous or myxoid changes of the stroma or even areas of necrosis. The presence of mucin lakes without viable tumor cells (acellular mucin) should be defined as a pathologically complete response. If it is difficult to differentiate between giant cells or fibroblast and tumor cells, it may be helpful to perform serial H\&E sections, mucin staining, or cytokeratin IHC in TRG grading.

\section{EGFR immunohistochemistry}

Expression of epidermal growth factor receptor (EGFR) by IHC has been reported in $25 \%$ to $90 \%$ of patients with CRC [60-64]. In almost all of the initial studies regarding the efficacy of targeted therapies with cetuximab or panitumumab in CRC patients, evidence of EGFR expression by IHC was essential for the application of therapeutic agents [65]. However, subsequent studies have shown no correlation between the degree of EGFR expression and the therapeutic responses to these drugs [66-68]. Thus, immunohistochemical expression of EGFR is not considered a predictor of response to EGFR-targeted drugs, and a number of recent studies do not include EGFR expression in selection criteria for anti-EGFR targeted therapy. However, in Korea, EGFR IHC has been routinely performed on CRC tissues of patients with stage IV CRC who are candidates for EGFR-targeted therapy according to the reimbursement criteria proposed by the Health Insurance Review and Evaluation Center, which mandates patient selection based on EGFR testing prior to application of EGFR-targeted therapy. In conclusion, whether immunohistochemical expression of EGFR accurately predicts the patients who would benefit from EGFR-targeted drugs has not 
been demonstrated until now.

\section{DNA mismatch repair immunohistochemistry}

IHC for the detection of DNA mismatch repair (MMR) proteins in CRC samples is a simple and useful tool to determine MMR deficiency, which is caused by germline mutation in one of the MMR genes (MLH1, MSH2, MSH6, or PMS2) or promoter $\mathrm{CPG}$ island hypermethylation of the MLH1 gene [69-71]. MMR deficiency results in a high level of microsatellite instability (MSI$\mathrm{H})$ that is characterized by genome-wide length alterations of DNA microsatellite repeat sequences [72]. Because MLH1 dimerizes with PMS2 in order to conduct DNA MMR function, when a mutation or promoter hypermethylation in $\mathrm{MLH1}$ occurs in CRC, IHC expression of both MLH1 and PMS2 is negative in the tumor $[69,70]$. Similarly, as MSH2 dimerizes with MSH6, MSH2-mutated CRCs show negativity for both MSH2 and MSH6 [69,70]. However, when mutations in PMS2 or MSH6 occur, expression of only PMS2 or MSH6, respectively, is lost, with the expression of MLH1 and MSH2 remaining intact [69,70].

Nuclear staining should be observed for the IHC detection of MMR positivity. MMR deficiency is determined when the nuclear expression of at least one of the MMR proteins is not observed in tumor cells (Fig. 6).

MMR IHC is a well-established histopathological screening tool for Lynch syndrome or sporadic MSI-H molecular subtype in CRCs [69-71]. Previous data and meta-analyses have shown that MMR deficiency (or MSI-H) in CRCs is significantly associated with both a better prognosis as well as resistance to 5 -fluorouracil-based adjuvant chemotherapy [72-74]. Moreover, recent evidence has indicated that MMR deficiency (or MSI-H) is a significant predictor of a positive response to immunotherapy using immune checkpoint blockade in solid tumors $[75,76]$. Therefore, the pathologic reporting of MMR or microsatellite instability (MSI) status is strongly recommended for all surgically resected CRC cases.

\section{Immunoscore}

Tumor-infiltrating lymphocytes (TILs) in tumor tissue has emerged as a strong prognostic factor in CRC. Many previous studies have consistently shown that TIL count is a strong prognostic factor with a high TIL count being significantly associated with a better prognosis in CRC [77]. Several investigations have reported that TIL count can be a strong predictor of patient prognosis in CRC regardless of both TNM staging and MSI [78,79]. The anti-tumor functions of TILs are conducted mainly by cytotoxic $\mathrm{T}$ cells. Thus, $\mathrm{IHC}$ for $\mathrm{CD} 3^{+}$and $\mathrm{CD} 8^{+} \mathrm{T}$ cells has been

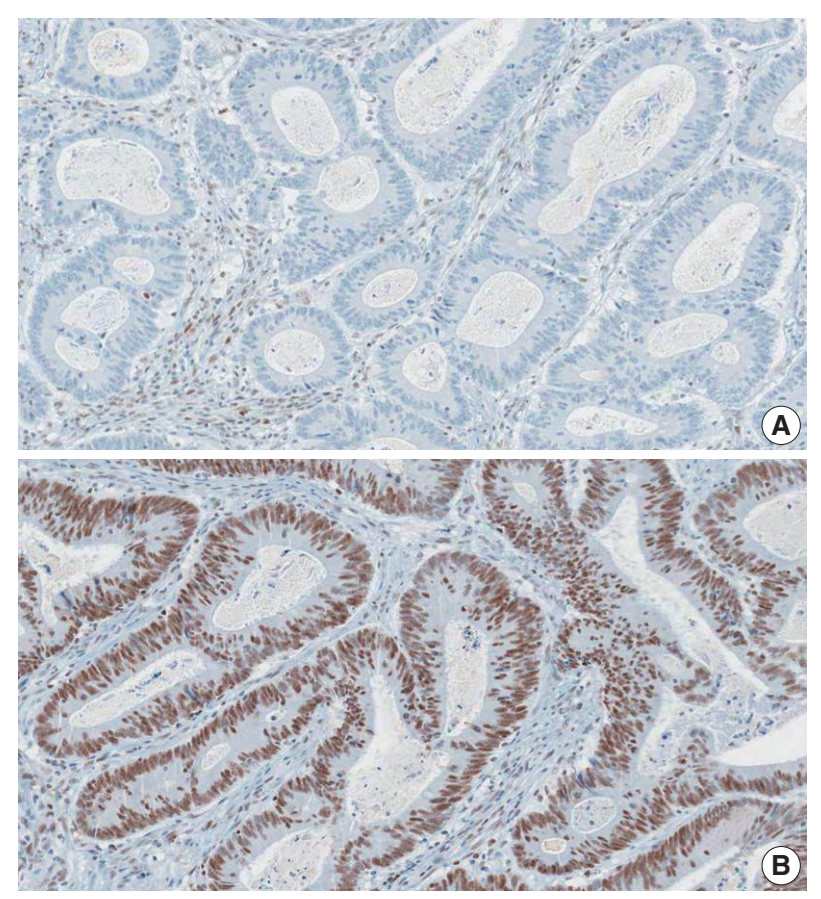

Fig. 6. A representative case of colorectal cancer with MMR deficiency (MLH1 deficiency). (A) MLH1 immunohistochemical staining showed negativity of nuclear expression in tumor cells. Note the retained nuclear expression in adjacent inflammatory cells. (B) $\mathrm{MSH} 2$ immunohistochemical staining demonstrated positivity of nuclear expression in tumor cells.

used as one of the major methods for the evaluation of TILs in CRC $[78,80]$.

Based on the accumulating data, a TIL-based methodology named "immunoscore" has been under development and validation since 2012 by an international consortium led by Dr. Jerome Galon (http://www.immunoscore.org) [80,81]. The steps for determining the immunoscore of a CRC are as follows: (1) selection of a representative tumor section, (2) IHC for $\mathrm{CD} 3$ and $\mathrm{CD} 8$ on the tumor section, (3) evaluation of $\mathrm{CD}^{+}$and $\mathrm{CD} 8^{+}$ cell densities at two tumor areas-invasive margin (IM) and tumor center (TC), (4) dichotomous categorization (high vs. low) of each of the four $\mathrm{CD} 3 / \mathrm{CD} 8$ variables $\left(\mathrm{CD} 3^{+} \mathrm{IM}, \mathrm{CD}^{+} \mathrm{TC}, \mathrm{CD} 8^{+}\right.$ $\mathrm{IM}$, and $\mathrm{CD} 8^{+} \mathrm{TC}$ ), (5) determination of the final immunoscore based on the four $\mathrm{CD} 3 / \mathrm{CD} 8$ variables (e.g., no "high" variable indicates I0; one "high" variable indicates I1; two "high" variables indicate I2; three "high" variables indicate I3; four "high" variables indicate I4).

Although there is strong evidence for the prognostic significance of the immunoscore in CRC, there is still a lack of global consensus regarding the application of immunoscore in terms of indication, evaluation, and classification. One of the critical limitations of the current immunoscoring system is the absence 
of a standard cut-off value for the high versus low categorization of $\mathrm{CD}^{+}$or $\mathrm{CD}^{+}$cell density. It is expected that a consensus established from digitalized image-based, automated analyses will aid the establishment of a standardized immunoscoring system.

\section{Microsatellite instability}

MSI is a condition of genome-wide alterations in the number of repeat nucleotide(s) caused by a defective mismatch repair (dMMR) system in the context of germline mutations in mismatch repair genes, including MLH1, MSH2, MSH6, and PMS2, or MLH1 promoter hypermethylation [72]. MSI testing is recommended for all CRC patients for the screening of Lynch syndrome in NCCN guidelines and guidelines from the American Society for Clinical Pathology (ASCP)/College of American Pathologists (CAP)/Association for Molecular Pathology (AMP)/ American Society of Clinical Oncology (ASCO) [82]. Moreover, MSI-H is associated with better prognosis but poor therapeutic response to 5 -fluorouracil-based cytotoxic chemotherapy $[83,84]$. Recently, MSI-H is considered as a predictive marker for PD-1 inhibitor-based cancer immunotherapy $[75,85]$.

The gold standard method to evaluate MSI is the capillary gel electrophoresis, which compares the length in polymerase chain reaction (PCR) products of mono- or di-nucleotide repeats between cancer tissue and normal tissue. The Bethesda panel is composed of two mononucleotide repeat markers (BAT-25 and BAT-26) and three dinucleotide repeat markers (D5S346, D2S123, and D17S250), while the quasimonomorphic mononucleotides panel is composed of five mononucleotide repeat markers (NR-21, NR-24, NR-27 [or Mono-27], BAT-25, and BAT-26) [86,87]. Real-time PCR can be an alternative method for MSI evaluation in quasimonomorphic mononucleotides panel. Cancers classified as MSI-H should undergo immunohistochemistry of mismatch repair genes to screen for Lynch syndrome. If the BRAF V600E mutation is detected in MSI-H CRCs with MLH1 loss, Lynch syndrome can be ruled out [88]. Because MSI corresponds to dMMR, immunohistochemistry of four mismatch repair proteins (MLH1, MSH2, MSH6, and PMS2) could be acceptable for an alternative method to capillary gel electrophoresis. The results of the MSI testing using the Bethesda panel are reported as MSI-H, MSI-low, and MSI-stable (MSS) if the tumor show instability in at least two, only one, and none of the 5 markers, respectively [87]. In determination of MSI using the quasimonomorphic mononucleotide panel, there is a controversy regarding the cut-off of MSI$\mathrm{H}(\geq 3 / 5$ or $\geq 2 / 5)[89,90]$.

\section{KRAS and NRAS mutation analysis}

The extended $R A S$ mutation test is a molecular test for the detection of mutations in exons 2 to 4 of KRAS and NRAS genes [82,91]. It is widely known that EGFR blockers improve survival in patients with metastatic CRCs. However, mutations of exons 2 to 4 of KRAS and NRAS genes are associated with resistance to EGFR blockers. Thus, European Society for Medical Oncology (ESMO) guidelines for metastatic CRCs, NCCN guidelines, and ASCP/CAP/AMP/ASCO guidelines recommend extended RAS mutation tests in patients with metastatic CRCs [82,91-93]. Besides, a point mutation of KRAS exon 2 is associated with poor prognosis in CRCs [94-98]. Sanger sequencing, pyrosequencing, and real-time PCR-based methods can be used for extended RAS mutation testing. Next generation sequencing (NGS) panels for solid tumors should include KRAS and NRAS tests in South Korea. The presence or absence of nucleotide and amino acid changes in KRAS and NRAS exons 2-4 should be reported with appropriate nomenclature.

\section{$B R A F$ mutation analysis}

BRAF V600E mutations are observed in approximately twothirds of MSI-H CRCs caused by MLH1 promoter hypermethylation, however, it never occurs in Lynch syndrome [99]. Thus, if the MSI-H CRCs harbor the BRAF V600E mutation, we can exclude Lynch syndrome. Genetic tests for germline mutation of mismatch repair genes are not indicated in MSI-high CRCs with the BRAF V600E mutation [88].

Of the molecular subtypes generated by MSI and BRAF/KRAS mutations, MSS CRCs with BRAF V600E mutations were associated with the worst prognosis. However, the association between BRAF V600E mutations and worse prognosis is weakened by the presence of MSI-H, because MSI-H CRCs with BRAF V600E mutations showed no difference in survival compared with MSS CRCs with wild-type KRAS/BRAF [95-98]. Hence, MSI tests and BRAF mutation tests should be performed in CRC patients. Two retrospective studies showed that the BRAF V600E mutation is associated with shorter relapse-free survival and overall survival in metastatic CRC patients that underwent liver resection $[98,100]$.

Some studies reported that the BRAF V600E mutation is associated with poor therapeutic response to EGFR blockers. However, it is still controversial whether the BRAF V600E mutation is an independent predictive marker for EGFR blockers [101,102]. 2017 National Comprehensive Cancer Network (NCCN) guidelines recommend BRAF V600E mutation testing for metastatic CRC patients; however, ASCP/CAP/AMP/ 
ASCO and ESMO guidelines for metastatic CRCs do not recommend BRAF V600E mutation testing for metastatic CRC [82,91].

Sanger sequencing, pyrosequencing, and real-time PCR-based methods can be used for BRAF mutation testing. NGS panels for solid tumors should include BRAF tests in South Korea. The presence or absence of nucleotide and amino acid changes in BRAF exon 15 should be reported. Appropriate nomenclature should be used.

\section{Supplementary Materials}

The Data Supplement is available with this article at https:// doi.org/10.4132/jptm.2019.09.28.

\section{ORCID}

Baek-hui Kim: https://orcid.org/0000-0001-6793-1991

Joon Mee Kim: https://orcid.org/0000-0003-1355-4187

Gyeong Hoon Kang: https://orcid.org/0000-0003-2380-6675

Hee Jin Chang: https://orcid.org/0000-0003-2263-2247

Dong Wook Kang: https://orcid.org/0000-0002-4300-3469

Jung Ho Kim: https://orcid.org/0000-0002-6031-3629

Jeong Mo Bae: https://orcid.org/0000-0003-0462-3072

An Na Seo: https://orcid.org/0000-0001-6412-3067

Ho Sung Park: https://orcid.org/0000-0002-4879-874X

Yun Kyung Kang: https://orcid.org/0000-0002-2075-4665

Kyung-Hwa Lee: https://orcid.org/0000-0002-3935-0361

Mee Yon Cho: https://orcid.org/0000-0002-7955-4211

In-Gu Do: https://orcid.org/0000-0001-7832-7116

Hye Seung Lee: https://orcid.org/0000-0002-1667-7986

Hee Kyung Chang: https://orcid.org/0000-0002-4843-5316

Do Youn Park: https://orcid.org/0000-0001-7641-1509

Hyo Jeong Kang: https://orcid.org/0000-0002-5285-8282

Jin Hee Sohn: https://orcid.org/0000-0002-4735-3853

Mee Soo Chang: https://orcid.org/0000-0002-0948-799X

Eun Sun Jung: https://orcid.org/0000-0002-8451-939X

So-Young Jin: https://orcid.org/0000-0002-9900-8322

Eunsil Yu: https://orcid.org/0000-0001-5474-9744

Hye Seung Han: https://orcid.org/0000-0002-3591-9995

Youn Wha Kim: https://orcid.org/0000-0002-8259-5620

\section{Author Contributions}

Conceptualization: BHK, JMK, GHK, HJC, DWK, JHK, JMB, ANS, HSP, YKK, KHL, MYC, IGD, HSL, HKC, JHS, MSC, ESJ, SYJ, EY, HSH.

Project administration: BHK, JMK, GHK, HJC, DYP.
Supervision: JMK, GHK, HJC, SYJ, ESJ, YWK, MSC, JHS, EY.

Writing—original draft preparation: HSP, ANS, JHK, IGD, YKK, MYC, JMK, DWK, JMB, BHK, HSL, KHL.

Writing—review \& editing: BHK, JMK, GHK, HJC, DWK, JHK, JMB, ANS, HSP, YKK, KHL, MYC, IGD, HSL, HKC, DYP, HJK, JHS, MSC, ESJ, SYJ, EY, HSH, YWK.

\section{Conflicts of Interest}

G.H.K., J.H.K., and H.S.L., contributing editors of the Journal of Pathology and Translational Medicine, were not involved in the editorial evaluation or decision to publish this article. All remaining authors have declared no conflicts of interest.

\section{Funding}

No funding to declare.

\section{REFERENCES}

1. Chang HJ, Park CK, Kim WH, et al. A standardized pathology report for colorectal cancer. Korean J Pathol 2006; 40: 193-203.

2. Ministry of Health and Welfare. Annual report of cancer statistics in Korea in 2015. Sejong: Ministry of Health and Welfare, 2017.

3. Kakar S, Shi C, Berho ME, et al. Protocol for the examination of specimens from patients with primary carcinoma of the colon and rectum, version 4.0.0.0. Illinois: College of American Pathologists, 2017.

4. Amin MB, Edge S, Greene F, et al. AJCC cancer staging system. 8th ed. New York: Springer, 2017.

5. WHO Classification of Tumours Editorial Board. WHO classification of tumours: digestive system tumours. 5th ed. Geneva: World Health Organization, 2019.

6. Fritz AG, Percy C, Jack A, et al. International classification of diseases for oncology (ICD-O). 3rd ed. 1st rev. Lyon: International Agency for Research on Cancer, 2013.

7. Langman G, Loughrey M, Shepherd N, Quirke P. Association of Coloproctology of Great Britain \& Ireland (ACPGBI): guidelines for the management of cancer of the colon, rectum and anus (2017)pathology standards and datasets. Colorectal Dis 2017; 19 Suppl 1: 74-81.

8. Nagtegaal I, Gaspar C, Marijnen C, Van De Velde C, Fodde R, Van Krieken $\mathrm{H}$. Morphological changes in tumour type after radiotherapy are accompanied by changes in gene expression profile but not in clinical behaviour. J Pathol 2004; 204: 183-92.

9. Verdu M, Roman R, Calvo M, et al. Clinicopathological and molecular characterization of colorectal micropapillary carcinoma. Mod 
Pathol 2011; 24: 729-38.

10. Lee HJ, Eom DW, Kang GH, et al. Colorectal micropapillary carcinomas are associated with poor prognosis and enriched in markers of stem cells. Mod Pathol 2013; 26: 1123-31.

11. Nassar H. Carcinomas with micropapillary morphology: clinical significance and current concepts. Adv Anat Pathol 2004; 11: 297303.

12. Xu F, Xu J, Lou Z, et al. Micropapillary component in colorectal carcinoma is associated with lymph node metastasis in T1 and T2 Stages and decreased survival time in TNM stages I and II. Am J Surg Pathol 2009; 33: 1287-92.

13. Haupt B, Ro JY, Schwartz MR, Shen SS. Colorectal adenocarcinoma with micropapillary pattern and its association with lymph node metastasis. Mod Pathol 2007; 20: 729-33.

14. Jakubowska K, Guzinska-Ustymowicz K, Pryczynicz A. Invasive micropapillary component and its clinico-histopathological significance in patients with colorectal cancer. Oncol Lett 2016; 12: 1154-8.

15. Tuppurainen K, Makinen JM, Junttila O, et al. Morphology and microsatellite instability in sporadic serrated and non-serrated colorectal cancer. J Pathol 2005; 207: 285-94.

16. Patai AV, Molnár B, Tulassay Z, Sipos F. Serrated pathway: alternative route to colorectal cancer. World J Gastroenterol 2013; 19: 607-15.

17. Mäkinen MJ. Colorectal serrated adenocarcinoma. Histopathology 2007; 50: 131-50.

18. Barresi V, Reggiani Bonetti L, Ieni A, Domati F, Tuccari G. Prognostic significance of grading based on the counting of poorly differentiated clusters in colorectal mucinous adenocarcinoma. Hum Pathol 2015; 46: 1722-9.

19. Bosman FT, Carneiro F, Hruban RH, Theise ND. WHO classification of tumours of the digestive system. 4th ed. Lyon: International Agency for Research on Cancer, 2010.

20. Kojima M, Shimazaki H, Iwaya K, et al. Intramucosal colorectal carcinoma with invasion of the lamina propria: a study by the Japanese Society for Cancer of the Colon and Rectum. Hum Pathol 2017; 66: 230-7.

21. Panarelli NC, Schreiner AM, Brandt SM, Shepherd NA, Yantiss RK. Histologic features and cytologic techniques that aid pathologic stage assessment of colonic adenocarcinoma. Am J Surg Pathol 2013; $37: 1252-8$

22. Uehara K, Nakanishi Y, Shimoda T, Taniguchi H, Akasu T, Moriya Y. Clinicopathological significance of microscopic abscess formation at the invasive margin of advanced low rectal cancer. Br J Surg 2007; 94: 239-43.

23. Smith KD, Tan D, Das P, et al. Clinical significance of acellular mucin in rectal adenocarcinoma patients with a pathologic com- plete response to preoperative chemoradiation. Ann Surg 2010; 251: 261-4.

24. Kang CM, Lim SB, Hong SM, et al. Prevalence and clinical significance of cellular and acellular mucin in patients with locally advanced mucinous rectal cancer who underwent preoperative chemoradiotherapy followed by radical surgery. Colorectal Dis 2016; 18: O10-6.

25. Kitajima K, Fujimori T, Fujii S, et al. Correlations between lymph node metastasis and depth of submucosal invasion in submucosal invasive colorectal carcinoma: a Japanese collaborative study. J Gastroenterol 2004; 39: 534-43.

26. Bosch SL, Teerenstra S, de Wilt JH, Cunningham C, Nagtegaal ID. Predicting lymph node metastasis in pT1 colorectal cancer: a systematic review of risk factors providing rationale for therapy decisions. Endoscopy 2013; 45: 827-34.

27. Haggitt RC, Glotzbach RE, Soffer EE, Wruble LD. Prognostic factors in colorectal carcinomas arising in adenomas: implications for lesions removed by endoscopic polypectomy. Gastroenterology 1985; 89: 328-36.

28. Kikuchi R, Takano M, Takagi K, et al. Management of early invasive colorectal cancer: risk of recurrence and clinical guidelines. Dis Colon Rectum 1995; 38: 1286-95.

29. Watanabe T, Muro K, Ajioka Y, et al. Japanese Society for Cancer of the Colon and Rectum (JSCCR) guidelines 2016 for the treatment of colorectal cancer. Int J Clin Oncol 2018; 23: 1-34.

30. Betge J, Pollheimer MJ, Lindtner RA, et al. Intramural and extramural vascular invasion in colorectal cancer: prognostic significance and quality of pathology reporting. Cancer 2012; 118: 628-38.

31. Kim WH, Park CK, Kim YB, et al. A standardized pathology report for gastric cancer. Korean J Pathol 2005; 39: 106-13.

32. Liebig C, Ayala G, Wilks J, et al. Perineural invasion is an independent predictor of outcome in colorectal cancer. J Clin Oncol 2009; 27: 5131-7.

33. Liebig C, Ayala G, Wilks JA, Berger DH, Albo D. Perineural invasion in cancer: a review of the literature. Cancer 2009; 115: 3379-91.

34. Gibson JA, Odze RD. Pathology of premalignant colorectal neoplasia. Dig Endosc 2016; 28: 312-23.

35. Rex DK, Ahnen DJ, Baron JA, et al. Serrated lesions of the colorectum: review and recommendations from an expert panel. Am J Gastroenterol 2012; 107: 1315-29.

36. Bateman AC, Shepherd NA. UK guidance for the pathological reporting of serrated lesions of the colorectum. J Clin Pathol 2015; 68: 585-91.

37. Liu C, Walker NI, Leggett BA, Whitehall VL, Bettington ML, Rosty C. Sessile serrated adenomas with dysplasia: morphological patterns and correlations with MLH1 immunohistochemistry. Mod 
Pathol 2017; 30: 1728-38.

38. Chetty R, Hafezi-Bakhtiari S, Serra S, Colling R, Wang LM. Traditional serrated adenomas (TSAs) admixed with other serrated (socalled precursor) polyps and conventional adenomas: a frequent occurrence. J Clin Pathol 2015; 68: 270-3.

39. Anwar MA, D'Souza F, Coulter R, Memon B, Khan IM, Memon MA. Outcome of acutely perforated colorectal cancers: experience of a single district general hospital. Surg Oncol 2006; 15: 91-6.

40. Mitrovic B, Schaeffer DF, Riddell RH, Kirsch R. Tumor budding in colorectal carcinoma: time to take notice. Mod Pathol 2012; 25: 1315-25.

41. Choi DH, Sohn DK, Chang HJ, Lim SB, Choi HS, Jeong SY. Indications for subsequent surgery after endoscopic resection of submucosally invasive colorectal carcinomas: a prospective cohort study. Dis Colon Rectum 2009; 52: 438-45.

42. Ueno H, Mochizuki H, Hashiguchi $Y$, et al. Risk factors for an adverse outcome in early invasive colorectal carcinoma. Gastroenterology 2004; 127: 385-94.

43. Wang LM, Kevans D, Mulcahy H, et al. Tumor budding is a strong and reproducible prognostic marker in T3N0 colorectal cancer. Am J Surg Pathol 2009; 33: 134-41.

44. Giger OT, Comtesse SC, Lugli A, Zlobec I, Kurrer MO. Intra-tumoral budding in preoperative biopsy specimens predicts lymph node and distant metastasis in patients with colorectal cancer. Mod Pathol 2012; 25: 1048-53.

45. Rogers AC, Gibbons D, Hanly AM, et al. Prognostic significance of tumor budding in rectal cancer biopsies before neoadjuvant therapy. Mod Pathol 2014; 27: 156-62.

46. Lugli A, Kirsch R, Ajioka Y, et al. Recommendations for reporting tumor budding in colorectal cancer based on the International Tumor Budding Consensus Conference (ITBCC) 2016. Mod Pathol 2017; 30: 1299-311.

47. Koelzer VH, Zlobec I, Berger MD, et al. Tumor budding in colorectal cancer revisited: results of a multicenter interobserver study. Virchows Arch 2015; 466: 485-93.

48. Koelzer VH, Assarzadegan N, Dawson H, et al. Cytokeratinbased assessment of tumour budding in colorectal cancer: analysis in stage II patients and prospective diagnostic experience. J Pathol Clin Res 2017; 3: 171-8.

49. Jass JR, Love SB, Northover JM. A new prognostic classification of rectal cancer. Lancet 1987; 1: 1303-6.

50. Bosch SL, Nagtegaal ID. The importance of the pathologist's role in assessment of the quality of the mesorectum. Curr Colorectal Cancer Rep 2012; 8: 90-8.

51. Aklilu M, Eng C. The current landscape of locally advanced rectal cancer. Nat Rev Clin Oncol 2011; 8: 649-59.
52. Bibeau F, Rullier A, Jourdan MF, et al. Locally advanced rectal cancer management: which role for the pathologist in 2011? Ann Pathol 2011; 31: 433-41.

53. Dhadda AS, Dickinson P, Zaitoun AM, Gandhi N, Bessell EM. Prognostic importance of Mandard tumour regression grade following pre-operative chemo/radiotherapy for locally advanced rectal cancer. Eur J Cancer 2011; 47: 1138-45.

54. Mihaylova I, Parvanova V, Velikova C, Kurteva G, Ivanova D. Degree of tumor regression after preoperative chemo-radiotherapy in locally advanced rectal cancer-Preliminary results. Rep Pract Oncol Radiother 2011; 16: 237-42.

55. Vallböhmer D, Bollschweiler E, Brabender J, et al. Evaluation of histological regression grading systems in the neoadjuvant therapy of rectal cancer: do they have prognostic impact? Int J Colorectal Dis 2012; 27: 1295-301.

56. Kim SH, Chang HJ, Kim DY, et al. What is the ideal tumor regression grading system in rectal cancer patients after preoperative chemoradiotherapy? Cancer Res Treat 2016; 48: 998-1009.

57. Mandard AM, Dalibard F, Mandard JC, et al. Pathologic assessment of tumor regression after preoperative chemoradiotherapy of esophageal carcinoma: clinicopathologic correlations. Cancer 1994; 73: 2680-6.

58. Dworak O, Keilholz L, Hoffmann A. Pathological features of rectal cancer after preoperative radiochemotherapy. Int J Colorectal Dis 1997; 12: 19-23.

59. Ryan R, Gibbons D, Hyland JM, et al. Pathological response following long-course neoadjuvant chemoradiotherapy for locally advanced rectal cancer. Histopathology 2005; 47: 141-6.

60. Krasinskas AM. EGFR Signaling in Colorectal Carcinoma. Patholog Res Int 2011; 2011: 932932.

61. Goldstein NS, Armin M. Epidermal growth factor receptor immunohistochemical reactivity in patients with American Joint Committee on Cancer Stage IV colon adenocarcinoma: implications for a standardized scoring system. Cancer 2001; 92: 1331-46.

62. McKay JA, Murray LJ, Curran S, et al. Evaluation of the epidermal growth factor receptor (EGFR) in colorectal tumours and lymph node metastases. Eur J Cancer 2002; 38: 2258-64.

63. Spano JP, Fagard R, Soria JC, Rixe O, Khayat D, Milano G. Epidermal growth factor receptor signaling in colorectal cancer: preclinical data and therapeutic perspectives. Ann Oncol 2005; 16: 189-94.

64. Resnick MB, Routhier J, Konkin T, Sabo E, Pricolo VE. Epidermal growth factor receptor, c-MET, beta-catenin, and p53 expression as prognostic indicators in stage II colon cancer: a tissue microarray study. Clin Cancer Res 2004; 10: 3069-75.

65. de Castro-Carpeno J, Belda-Iniesta C, Casado Saenz E, Hernandez Agudo E, Feliu Batlle J, Gonzalez Baron M. EGFR and colon cancer: 
a clinical view. Clin Transl Oncol 2008; 10: 6-13.

66. Saltz LB, Meropol NJ, Loehrer PJ Sr, Needle MN, Kopit J, Mayer RJ. Phase II trial of cetuximab in patients with refractory colorectal cancer that expresses the epidermal growth factor receptor. J Clin Oncol 2004; 22: 1201-8.

67. Vallböhmer D, Zhang W, Gordon M, et al. Molecular determinants of cetuximab efficacy. J Clin Oncol 2005; 23: 3536-44.

68. Ogino S, Meyerhardt JA, Cantor M, et al. Molecular alterations in tumors and response to combination chemotherapy with gefitinib for advanced colorectal cancer. Clin Cancer Res 2005; 11: 6650-6.

69. Geiersbach KB, Samowitz WS. Microsatellite instability and colorectal cancer. Arch Pathol Lab Med 2011; 135: 1269-77.

70. Pino MS, Chung DC. Microsatellite instability in the management of colorectal cancer. Expert Rev Gastroenterol Hepatol 2011; 5: 385-99.

71. Samowitz WS. Evaluation of colorectal cancers for Lynch syndrome: practical molecular diagnostics for surgical pathologists. Mod Pathol 2015; 28 Suppl 1: S109-13.

72. Boland CR, Goel A. Microsatellite instability in colorectal cancer. Gastroenterology 2010; 138: 2073-87.

73. Guastadisegni C, Colafranceschi M, Ottini L, Dogliotti E. Microsatellite instability as a marker of prognosis and response to therapy: a meta-analysis of colorectal cancer survival data. Eur J Cancer 2010; 46: 2788-98.

74. Pritchard CC, Grady WM. Colorectal cancer molecular biology moves into clinical practice. Gut 2011; 60: 116-29.

75. Le DT, Uram JN, Wang H, et al. PD-1 blockade in tumors with mismatch-repair deficiency. N Engl J Med 2015; 372: 2509-20.

76. Le DT, Durham JN, Smith KN, et al. Mismatch repair deficiency predicts response of solid tumors to PD-1 blockade. Science 2017; 357: 409-13.

77. Roxburgh CS, McMillan DC. The role of the in situ local inflammatory response in predicting recurrence and survival in patients with primary operable colorectal cancer. Cancer Treat Rev 2012; 38: 451-66

78. Kirilovsky A, Marliot F, El Sissy C, Haicheur N, Galon J, Pages F. Rational bases for the use of the Immunoscore in routine clinical settings as a prognostic and predictive biomarker in cancer patients. Int Immunol 2016; 28: 373-82.

79. Mlecnik B, Bindea G, Angell HK, et al. Integrative analyses of colorectal cancer show immunoscore is a stronger predictor of patient survival than microsatellite instability. Immunity 2016; 44: 698-711.

80. Galon J, Mlecnik B, Bindea G, et al. Towards the introduction of the 'Immunoscore' in the classification of malignant tumours. J Pathol 2014; 232: 199-209.
81. Galon J, Pagès F, Marincola FM, et al. Cancer classification using the Immunoscore: a worldwide task force. J Transl Med 2012; 10: 205.

82. Sepulveda AR, Hamilton SR, Allegra CJ, et al. Molecular biomarkers for the evaluation of colorectal cancer: guideline from the American Society for Clinical Pathology, College of American Pathologists, Association for Molecular Pathology, and the American Society of Clinical Oncology. J Clin Oncol 2017; 35: 1453-86.

83. Zaanan A, Shi Q, Taieb J, et al. Role of deficient DNA mismatch repair status in patients with stage III colon cancer treated with FOLFOX adjuvant chemotherapy: a pooled analysis from 2 randomized clinical trials. JAMA Oncol 2018; 4: 379-83.

84. Sargent DJ, Marsoni S, Monges G, et al. Defective mismatch repair as a predictive marker for lack of efficacy of fluorouracil-based adjuvant therapy in colon cancer. J Clin Oncol 2010; 28: 3219-26.

85. Overman MJ, McDermott R, Leach JL, et al. Nivolumab in patients with metastatic DNA mismatch repair-deficient or microsatellite instability-high colorectal cancer (CheckMate 142): an open-label, multicentre, phase 2 study. Lancet Oncol 2017; 18: 1182-91.

86. Umar A, Boland CR, Terdiman JP, et al. Revised Bethesda Guidelines for hereditary nonpolyposis colorectal cancer (Lynch syndrome) and microsatellite instability. J Natl Cancer Inst 2004; 96: 261-8.

87. Boland CR, Thibodeau SN, Hamilton SR, et al. A National Cancer Institute Workshop on Microsatellite Instability for cancer detection and familial predisposition: development of international criteria for the determination of microsatellite instability in colorectal cancer. Cancer Res 1998; 58: 5248-57.

88. Adar T, Rodgers LH, Shannon KM, et al. A tailored approach to BRAF and MLH1 methylation testing in a universal screening program for Lynch syndrome. Mod Pathol 2017; 30: 440-7.

89. Buhard O, Cattaneo F, Wong YF, et al. Multipopulation analysis of polymorphisms in five mononucleotide repeats used to determine the microsatellite instability status of human tumors. J Clin Oncol 2006; 24: 241-51.

90. Goel A, Nagasaka T, Hamelin R, Boland CR. An optimized pentaplex PCR for detecting DNA mismatch repair-deficient colorectal cancers. PLoS One 2010; 5: e9393.

91. Van Cutsem E, Cervantes A, Adam R, et al. ESMO consensus guidelines for the management of patients with metastatic colorectal cancer. Ann Oncol 2016; 27: 1386-422.

92. Amado RG, Wolf M, Peeters M, et al. Wild-type KRAS is required for panitumumab efficacy in patients with metastatic colorectal cancer. J Clin Oncol 2008; 26: 1626-34.

93. Douillard JY, Oliner KS, Siena S, et al. Panitumumab-FOLFOX4 treatment and RAS mutations in colorectal cancer. $\mathrm{N}$ Engl J Med 
2013; 369: 1023-34.

94. Rui Y, Wang C, Zhou Z, Zhong X, Yu Y. K-Ras mutation and prognosis of colorectal cancer: a meta-analysis. Hepatogastroenterology 2015; 62: 19-24.

95. Phipps AI, Limburg PJ, Baron JA, et al. Association between molecular subtypes of colorectal cancer and patient survival. Gastroenterology 2015; 148: 77-87.

96. Sinicrope FA, Shi Q, Smyrk TC, et al. Molecular markers identify subtypes of stage III colon cancer associated with patient outcomes. Gastroenterology 2015; 148: 88-99.

97. Taieb J, Le Malicot K, Shi Q, et al. Prognostic value of BRAF and KRAS mutations in MSI and MSS stage III colon cancer. J Natl Cancer Inst 2017; 109: djw272.

98. Schirripa $\mathrm{M}$, Bergamo $\mathrm{F}$, Cremolini $\mathrm{C}$, et al. $B R A F$ and $R A S$ mutations as prognostic factors in metastatic colorectal cancer patients undergoing liver resection. Br J Cancer 2015; 112: 1921-8.

99. Wang L, Cunningham JM, Winters JL, et al. BRAF mutations in colon cancer are not likely attributable to defective DNA mismatch repair. Cancer Res 2003; 63: 5209-12.

100. Loes IM, Immervoll $\mathrm{H}$, Sorbye $\mathrm{H}$, et al. Impact of KRAS, BRAF, PIK3CA, TP53 status and intraindividual mutation heterogeneity on outcome after liver resection for colorectal cancer metastases. Int J Cancer 2016; 139: 647-56.

101. Di Nicolantonio F, Martini M, Molinari F, et al. Wild-type BRAF is required for response to panitumumab or cetuximab in metastatic colorectal cancer. J Clin Oncol 2008; 26: 5705-12.

102. Pietrantonio F, Petrelli F, Coinu A, et al. Predictive role of BRAF mutations in patients with advanced colorectal cancer receiving cetuximab and panitumumab: a meta-analysis. Eur J Cancer 2015; 51: 587-94. 


\section{SUPPLEMENTARY MATERIAL 1}

\section{대장암 병리보고서 기재사항 표준화 2판}

대장암 병리보고서 기재사항 표준화는 대장암의 병리 보고서를 표준화 하기 위해 소화기병리학연구회에서 개발하였으며 대한병리학회지에 2006년 발표되었다[1]. 당시 국내에서 네 번째로 자주 발생하는 암이었던 대장암은 현재 국내에서 두 번 째로 자주 발생하는 암이 될 정도로 발생률이 높아졌으며, 병리학적인 진단 기준이나 항목도 많은 변화가 있었다[1,2]. 또한, 표적치료제와 면역치료제가 대장암에 도입이 되면서 대장암과 관련된 분자병리 검사 또한 대장암의 치료에 필요한 항목이 됨에 따라, 기존의 기재사항 표준화 보고서로는 변화하는 대장암 병리 진단을 모두 반영하기 어렵게 되었다.

대한병리학회 소화기병리학 연구회에서는 많은 병리의사들이 사용하고 있는 대장암 병리보고서 기재사항 표준화의 개정 에 대한 요구가 많다고 판단하였고, 2017년 9월부터 2018년 10월까지 개정작업을 위한 소위원회를 구성하여 수차례의 논의 를 거친 후 <대장암 병리보고서 기재사항 표준화 2판>을 완성하였다. 기존의 표준화 지침을 기반으로, 미국병리학회 프로토 콜, American Joint Committee on Cancer (AJCC) 8판, World Health Organization (WHO) 분류 5판, 종양학 국제 질병 분류(International Classification of Diseases for Oncology) 등을 참고하였다[3-6].

표준화된 대장암 병리 보고서의 목적은 대장암 환자들의 표준화된 진단과 진료가 가능하게 하는 것이고, 국내 다기관 임 상시험이나 국제 연구에서도 동일한 환자군을 선택하고 정보를 교환하는 데 도움을 줄 수 있도록 하는 것이다. 현재까지의 최신지견을 모두 수록하면 좋겠지만 이럴 경우 병리의사의 업무량 증가를 가져오게 되고, 현행 의료체계에서는 병리진단의 세부적인 업무량 증가가 의료수가에 충분히 반영되기 어려워 비실용적인 표준화 보고서가 될 수 있다고 보았다. 따라서, 이 전 보고서와 같이 대장암의 병리 진단에서 암의 기본적인 병리학적 소견과 예후 판정에 필요한 부분들은 표준 기재사항으로 분류하였고, 그 외에 예후 관련 인자들이나 보조 치료에 필요한 사항들은 선택 기재사항으로 분류하여, 각 기관에서는 기관 의 특성에 맞추어서 내용들을 선택하여 사용할 수 있도록 하였다. 초판과 마찬가지로 병리보고서의 국제화를 위하여 영어로 기재하도록 하였으며, 앞으로 각 항목의 판독 기준이나 분류법이 바뀌더라도 추후에 추적할 수 있도록 약자나 숫자로 된 분 류법의 사용을 제한하였다.

대한병리학회지가 Journal of Patbology and Translational Medicine의 영문 논문으로 바뀌게 되면서 게재하는 보고서는 영문으 로 작성하게 되었으나, 병리의사들이 쉽게 이해하고 사용할 수 있도록 하기 위해서 한글판을 따로 작성하였다.

\section{절제 대장의 표준 기재사항}

종양이 두 개 이상 있는 경우에는 가장 침윤이 깊은 종양부터 각각의 종양에 대한 항목들을 적되, 국소림프절전이(regional lymph node metastasis), 연관소견(associated findings), 독립병변(separate lesions) 항목은 가장 깊은 종양에만 적는다.

\footnotetext{
Specimen type

Right hemicolectomy

Transverse hemicolectomy

Left hemicolectomy

Anterior resection

Low anterior resection

Abdominoperineal resection

Subtotal/total colectomy

Total proctocolectomy

Transanal excision

Endoscopic mucosal resection

$\square$ Other: (specify:
} 
해설: 본 기재사항은 수술로 절제한 대장/직장암뿐만 아니라 내시경 절제 혹은 경항문절제 표본에서도 동일하게 적용할 수 있도록 하였다.

\author{
Histopathologic type of invasive carcinoma \\ Adenocarcinoma, NOS \\ $\square$ low-grade (well differentiated and moderately differentiated) \\ $\square$ high-grade (poorly differentiated) \\ $\square$ Mucinous adenocarcinoma \\ Signet ring cell carcinoma \\ Medullary carcinoma \\ $\square$ Serrated adenocarcinoma \\ Micropapillary adenocarcinoma \\ $\square$ Squamous cell (epidermoid) carcinoma (excluding upwardly spreading anal tumors) \\ $\square$ Adenosquamous carcinoma \\ $\square$ Small cell neuroendocrine carcinoma \\ Large cell neuroendocrine carcinoma \\ Mixed neuroendocrine-non-neuroendocrine neoplasm \\ Undifferentiated carcinoma \\ $\square$ Other: (specify: \\ )
}

해설: 종양의 조직학적 유형은 $\mathrm{WHO}$ 분류 5판을 기본적으로 따른다[5]. 비록 거의 대부분의 대장 및 직장암은 샘암종(adenocarcinoma, not otherwise specified [NOS])이지만, 다른 조직학적 이형이 섞여 있는 경우에 대해 따로 언급하는 것을 권장한 다; 이는 어떤 조직학적 이형은 특이한 분자유전학적 특징과 환자의 예후와 관련 있을 수 있기 때문이다[5,7]. WHO 분류와 AJCC 8판에 기술된 대장 및 직장암의 대표적인 조직학적 유형은 위의 표와 같다[4,5].

점액 샘암종(mucinous adenocarcinoma)과 인환세포암종(signet ring cell carcinoma)의 경우 세포 외 점액과 인환세포가 각각 종양의 $50 \%$ 를 초과할 때 진단할 수 있다. 만약 $50 \%$ 이하인 경우 주조직학적 유형과 함께 점액과 인환세포의 비율을 기술해 주는 것을 권장한다[5]. 주의할 점은, 수술전 전보조치료를 받은 경우 점액을 생성할 수 있으므로, 이런 경우 수술 전 병리검 체의 진단을 기술하는 것을 권장한다[8]. 수질암종(medullary carcinoma)은 드문 조직학적 유형으로 미분화암종(undifferentiated carcinoma)과의 감별을 요하고, 암세포내 림프구나 호중구 침윤이 현저하며 그 사이사이 암세포가 고형성 또는 판(sheet)형 태로 보이는 경우 진단한다[5,7]. 수질암종의 종양 세포들은 보통 호산성의 풍부한 세포질과 수포성 핵, 저명한 핵소체를 보 여준다[5]. 다른 드문 조직학적 유형인 미세유두 샘암종(micropapillary adenocarcinoma)은 작은 종양세포 군집 주위로 간질의 빈 공간이 존재하여 림프관 또는 미세혈관을 침윤한 것처럼 보이는 경우 진단할 수 있다[9-11]. 미세유두 선암종의 경우 림 프절 전이의 위험도가 높은 것으로 알려져 있으며 림프관 침윤이나 혈관 침윤과 같은 나쁜 예후를 보이는 인자들이 흔히 관 찰된다[9-13]. 하지만, 미세유두의 특징만 있는 대장 및 직장암은 아주 극히 드물며, 하나의 다른 조직유형에서 미세유두의 이형이 공존하는 경우가 대부분이다[5,14]. WHO 분류에서는 미세유두 아형이 전체 종양의 $5 \%$ 이상일 경우 미세유두 선암 종으로 진단하도록 되어 있으나, 아직까지 미세유두 샘암종의 진단을 위한 표준화된 미세유두 이형의 비율은 논란의 여지가 있어서, 본 소위원회에서는 의견 일치에 도달하지 못 하였다[5]. 톱니형 샘암종(serrated adenocarcinoma)은 현저한 상피의 톱 니 모양을 가진 톱니모양병변과 유사한 형태를 가지는 샘암종으로, 낮은 핵-세포질 비율을 가지며 붉은 풍부한 세포질과 수 포성 핵을 보이는 특징을 가지고 있다[5,15,16]. 일부 연구에서 톱니형 샘암종의 진단 기준을 제시하고 있으나[17], 아직까지 톱니형 샘암종의 진단 기준에 대한 일치된 기준은 제시되지 않았다. 샘편평세포암종(adenosquamous carcinoma)은 분명한 편 
평상피 암종부분이 확실히 보여야 진단할 수 있다. WHO 분류에서는 식도와 위의 종양에서는 샘암종과 편평세포암종 분화 를 보이는 부분이 각각 $20 \%$ 와 $25 \%$ 이상일 경우 샘편평세포암종을 진단하도록 하고 있다[5]. 그러나 대장에서는 이 비율이 제시되지 않아 본 위원회에서는 이전 보고서의 내용과 같이 편평세포암종 부분이 "more than occasional small foci" 일 때 샘편 평세포암종을 진단하도록 권고한다[1]. 미분화암종은 형태학적 소견과 면역염색, 분자병리 소견을 종합하여도 상피성 분화 외에는 특정 분화를 보이지 않을 경우 진단한다[5]. 샘종양 샘암종(adenoma-like adenocarcinoma)은 융모샘암종(villous adenocarcinoma)라고도 불리우며, WHO 5판에 대장암의 조직학적 아형으로 처음 도입되었다[5]. 샘종양 샘암종은 종양의 침윤성 부위의 $50 \%$ 이상이 융모형 샘종같은 좋은 분화를 보이는 암종으로, 팽창성 경계(pushing border)를 가지고 섬유조직형성(desmoplasia)이 거의 관찰되지 않는다[5]. 샘종양 샘암종을 대장암의 특정 아형으로 분류해야 하는지는 아직 논란이 있기 때문 에 본 보고서에서 아형으로 추가하지 않았다.

종양의 분화도는 샘 구조를 만드는 면적으로 결정하며, 이러한 종양의 분화도는 샘암종(adenocarcinoma, NOS)의 조직학적 유형을 보이는 경우에 적용한다[7]. 이는 다른 조직학적 유형은 그들 고유의 예후의 특징을 가지고 있기 때문이다[7]. 최근 점 액 샘암종 또한 분화도가 예후 결정에 중요하다는 것이 밝혀지고 있으나, 분화도를 결정하기 위한 표준화된 기준은 제시되지 않고 있다[5,18]. 종양의 분화도는 저등급(low-grade)와 고등급(high-grade)의 두 단계로 나누는 것을 권장한다[5]. 기존의 분화 도를 나누는 기준은 선구조를 만드는 면적이 95\%를 초과하면 고분화형 샘암종, 50\%-95\%면 중분화형 샘암종, 50\% 미만이면 저분화형으로 3 단계였으나, 두 단계 분화 등급에서 고분화형과 중분화형은 저등급, 저분화형은 고등급으로 분류한다[5,19].

\section{Location \\ $\square$ Cecum \\ Ascending colon \\ Hepatic flexure \\ Transverse colon \\ Splenic flexure \\ Descending colon \\ Sigmoid colon \\ Rectosigmoid junction \\ Rectum}

$\square$ Other: (specify:

해설: 위치는 ICD-O의 분류를 따른다[6]. 맹장의 길이는 대략 $6 \mathrm{~cm}$ 이고 에스자 결장의 길이는 $40 \mathrm{~cm}$ 이다. 직장은 항문연의 12-15 cm 상방부터 치상선의 1-2 cm 상방까지이다. 직장의 상부 $1 / 3$ 은 앞쪽과 양측면이 복막에 둘러싸여 있으며, 직장의 중 간 $1 / 3$ 은 앞쪽이 복막에 둘러싸여 있다. 직장의 하부 $1 / 3$ 은 복막에 둘러싸인 부분이 없다. 이번 개정에서 중복병변(overlapping lesion) 문항은 실제로 사용이 많지 않아 삭제하였다. 종양이 대장의 두 부분(subsite) 이상을 침범하였을 때는 종양의 중 심과 더 많이 침범한 부위를 판단하여 분류한다.

\section{Gross type}

Fungating/polypoid

$\square$ Ulcerofungating

$\square$ Ulceroinfiltrative

$\square$ Infiltrative

$\square$ Unclassifiable 
해설: 표재형(superficial type)은 현미경에서만 관찰할 수 있는 침윤 정도의 깊이로 정의되기 때문에 사용하기를 권고하지 않는다. 표재형으로 기술되던 폴립들 대부분이 융기형/폴립형(fungating/polypoid type)으로 분류될 수 있다. 만약 표재형을 쓴 다면, 일본의 육안 분류와 같이 점막이나 점막하층에 국한되어 있고, 종양의 두께가 주변 점막의 2 배 이하일 경우에만 쓰도 록 한다. 나머지 분류는 이전 판과 같이 융기형/폴립형, 궤양융기형(ulcerofungating), 궤양침윤형(ulceroinfiltrative), 침윤형(infiltrative), 미분류형(unclassifiable)이며, 위암의 보르만(Borrmann) 분류법과 동일하다.

\section{Tumor size}

$\times$ $\mathrm{cm}$

해설: 종양의 크기는 가장 긴 축의 길이와 이에 수직인 길이의 곱으로 표시한다. 종양의 깊이는 가장 두꺼운 곳에서 현미경 으로 측정한다.

\section{Depth of invasion}

Intramucosal carcinoma (pTis)

Tumor invades the submucosa (pT1)

Tumor invades the muscularis propria (pT2)

Tumor invades through the muscularis propria into pericolorectal tissue (pT3)

Tumor invades through the visceral peritoneum (pT4a)

Tumor directly invades or adheres to adjacent organs or structures (pT4b)

해설: AJCC 8판에 따르면 기저막 내부에 국한된 상피내암종(intraepithelial carcinoma)은 고등급이형성(high grade dysplasia) 과 동의어로 분류되며 pTis에 포함되지 않는 것으로 변경되었다. 고유판(lamina propria)을 침윤하나 점막근육(muscularis mucosae)을 넘지 않는 점막내암종(intramucosal carcinoma)이 전이 위험이 없는 암종인 pTis에 해당된다[4]. 점막내암종은 (1) 단일 세포나 세포군집이 기저막파열을 동반하며 고유판 침윤을 보일 때, (2) 섬유조직형성(desmoplasia)이나 염증세포침윤을 보이 는 고유판 변화가 있을 때, (3) 명백한 역형성을 가지는 세포가 심한 샘구조 이상(marked glandular crowding, excessive branching and budding)을 보여서 기저막파열이 의심되는 경우로 진단할 수 있다(Fig. 1A, B) [20]. 이에 비하여 고등급이형성은 세 포핵이 비정형을 보이면서 복잡한 샘구조이상(intraluminal cribriforming or necrosis, back-to-back fusion of multiple glands)이 있을 때 진단하며, 복잡한 샘구조이상 없이 중첩된 핵이 보일 때는 세포길이에 대한 비율에 상관없이 저등급이형성(low grade dysplasia)으로 분류한다(Fig. 1C) (pre-existing adenoma 참조). AJCC 8판에서는 대장결장의 상피내암종을 고등급이형성 과 동의어로 설명하면서 pTis에서 제외하였지만, AJCC 7판 이전에는 상피내암종이 pTis로 분류되어 있었고, 대장암을 제외 한 다른 소화기 암종에서는 여전히 pTis로 진단되고 있다[4]. 따라서 본 연구회에서는 혼동을 줄이기 위해 상피내암종이나 제자리샘암종(adenocarcinoma in situ)의 사용을 최소화하고, 고등급이형성과 점막내암종의 이분화된 진단을 사용하기를 권 장한다.

궤양에 의해 근육층이 소실된 부위에 종양이 있으면 장막하 침윤 $\mathrm{pT} 3$ 로 판정한다. 만일 종양과 장막의 거리가 $1 \mathrm{~mm}$ 미만 이고 염증이 동반되어 있으면 연속절편이나 추가 블록을 제작하여 주의깊게 검사한 후에도 장막 침범이 없으면 $\mathrm{pT} 3$ 로 한다 [4,21]. 다른 장기와 동일하게 $\mathrm{pT} 4$ 는 pT4a와 pT4b로 구분한다. 암세포가 복강으로 노출되어 있거나 암세포가 장막 면에 붙어 있으면서 중피세포의 증식이나 염증 등의 반응을 동반하는 경우 $\mathrm{pT} 4 \mathrm{a}$ 로 분류한다. 그러나 상행 및 하행 결장의 후부와 하부 직장과 같이 장막이 없는 부위에서는 pT4a를 적용할 수 없다. 암세포가 장막을 뚫고 인접한 장기를 침윤하였을 때는 pT4b로 구분하고 침범 장기를 기록한다. 직장암의 경우, 바깥항문조임근(external sphincter muscle) 침범은 pT3로 분류하지만 항문올 
림근(levator ani muscle) 침범이 있으면 pT4b로 한다.

림프관 혹은 정맥혈관 내에 국한된 암세포는 침윤 깊이에 해당하지 않으며 별도로 괄호안에 기록한다(invades proper muscle [involvement of subserosa by lymphatic emboli]). 주변점막이나 점막하층에 다수의 병변으로 나타나는 건너뛴 전이(skip metastasis)는 원격전이로 분류하지 않는다. 종양 주변에 농양이 동반되는 경우나 수술 전 항암치료 후 암세포 비동반(암세포가 없는) 점액 웅덩이가 관찰되는 경우는 예후 영향인자가 아닌 것으로 알려져 있으며, 이러한 조직학적 소견은 침윤 깊이를 평 가하는데 고려대상이 아니다[22-24].

[Endoscopic excision (Endoscopic submucosal dissection/polypectomy) or transanal excision]

Tumor invades the lamina propria with no extension through muscularis mucosae (pTis)

Tumor invades the submucosa (pT1)

For sessile lesion:

Distance of tumor from muscularis mucosae: $\mathrm{mm}$

For pedunculated lesion:

Haggitt level (head, neck, stalk, beyond stalk)

Distance of tumor invasion in stalk: $\mathrm{mm}$

해설: 악성 폴립(malignant polyp)은 육안적으로 샘종성 폴립모양이지만, 샘암종 세포가 점막하층 이상을 침범한 폴립을 일 컫는 것이며, 내시경적으로 절제된 폴립에서 (1) 고등급암(poorly differentiated carcinoma)의 존재, (2) 절제연과의 거리가 1 $\mathrm{mm}$ 이하, (3) 림프관/혈관 침범이 있는 경우 추가적인 수술이 요구된다. 점막하층 침윤 깊이도 림프절 전이의 위험을 예측할 수 있는 소견으로써 무경성 폴립에서 암의 침윤 깊이가 $1 \mathrm{~mm}(1,000 \mu \mathrm{m})$ 이상일 경우 림프절 전이 위험이 높다고 알려져 있 다[25,26].

본 소위원회에서는 점막하층 침윤 깊이의 측정오차를 줄이기 위하여 측정 방법에 대해 논의를 하였다. 유경성 폴립과 무 경성 폴립으로 구분하여, 유경성 폴립은 점막하층 침윤을 Haggitt level (head, neck, stalk, beyond stalk)로 구분하며[27,28], 폴 립의 목 부위(level 2)가 침윤을 측정하는 기준이 된다(Fig. 2A, B). 무경성 폴립의 점막하층 침윤에서는 점막근층이 보존된 경 우, 점막근층의 가장 하단 부위로부터 수직으로 측정한다. 점막근층이 불확실한 경우에는 주변 점막근층으로부터 자연스럽 게 연결되는 가상의 선을 그어 측정하도록 권장한다(Fig. 2C, D)[29].

\section{Resection margin \\ Proximal margin \\ $\square$ Free from carcinoma \\ $\square$ Involved by carcinoma \\ Distal margin \\ $\square$ Free from carcinoma \\ Involved by carcinoma \\ Circumferential margin (rectum only) \\ Free from carcinoma \\ $\square$ Involved by carcinoma}

Safety margin: proximal $\mathrm{cm}$, distal $\mathrm{cm}$, circumferential $\mathrm{cm}$ 
해설: 근위와 원위 절제연으로부터의 거리(safety margin)는 육안적으로 암종의 가장자리에서 가장 가까운 절제연까지의 길 이를 $\mathrm{cm}$ 단위로 표기한다. 직장암의 경우 환상절제연 평가는 장막으로 덮여 있지 않은 직장간막 절단면을 대상으로 하는 것 이며, 장막으로 덮여 있는 표면은 환상절제연이 아니므로 주의한다. 절제된 검체의 환상절제연을 확인하여 잉크 등으로 표 시한 후 종양이 가장 깊이 침윤한 곳을 포함한 절편을 채취한다. 현미경적으로 암종 세포의 침범이 있는지 여부를 평가하여 표기한다. 환상절제연과 암종(림프절, 신경, 혈관내 종양 포함) 사이의 거리가 $0.1 \mathrm{~cm}$ 이하인 경우 절제연을 양성으로 표기하 고, $0.1 \mathrm{~cm}$ 를 초과하는 경우에 음성으로 표기한다[3,4]. 직장암 외의 대장암은 환상절제연 평가가 필요하다고 판단한 경우에 만 표기한다.

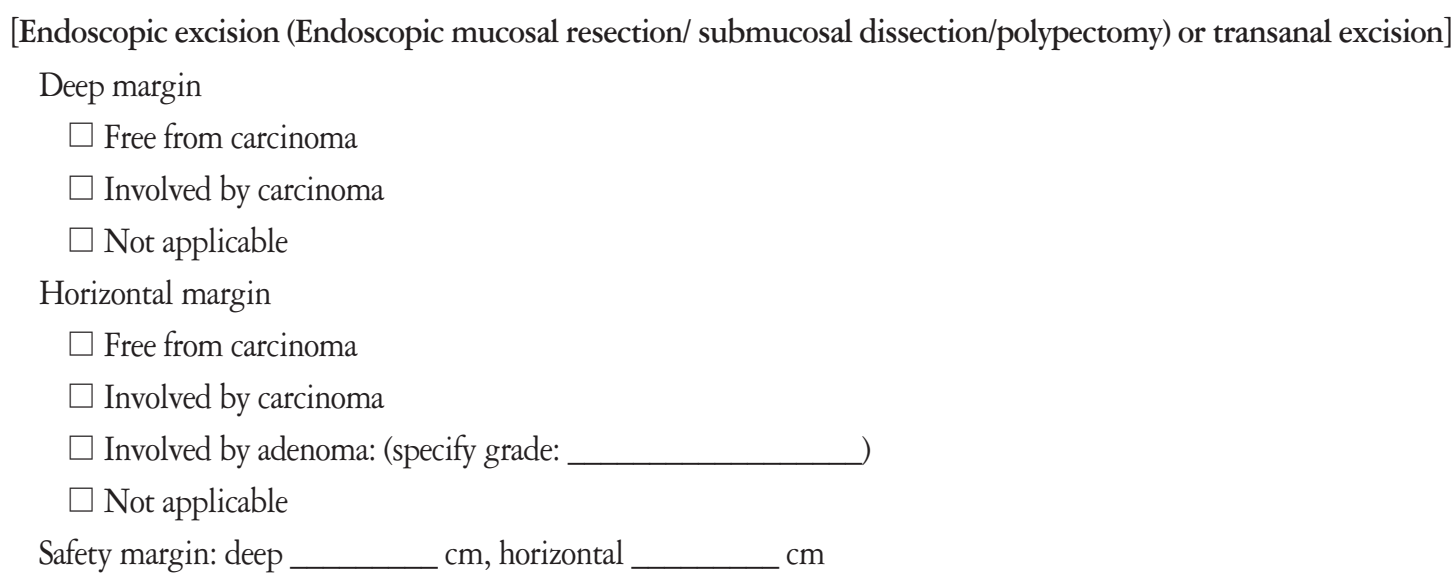

해설: 내시경절제(폴립절제, 점막절제, 점막하층박리) 및 항문경유절제를 포함한다. 현미경적으로 심부절제연(deep margin) 과 점막절제연(horizontal margin)을 검사하여 암종의 침범이 있는 경우 양성, 없는 경우 음성으로 표기한다. 점막절제연은 샘 종의 침범 여부를 표기한다. 조각절제된 검체 등 절제연의 평가가 불가능한 경우 평가할 수 없음으로 표기한다.

\section{Regional lymph node metastasis}

No metastasis in all___ regional lymph nodes $(\mathrm{pN} 0)$
Metastasis to ___ out of ___ regional lymph nodes
$\mathrm{pN} \_$r_

해설: 국소 림프절 전이의 진단은 원칙적으로 AJCC 8판을 따른다[4]. 정확한 예후 판정을 위해 12 개 이상의 림프절을 검사 하기를 권장하지만, 그보다 적은 수의 림프절을 검사하였더라도 모든 림프절에 전이가 없다면 $\mathrm{pN} 0$ 로 판정할 수 있다. 수술 전 항암, 방사선 치료를 한 경우에는 박리되는 림프절 수가 적을 수 있다. 국소 림프절 이외의 림프절로의 전이는 원격 전이 로 판정하고, 림프절 전이 숫자에는 포함시키지 않아야 한다.

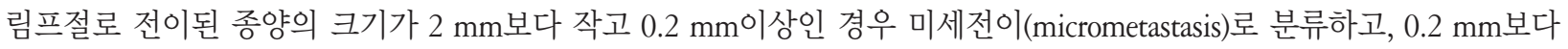
작은 경우 고립종양세포(isolated tumor cell)로 분류한다[4]. 미세전이가 있는 림프절은 림프절 전이가 있는 것으로 판단한다. 고립종양세포는 일부 병기에서 나쁜 예후와 관련이 있음이 알려져 있지만 AJCC 8판에서는 $\mathrm{pN} 0$ 로 평가하도록 권장하고 있 다[4]. 그러나, 이 부분은 논쟁의 여지가 있고, 실제 진단에서도 적용하기 어려운 점이 있다. 그래서, 우리는 기재사항 표준화 1 판에서와 같이 $\mathrm{H \& E}$ 슬라이드에서 발견된다면, 전이 종양의 크기가 $0.2 \mathrm{~mm}$ 보다 작은 고립종양세포도 림프절 전이로 판단 하고 전이 림프절 숫자에 포함하기를 권장한다. 
종양침전물(tumor deposit)은 장막하층, 장간막, 직장주변 조직에서 원발종양과 분리되어 관찰되는 림프절, 혈관, 신경 침범 이 아닌 종양 결절을 의미하며, 크기나 모양, 경계의 형태에 관련 없이 판단한다[4]. 이런 종양 결절 내부에 혈관 또는 신경 구조물이 관찰된다면 혈관 침범이나 신경 침범으로 판단해야 한다. 탄력섬유 특수염색(elastic stain)이나 smooth muscle actin 등의 면역조직화학 염색이 감별에 도움이 될 수 있다. 종양의 침윤 깊이에 상관없이, 림프절 전이가 없고 종양침전물이 있을 경우에는 $\mathrm{pN1c}$ 로 진단한다. 림프절 전이가 있는 경우 종양침전물은 림프절 개수에 포함하지 않는다. 수술 전 항암, 방사선 치료를 한 경우 종양퇴행에 의한 변화로 장막하 혹은 직장주변 조직의 종양이 종양침전물처럼 보이는 경우가 있으니 주의해 야 한다.

\section{Lymphatic (small vessel) invasion \\ $\square$ Not identified \\ $\square$ Present \\ Venous invasion}

$\square$ Not identified

$\square$ Present

$\square$ Intramural

$\square$ Extramural

해설: 림프관침범(lymphatic invasion)은 림프절 전이를 예측할 수 있는 인자이고[26], 정맥침범(venous invasion)은 잘 알려진 독립적 예후인자이다[30]. H\&E 염색에서 림프관(lymphatic vessel) 은 뒤당김인공물(retraction artifact)과 감별이 어려울 수 있 고, 이 경우 내피세포의 확인을 위해 D2-40 면역조직화학염색(immunohistochemistry)을 추가로 시행할 수 있다(Fig 3A). H\&E 염색으로 림프관과 혈관을 구별할 수 없는 경우가 흔하기 때문에 림프관, 모세혈관 및 모세혈관이후 세정맥과 같이 작은 맥 관을 침범한 경우는 림프관침범으로(Fig 3B), 근육층 또는 탄력판이 있는 큰 맥관을 침범한 경우는 정맥침범으로 간주한다 [31](Fig. 3C). 침범된 맥관 내에 적혈구가 관찰되더라도 맥관의 크기가 작은맥관(small vessel)이면 림프관침범으로 판정한다. 필요한 경우 탄력섬유를 확인하기 위한 특수염색이나 CD31, D2-40, smooth muscle actin과 같은 면역조직화학염색을 추가로 시행할 수 있다. 정맥침범중 벽외 정맥 침범은 대장직장암의 불량한 예후 및 간 전이와 연관된 독립적 예후 인자이므로 따로 표기하는 것을 권장한다[30].

\section{Perineural invasion}

Not identified

$\square$ Present

해설: 신경침범(perineural invasion)은 대장직장암에서 나쁜 예후를 나타내는 독립적인 예후인자로 알려져 있다[32]. 이는 병리보고서의 표준기재 사항이고 $\mathrm{H} \& \mathrm{E}$ 염색 슬라이드에서 평가한다. 신경침범의 기준은 명확하지 않으나, 종양세포가 신경 집(nerve sheath) 세 층 중 어느 하나라도 침범하거나 신경 둘레를 침범한 경우 신경침범으로 판정한다[33]. 종양세포가 신경 내에 존재하는 경우(intraneural invasion)도 신경침범에 포함시켜 기록한다. 


\section{Pre-existing adenoma \\ Absent \\ $\square$ Tubular/Tubulovillous/Villous adenoma \\ Low grade dysplasia/High grade dysplasia \\ $\square$ Sessile serrated lesion (Sessile serrated adenoma/polyp) \\ $\square$ Sessile serrated lesion (Sessile serrated adenoma/polyp) with dysplasia \\ $\square$ Traditional serrated adenoma \\ $\square$ Other (specify:}

해설: 대장암 전구병변의 두 가지 주요 카테고리에는 전형적 샘종(conventional adenoma)과 톱니모양병변(serrated lesion)이 있다[34]. WHO 분류에 따르면, 전형적 샘종은 형태학적으로 관형(tubular) 및 융모형(villous) 요소의 구성 비율에 따라 관형 (융모형 비율 25\% 미만), 관융모형(융모형 비율 25\%에서 $75 \%$ 사이), 융모형(융모형 비율 $75 \%$ 초과)의 3가지 샘종으로 나눌 수 있다[5]. 정의에 따르면, 모든 전형적 샘종은 상피의 이형성(dysplasia)을 나타내고, 이러한 이형성은 저등급(low-grade) 또 는 고등급(high-grade)으로 평가될 수 있다[5]. 고등급이형성은 복잡한 샘구조 이상(intraluminal cribriforming or necrosis, backto-back fusion of multiple glands), 핵의 다형성, 핵의 극성 소실, 핵 대 세포질 비율의 증가 등을 특징으로 한다(Fig 4A). 저등급 이형성의 특징으로는 비복잡성 구조, 층화(stratification), 길어진 모양의 과염성 핵, 유지된 세포 극성 등이 있다(Fig 4B). 고등 급이형성과 저등급이형성의 감별을 위해 가장 중요하고 필수적인 부분은 고유층의 침범이 없는 복잡한 샘구조 이상으로, 복 잡한 구조 이상 없이 세포학적 이상만 있을 경우는 고등급이형성으로 진단하지 않는다. 이전 판에서는 세포학적 이상이 있 을 경우에도 고등급이형성으로 진단하도록 권고하였고, 세 개 이상의 선구조가 고등급 소견을 보일 경우를 고등급이형성의 진단 기준으로 하였다. 이를 따르면 세포학적 이상만으로 고등급이형성을 진단하는 경우가 많아지고, 고등급이형성의 진단 에 가장 중요한 복잡한 샘구조 이상이 있음에도 불구하고 저등급이형성으로 진단하는 경우가 있었기 때문에, 복잡한 샘구조 이상을 고등급이형성의 필수 요소로 기술하였다. 하나의 전형적 샘종에서 고등급과 저등급 이형성이 함께 존재할 때에는 고 등급 이형성으로 진단한다[1].

WHO 분류에 따르면 톱니모양병변은 과증식 용종(hyperplastic polyp), 무경성톱니모양병변(sessile serrated lesion, SSL, 기존 용어 sessile serrated adenoma/polyp), 전통톱니모양샘종(traditional serrated adenoma)의 3가지로 나뉠 수 있다[5]. 그러나 톱니모 양병변의 분류법 및 진단기준은 계속 변하여 왔다[35,36]. 가장 최근의 2019년 WHO 분류법[5], 2012년 미국 전문가 패널 권 고사항[35] 및 2015년 영국의 가이드라인[36]을 종합적으로 고찰한 결과, 우리는 대장암의 기 존재 샘종(pre-existing adenoma) 으로서 톱니모양병변을 다음 3가지 용어 중 하나로 진단할 것을 권고한다: (1) 이형성이 없는 무경성톱니모양병변(SSL), (2) 이 형성이 있는 무경성톱니모양병변(SSL with dysplasia, SSLD), (3) 전통톱니모양샘종. 과증식 용종은 비전암성 양성 병변으로 취 급되므로 대장암의 기 존재 샘종으로서의 톱니모양병변 범주에는 포함하지 않도록 한다.

모든 무경성톱니모양병변은 전암성 병변으로 취급되며, 형태학적 이형성이 있을 수도 있고 없을 수도 있다. 이형성이 없 는 무경성톱니모양병변과 비교하여 이형성이 있는 무경성톱니모양병변은 암종으로 진행할 위험도가 높은 것으로 알려져 있다. 무경성톱니모양병변은 기저부까지 관찰되는 움(crypt) 내강의 톱니바퀴 모양(serration), 움의 수평방향 성장, 비대칭적 증식과 움의 바닥부분이 늘어나거나 가지치는 양상을 특징으로 한다(Fig. 4C). 무경성톱니모양병변은 전형적인 구조 이상을 보이는 움이 하나만 존재해도 진단 할 수 있다[5,35]. 무경성톱니모양병변의 이형성은 다양한 형태로 나타날 수 있으며, 하나 의 병변에서 여러가지의 형태를 보이기도 한다. 구조적으로 융모형 변화, 움 길이의 연장, 움 밀도의 증가, 격자형성, 움 내 톱 니의 감소 등을 보일 수 있고, 세포학적으로 전형적 샘종과 유사한 핵을 보이거나(장형 이형성: intestinal dysplasia) 원형의 핵 소체가 뚜렷한 핵을 보일 수 있다(톱니형 이형성: serrated dysplasia)[5]. 무경성톱니모양병변의 이형성에서는 MLH1의 발현 소실이 관찰되는 경우가 잦기 때문에, MLH1 면역염색이 무경성톱니모양병변의 이형성을 진단하는 데 도움이 될 수도 있다 [37]. 무경성톱니모양병변의 이형성을 등급화하는 체계는 아직 제시된 바가 없다. 따라서 우리는 대장암의 기 존재 샘종으로 서의 무경성톱니모양병변을 기술할 때에는 이형성의 여부만 명시하면 될 것으로 권고한다. 
모든 전통톱니모양샘종은 전암성 이형성 병변으로 취급되지만, 전통톱니모양샘종의 이형성을 분류하거나 등급화하는 체 계는 아직 제시된 바가 없다. 따라서 우리는 대장암의 기 존재 샘종으로서의 전통톱니모양샘종을 진단할 때 따로 이형성에 대한 언급 없이 전통톱니모양샘종만을 기술하면 될 것으로 권고한다. 전통톱니모양샘종은 평편하다가 예리하게 파인 형태의 내강 톱니바퀴 모양 및 풍부한 호산성 세포질을 가진 키가 큰 원주세포, 가늘어진 핵, 이소성 움 형성 등을 특징으로 한다(Fig. $4 \mathrm{D})$. 전통톱니모양샘종은 종종 다른 톱니모양병변이나 전형적 샘종을 동반한 혼합형 병변의 형태로 나타날 수 있다[38].

전형적 샘종 및 톱니모양병변을 모두 포함하여 두 가지 이상의 조직학적 아형의 조합으로 이루어진 전암성 병변일 경우에 는 혼합형 샘종(mixed adenoma)이라는 용어를 사용할 수 있다.

\section{Associated findings}

$\square$ Absent

$\square$ Tumor perforation (pT4a)

Perforation (non-tumor perforation)

$\square$ Metastasis to one site or organ without peritoneal metastasis (pM1a)

$\square$ Metastasis to two or more sites or organs without peritoneal metastasis (pM1b)

$\square$ Metastasis to the peritoneal surface with or without other site or organ metastasis (pM1c)

Specify metastatic sites or organs:

해설: 종양에 의한 천공은 대장암에서 나쁜 예후와 관련이 있는 것으로 알려져 있다[39]. 종양이 침범하지 않은 부위의 천 공도 복막염이나 패혈증을 유발할 수 있어 나쁜 예후와 관련이 있는 것으로 알려져 있으며, 주로 내강을 막는 종양의 근위부 에서 발생한다. 원격전이는 AJCC 8판에 따라, 복막 전이가 없으면서 한 위치 또는 한 장기로 전이하였을 경우 $\mathrm{pM1a}$, 복막전 이가 없으면서 둘 이상의 위치 또는 둘 이상의 장기로 전이하였을 경우 $\mathrm{pM} 1 \mathrm{~b}$ 로 분류하고, 복막전이가 있을 경우에는 $\mathrm{pM} 1 \mathrm{c}$ 로 분류한다[4].

\section{Separate lesions}
$\square$ Absent
$\square$ Adenoma
$\square$ Polyps
$\square$ GIST
$\square$ Ulcerative colitis/Crohn's disease
$\square$ Others
Specify: 


\title{
절제 대장의 선택 기재사항
}

\author{
Tumor budding \\ $\square$ Not identified \\ $\square$ Present \\ $\square \leq 4$ buds (low) \\ $\square$ 5-9 buds (intermediate) \\ $\square \geq 10$ buds (high) \\ $\square$ Cannot be assessed (specify:
}

해설: 종양 발아는 대장 및 직장암에서 잘 알려진 독립적인 나쁜 예후인자이다[40]. 종양발아는 다음과 같은 이유로 대장 및 직장암환자의 진료에 도움이 될 수 있다: (1) 내시경적으로 절제된 점막 절제술 검체에서 점막하 침윤(pT1)을 보이는 대장 및 직장암의 경우, 종양발아는 림프절 전이의 위험을 높일 수 있는 나쁜 예후인자이다[26,41,42]. 따라서 종양 발아를 보이는 환자는 잠재적인 수술절제 후보자로 볼 수 있다. (2) 높은 등급의 종양 발아를 보이는 병기 II(pT3N0 and pT4N0) 대장 및 직장 암 환자 군은 그렇지 않은 환자 군과 비교하여 더 나쁜 재발율을 보인다. 그러므로 높은 등급의 종양발아는 수술 후 보조요 법이 필요한 환자 군의 선별에 유용할 수 있다[43]. (3) 수술 전 생검 검체에서 종양발아의 존재는 전보조치료(수술전 항암치 료)에 대한 높은 위험성(저항성)을 보일 수 있는 직장암 환자군 선별에도 도움이 될 수 있다[44,45]. 그러므로, 점막절제술 $\mathrm{pT} 1$ 대장직장암 환자 및 병기 II의 대장직장암 환자의 경우, 종양발아에 관한 항목을 병리 진단지에 기재하는 것을 권장한다.

2016년에 열린 International Tumor Budding Consensus Conference (ITBCC)에서 다음과 같은 종양 발아의 평가기준을 제시 하였다[46]. (1) 종양발아는 1 개 혹은 4개 이하의 암세포 군들로 정의한다. (2) 종양발아는 모든 슬라이드를 검토한 후 침윤성 성장을 보이는 종양의 침습면 중 종양발아가 가장 잘 관찰되는 부위에서 측정하는 것을 권장한다 $\left(0.785 \mathrm{~mm}^{2}\right.$ 의 필드이거나, 대안 렌즈 FN 지름이 $20 \mathrm{~mm}$ 인 $\times 200$ 배 시야). (3) 종양발아는 $\mathrm{H \& E}$ 슬라이드에서 평가가 가능하다. Cytokeratin 면역염색은 $\mathrm{H \& E}$ 슬라이드에서 종양주변에 염증의 침윤이 심해 반응성 간질 세포와 구분이 힘든 경우 도움이 될 수 있고, 더 나은 재현 성과 관찰자간의 동의를 높일 수 있지만[47], 세포 자멸체 및 세포파편에도 염색되어 종양발아로 오인될 수 있다[46,48].

따라서 위에 기재한 종양 발아에 대한 3 가지 등급체계를 추천한다. 하지만, 종양 발아의 등급체계는 절대적인 기준이 아니 며, 종양발아의 개수를 측정-기재하는 것이 정보손실 등의 위험을 피할 수 있다. 드문 조직학적 유형을 보이는 경우(점액샘 암종, 인환세포암종, 미세유두샘암종, 그리고 수질암종) 종양 발아의 평가는 주의를 요한다[46]. 그러므로 종양 발아를 정확 하게 평가할 수 없는 경우 ‘cannot be assessed' 라고 기재하며 그 이유를 제시한다.

\section{Tumor border configuration}

해설: 종양의 경계부 배열에 대한 정보는 AJCC 8판과 College of American Pathologists (CAP) guidelines for colorectal cancers 에 모두 제시되어 있지 않고, $\mathrm{WHO}$ 분류에 간략하게 언급되고 있다[3-5]. 비록 종양의 경계부 배열에 대한 평가는 쉽고 $\mathrm{H \& E}$ 슬라이드로 평가할 수 있지만, 처음에 제시된 모호한 진단 기준 때문에 관찰자간의 재현성이 부족하다[49]. 이러한 이유로 이번 표준화 작업 진단지에서 제외하였다.

\section{Completeness of total mesorectal excision}

\section{Complete}

Nearly complete

Incomplete

$\square$ Cannot be determined 
해설: 전직장간막절제술(total mesorectal excision)이란 직장암을 제거할 때 직장간막의 바깥쪽 면인 느슨한 섬유성 결합조 직 내에서 림프절을 포함한 직장을 둘러싸는 연부조직을 한꺼번에 제거하는 것이다[50]. 전직장간막절제술을 시행하여 종 양이 침투한 가장자리 부위까지 적절히 절제하면 충분한 절제연이 확보되어 국소재발률이 감소한다는 것이 다수의 비무작 위연구를 통하여 밝혀진 바 있다. 육안검색 시 장막으로 덮여 있지 않은 측면에 대해 직장간막이 완벽히 절제되었는지 여부 를 가장 나쁜 곳을 기준으로 평가하고 점수화하여 보고한다[3,4,7]. 등급 부여의 기준은 아래와 같다.

Complete: 직장간막이 온전히 절제되어 원추형모양이 없는 매끈한 원통형. 절제면의 불규칙함이 거의 없음(결손이 있더라 도 결손의 깊이 $0.5 \mathrm{~cm}$ 이하).

Nearly complete: 직장간막 절단면이 불규칙함. 결손이 고유근층까지 확장되지 않음(결손분분의 깊이 $0.5 \mathrm{~cm}$ 초과). 직장 고 유근층이 노출되어 있지 않음(원위부 끝 올림근 부착 부위 제외).

Incomplete: 직장간막에 심각한 결손 있음. 직장 고유근층이 노출됨.

\section{Preoperative chemoradiotherapy}

$\square$ Yes $\quad \square$ No $\quad \square$ Not known

\section{If yes) Tumor regression grade}

$\square$ Grade 0: No viable cancer cells (complete response)

$\square$ Grade 1: Single cells or rare small groups of cancer cells (near-complete response)

Grade 2: Residual cancer with evident tumor regression, but more than single cells or rare small groups of cancer cells (partial response)

Grade 3: Extensive residual cancer with no evident tumor regression (poor or no response)

해설: 직장암의 치료 원칙은 근치적 절제 수술로 잔존하는 종양이 없는 상태를 이루는 것으로 국소 진행된 직장암은 골반 내 재발의 감소를 위한 보조 치료로 수술 전 항암화학방사선치료(chemoradiotherapy) 후 전직장간막절제술이 치료의 원칙이 다[51,52]. 수술 전 항암화학방사선치료의 종양반응등급(tumor regression grade)은 환자의 예후 및 재발 감소에 매우 중요한 요인이다[53-55]. 종양반응등급은 각 나라 및 기관마다 서로 다른 분류 및 등급체계를 사용하고 있으며, 이와 관련된 여러 연 구 논문들 역시 제각각 상이한 등급 체계를 적용하고 있어 임상 및 병리의사들간에 혼란을 주고 있다[4,53-59]. AJCC/CAP 종양반응등급 분류체계는 현재 National Comprehensive Cancer Network (NCCN) 가이드라인에서도 사용되고 있는 가장 많이 사용되고 있는 분류체계로서 종양반응등급 판정 시 림프절내 존재하고 있는 종양은 종양반응등급 판정에서 고려하지 않고 있다[4]. 대한병리학회 소화기병리학 연구회에서는 2006년 “대장암 병리보고서 기재사항 표준화”에서 제안한 바에 따라 치 료 효과를 등급화 된 숫자로 기술하지 않고, 퇴행 정도를 서술하는 것을 권장하였다[1]. 그러나, 서술적 판단기준 역시 병리 의사 간 차이가 존재하고 있고, 이러한 서술적 분류체계가 널리 사용되고 있지 않아 기존의 숫자화 된 등급체계와 혼란을 주 고 있다. 이를 극복하고자 소화기병리학 연구회에서는 널리 통용될 수 있는 새로운 종양반응등급을 8판 AJCC 및 CAP cancer protocol을 기반으로 분류하였다(Fig. 5)[3,4].

종양의 종양반응 등급판정을 위하여 육안적으로 종양이 구분되고 주변 연부조직까지 침윤한 경우 최소한 4 개 이상의 대 표적 절편을 포매 하여야 한다. 섬유화가 진행되어 있어 주변지방조직 침윤이 확실하지 않거나, 정상 점막 아래에 섬유화가 있는 검체 및 $2.0 \mathrm{~cm}$ 이하의 병변은 상, 하 방향으로 $0.4 \mathrm{~cm}$ 간격으로 절제 후 병변 전체를 포매하는 조직구축학적 검사를 권 장한다. 수술 전 항암화학방사선치료 후 적출된 검체의 특징은 종양세포가 많은 양의 섬유화로 치환되며, 포말탐식세포를 포함하여 많은 양의 염증세포가 침윤되어 있다. 또한 부종, 점액변성, 괴사 등을 볼 수 있고 종양세포가 없는 점액 웅덩이 (acellular mucin) 등을 관찰할 수 있다. 종양세포 없이 점액소 혹은 괴사조직만 관찰될 경우 병리학적으로는 완전 퇴행 반응 (complete regression)으로 판정할 수 있다. 종양세포와 거대세포 및 섬유모세포와의 감별이 어려울 경우, 계단식 절편을 시행 하거나, 점액염색 혹은 cytokeratin과 같은 면역조직화학염색 등을 시행함으로써 종양반응등급 분류 판정에 도움을 받을 수 있다. 


\title{
EGFR immunohistochemistry
}

해설: 그 동안의 연구들에 따르면 대장암의 25\%-90\%에서 epidermal growth factor receptor (EGFR) 단백질의 발현이 면역조 직화학염색에서 관찰되었다[60-64]. 초기에 발표된 연구들에서는 대장암에서 면역조직화학염색을 통한 EGFR 발현 증거가 cetuximab 이나 panitumumab과 같은 EGFR 표적 치료제 적용을 위한 필수적인 요소라고 생각하였다[65]. 하지만, 후속 연구 들에서 EGFR 면역조직화학염색 발현 정도와 이들 약물에 대한 치료반응 사이에 상관 관계가 없음이 밝혀졌다[66-68]. 따라 서, 현재 면역조직화학염색에 의한 EGFR 발현은 EGFR 표적 치료제 반응의 예측인자로 간주되지 않으며, EGFR 표적 치료 제에 대한 최근 연구들에서는 EGFR 발현을 치료 적용 기준에 포함시키지 않고 있다. 국내에서는 대장암 환자에서 EGFR 표 적 치료제를 적용하기 위해서는 EGFR 발현이 확인되어야 한다는 건강보험심사평가원의 요양급여 적용기준에 따라 EGFR 면역조직화학염색이 아직까지 시행되고 있지만, 면역조직화학염색 상 EGFR의 발현이 EGFR 표적 치료제의 치료효과를 정 확하게 예측하는지에 대해서는 근거가 없다.

\author{
DNA mismatch repair immunohistochemistry \\ MLH1: $\square$ Positive (Retained expression) \\ $\square$ Negative (Loss of expression) \\ MSH2: $\square$ Positive (Retained expression) \\ $\square$ Negative (Loss of expression) \\ PMS2: $\square$ Positive (Retained expression) \\ $\square$ Negative (Loss of expression) \\ MSH6: $\square$ Positive (Retained expression) \\ $\square$ Negative (Loss of expression) \\ Summary: DNA mismatch repair deficiency (was/was not) observed
}

해설: 대장암 조직에서 DNA mismatch repair (MMR) 단백질에 대한 면역조직화학염색은 4가지 MMR 유전자들 (MLH1, $\mathrm{MSH} 2, \mathrm{MSH} 6$ 및 PMS2) 중 하나에서의 배선 돌연변이(germline mutation) 또는 프로모터 과메틸화(promoter CpG island hypermethylation)에 의해 발생하는 MMR 결핍(MMR deficiency)를 판정하기 위한 매우 간단하고 유용한 방법이다[69-71]. $\mathrm{MMR}$ 결핍은 DNA 현미부수체(microsatellite) 반복 서열이 유전체 전반적으로 길이 변화를 보이는 것을 특징으로 하는 현미 부수체 불안정성(high level of microsatellite instability, MSI-H)의 고유한 원인이다[72]. MLH1은 PMS2와 이합체(dimer)를 이 루어 DNA MMR 기능을 수행하므로, 대장암에서 MLH1 유전자의 돌연변이 또는 프로모터 메틸화가 발생하게 되면 MLH1 및 PMS2의 면역조직화학적 발현은 모두 음성 소견을 보인다[69,70]. 마찬가지로, $\mathrm{MSH}$ 는 MSH6와 이합체를 이루기 때문에, $\mathrm{MSH} 2$ 에 돌연변이를 가지는 대장암은 $\mathrm{MSH} 2$ 및 MSH6 면역조직화학 검사에서 모두 음성을 나타낸다[69,70]. 그러나 대장암 에서 PMS2 또는 MSH6 유전자의 돌연변이가 발생하면, MLH1 및 MSH2의 발현은 유지되고 PMS2 또는 MSH6의 발현만이 소실된다[69,70].

MMR 양성을 면역조직화학염색을 이용하여 판정하기 위해서는 핵에 염색된 양상이 나타나야만 한다. MMR 단백질 중 적 어도 하나가 종양세포의 핵에서 발현 소실이 되어 있다면 MMR 결핍으로 판정할 수가 있다(Fig. 6).

MMR 면역조직화학염색은 현재 대장암에서 린치증후군 또는 산발성 MSI-H 대장암의 선별검사를 위한 조직병리학적 도 구로 확립되어 있다[69-71]. MMR 결핍(또는 MSI-H)가 대장암에서 좋은 예후와 유의한 관련이 있는 한편, 5-fluorouracil (5$\mathrm{FU})$ 를 기반으로 하는 보조적 항암화학요법에 대한 저항성과 관련성이 있음이 메타분석 결과를 포함한 이전의 많은 데이터 들에 의하여 입증된 바 있다[72-74]. 또한 최근의 연구들에 따르면 MMR 결핍(또는 MSI-H)가 대장암을 포함한 여러 고형암 에서 PD-1 차단을 사용한 항암면역치료의 중요한 치료반응 예측 인자임이 입증되고 있다[75,76]. 따라서 면역조직화학염색 을 통한 MMR 평가 혹은 DNA 분석을 이용한 MSI 평가는 외과적으로 절제된 모든 대장암 표본에 대하여 병리 보고서를 통 하여 그 결과를 공식적으로 보고하는 것이 요망된다. 


\section{Immunoscore}

해설: 종양침윤림프구(tumor-infiltrating lymphocyte, TIL)가 대장암 환자의 예후와 밀접한 관련이 있다는 사실이 다수의 연 구들에 의하여 일관되게 입증되었다[77]. 구체적으로는 대장암에서 TIL의 수치가 높을수록 대장암 환자의 예후가 좋다는 것 인데, 몇몇 연구에서는 TIL이 TNM 병기 및 현미부수체 불안정성(microsatellite instability, MSI)과 독립적으로 유의한 예후적 영향이 있다고 주장하였다[78,79]. 대장암에서 예후와 관련된 TIL의 구성은 세포독성 T 림프구가 주를 이루고 있으며 따라 서 $\mathrm{CD} 3$ 및 $\mathrm{CD} 8$ 면역조직화학염색을 시행하는 것이 TIL 측정의 근간을 이루고 있다[78,80].

이들 연구결과에 근거하여 ‘Immunoscore’라는 표준화된 분류체계를 도입하려는 시도가 이루어지고 있으며 2012년에 Jerome Galon 박사가 주도하는 다국적 연구자들의 태스크포스 컨소시엄이 이루어져 immunoscore와 관련된 컨센서스를 이루 기 위한 사업이 추진되고 있다(http://www.immunoscore.org)[80,81]. 대장암에서 immunoscore를 판정하기 위한 단계는 다음과 같다: (1) 대표 종양 절편을 선택, (2) 선택된 종양 절편에 대하여 $\mathrm{CD} 3$ 및 $\mathrm{CD} 8$ 면역염색을 시행, (3) 종양침윤경계부(invasive margin, $\mathrm{IM}$ ) 및 종양중심부(tumor center, TC) 두 영역에 대하여 각각의 $\mathrm{CD} 3$ 양성 세포 및 $\mathrm{CD} 8$ 양성 세포의 밀도를 구함, (4) 이 로써 산출되는 4가지 변수 $(\mathrm{CD} 3+\mathrm{IM}, \mathrm{CD} 3+\mathrm{TC}, \mathrm{CD} 8+\mathrm{IM}$, and $\mathrm{CD} 8+\mathrm{TC})$ 각각에 대하여 high 혹은 low로 분류하는 이분 범 주화를 시행, (5) 4가지 변수의 결과를 종합하여 최종 immunoscore를 산출(예: 'high'가 하나도 없으면 I0, 'high'가 하나만 있으 면 I1, 'high'가 둘 있으면 I2, 'high'가 셋 있으면 I3, 넷 모두 ‘high'이면 I4).

비록 immunoscore가 대장암에서 예후적 유의성을 지닌다는 강력한 증거들이 존재하지만, immunoscore의 적응증, 평가법 및 분류법의 측면에 있어서 전세계적으로 잘 합의된 컨센서스를 이루지는 못하고 있다. 현행 immunoscore의 가장 중요한 제 한점 가운데 하나는 $\mathrm{CD} 3$ 혹은 $\mathrm{CD} 8$ 양성 세포의 밀도를 high 및 low로 범주화시키기 위한 기준값을 어떻게 설정할 것이냐는 문제가 있다. 디지털 이미지를 통한 자동화된 형태계측방법(automated analysis)이 향후 표준화된 평가기준을 마련하는데 도 움이 될 수 있을 것이다. 결론적으로 대장암에서 immunoscore의 평가 및 보고는 임상적인 필요성 및 기관의 수행능력 등에 기반하여 권장될 수는 있으나 현재 병리보고서의 필수 기재사항에는 포함하지 않았다.

\section{Microsatellite instability (MSI) \\ Summary: $\square$ MSI-stable (MSS) \\ MSI-low (MSI-L) \\ MSI-high (MSI-H)}

해설: 현미부수체불안정은 불일치복구 유전자(mismatch repair gene; MLH1, MSH2, MSH6, PMS2)의 태생적 돌연변이 (germline mutation) 또는 MLH1 유전자 프로모터의 과메틸화에 의한 MMR 결핍(MMR deficiency)으로 염기서열 내 현미부수 체의 길이가 변화하는 현상이다[72]. NCCN 가이드라인과 미국 대장암 바이오마커 가이드라인에서는 현미부수체불안정은 린치증후군의 선별을 위하여 모든 대장암에서 시행하는 것을 권장한다[82]. 또한, 대장암에서 현미부수체불안정은 좋은 예 후와 연관되며, 5-FU 기반의 보조항암화학요법에 대한 저항성과 연관된다[83,84]. 최근의 연구에서 현미부수체불안정은 $\mathrm{PD} 1$ 억제제를 이용한 종양면역치료의 치료반응 예측인자로 입증되었다[75,85].

현미부수체불안정을 측정하는 표준검사법(gold standard)은 모세관전기이동(capillary electrophoresis)를 이용하여 정상조직 대비 종양조직에서의 핵산증폭산물의 길이변화를 비교하는 방법이다. 두 개의 모노뉴클레오타이드 마커(BAT25, BAT26), 세 개의 다이뉴클레오타이드 마커 (D5S346, D2S123, D17S250)를 검사하는 베데스다 패널(Bethesda panel)과, 다섯 개의 모노 뉴클레오타이드 마커(NR-27, NR-21, NR-24, BAT-25, BAT-26)를 검사하는 준단일체(quasimonomorphic) 모노뉴클레오타이 드 마커패널을 사용할 수 있다[86,87]. 준단일체 모노뉴클레오타이드 마커패널의 경우 실시간 중합효소연쇄반응(real-time PCR) 기법으로도 검사가 가능하다. 현미부수체 고불안정형(microsatellite instability-high, MSI-high, MSI-H)을 보이는 경우 불일치복구 단백질에 대한 면역조직화학검사를 추가적으로 시행하여 린치증후군을 선별해야 한다. MLH1의 발현이 소실된 MSI-H 대장암에서 BRAF V600E 돌연변이가 양성인 경우 린치증후군을 배제할 수 있다[88]. 현미부수체불안정은 불일치복 구결핍(mismatch repair deficiency, dMMR)과 상응하므로 모세관전기영동 검사법을 사용할 수 없는 경우 불일치복구 단백질 
인 MLH1, MSH2, MSH6, PMS2에 대한 면역조직화학검사법으로 갈음할 수 있다.

베데스다 패널은 다섯 개의 현미부수체 마커 중 2개 이상의 마커가 불안정을 보이는 경우 'MSI-H'이라고 보고하며, 현미부 수체 마커 중 한 개의 마커가 불안정을 보이는 경우 '현미부수체 저불안정형(microsatellite intability-low, MSI-low, MSI-L)'이라 고 보고한다. 현미부수체 마커 중 단 하나에서도 불안정이 관찰되지 않는 경우 '현미부수체안정형(microsatellite stable, MSS)' 라고 보고한다[87]. Quasimonomorphic mononucleotide marker의 경우 MSI-H의 기준을 마커 3개 이상이 불안정을 보일 때로 해야 하는지, 마커 2개 이상이 불안정을 보일 때로 해야 하는지에 대하여 아직 이견이 있다[89,90].

\section{KRAS mutation analysis}

$\square$ No mutation detected

$\square$ Mutation detected (specify: example: $\quad$ c.35G $\geq$-A,p.Gly12Asp

\section{NRAS mutation analysis}

$\square$ No mutation detected

$\square$ Mutation detected (specify: example: c.35G $\geq$ A, p.Gly12Asp

해설: KRAS 유전자와 NRAS 유전자 각각의 exon $2,3,4$ 에 대하여 돌연변이의 유무를 검사하는 것을 확장형 $R A S$ 돌연변이 검사라고 한다[82,91]. 전이성 대장암에서 표피성장인자수용체 차단제(EGFR blocker)의 단일요법/병용요법은 환자의 생존 기간을 유의하게 증가시킨다고 알려져 있으나, KRAS 유전자의 exon 2,3,4와 NRAS 유전자의 exon 2, 3, 4에 점돌연변이가 존 재할 경우 표피성장인자수용체 차단제에 저항성을 띠는 것으로 알려져 있다. 따라서 전이성 대장암 환자에서 표피성장인자 수용체 차단제를 사용하려는 경우 반드시 KRAS exon 2,3,4와 NRAS exon 2,3,4를 모두 포함하는 확장형 RAS 돌연변이검사 (extended RAS mutation test)를 시행할 것을 유럽종양학회(European Society for Medical Oncology, ESMO) 가이드라인, NCCN 가이드라인, 미국 대장암 바이오마커 가이드라인 등에서 권장하고 있다[82,91-93]. 한편, KRAS 유전자의 exon 2의 점돌연변 이는 대장암의 불량한 예후와 연관된 것으로 알려져 있다[94-98].

확장형 RAS돌연변이검사는 생어시퀀싱(Sanger sequencing), 파이로시퀀싱(pyrosequencing), 실시간 중합효소연쇄반응(realtime PCR) 등이 사용될 수 있으며, 차세대시퀀싱 고형암 패널을 이용하여 검사가 가능하게 되었다. KRAS, NRAS 유전자의 exon $2,3,4$ 에 대하여 점돌연변이의 유무와 검출된 점돌연변이의 종류를 보고하여야 하며, 유전자 명명법은 공인된 명명법 을 사용해야 한다.

\section{BRAF mutation analysis}

$\square$ No mutation detected

BRAF V600E (c.1799T > A) mutation

$\square$ Other BRAF mutation (specify:

해설: BRAF V600E 돌연변이는 MLH1 프로모터의 과메틸화를 보이는 현미부수체불안정 대장암 환자의 3 분의 2 가량에서 발견되는 것으로 보고되고 있으나, 린치증후군 환자에서는 BRAF V600E 돌연변이가 관찰되지 않는다[99]. 따라서 현미부수 체불안정 대장암 환자에서 $B R A F \mathrm{~V} 600 \mathrm{E}$ 돌연변이 검사가 양성인 경우 린치증후군을 배제할 수 있으므로 불일치복구 유전 자에 대한 유전자 검사를 시행하지 않아야 한다[88].

현미부수체불안정과 BRAF V600E 돌연변이를 동시에 가진 환자군(MSI/BRAF-MT)은 매우 양호한 예후를 보이는 것으로 보고되었고, 현미부수체불안정 음성 대장암에서 BRAF V600E 돌연변이를 보이는 환자군(MSS/BRAF-MT)만 불량한 예후를 
보이는 것으로 보고되었다[95-98]. 따라서 대장암 환자의 예후 예측을 위해서 $B R A F$ 돌연변이 검사는 현미부수체불안정검 사와 함께 사용되어야 한다. 전이성 대장암에서 행해진 두 연구에서 BRAF V600E 돌연변이는 불량한 예후와 연관되었다 $[98,100]$.

표피성장인자수용체 차단제 치료에 있어 $B R A F \mathrm{~V} 600 \mathrm{E}$ 돌연변이가 불량한 치료 반응과 연관된다는 보고가 있으나, BRAF V600E 돌연변이가 독립적인 예측인자인지에 대해서는 논란이 계속되고 있다[101,102]. 2017년 NCCN guideline에서는 표피 성장인자수용체 차단제의 적응증이 되는 전이성 대장암 환자에서 $B R A F \mathrm{~V} 600 \mathrm{E}$ 돌연변이 검사를 권고하고 있으나, ASCP guideline과 ESMO guideline에서는 권고하지 않고 있는 실정이다[82,91].

생어시퀀싱(Sanger sequencing), 파이로시퀀싱(pyrosequencing), 실시간 중합효소연쇄반응(real-time PCR) 등이 사용될 수 있 으며, 차세대시퀀싱 고형암 패널을 이용하여 검사가 가능하게 되었다. BRAF exon $15 \mathrm{~V} 600 \mathrm{E}$ 돌연변이의 존재 유무를 보고하 여야 하며, 유전자 명명법은 공인된 명명법을 사용해야 한다.

대한병리학회 소화기병리학연구회 대장암 기재사항 표준화 소위원회

위원: 김백희, 김준미, 강경훈, 장희진, 강동욱, 김정호, 배정모, 서안나, 박호성, 강윤경, 이경화, 조미연, 도인구, 이혜승,

장희경, 박도윤, 강효정, 손진희, 장미수, 정은선, 진소영, 유은실, 한혜승, 김윤화.

책임저자: 김준미 (인하대학교 병원)

\section{REFERENCES}

1. Chang HJ, Park CK, Kim WH, et al. A standardized pathology report for colorectal cancer. Korean J Pathol 2006; 40: 193-203.

2. Ministry of Health and Welfare. Annual report of cancer statistics in Korea in 2015. Sejong: Ministry of Health and Welfare, 2017.

3. Kakar S, Shi C, Berho ME, et al. Protocol for the examination of specimens from patients with primary carcinoma of the colon and rectum, version 4.0.0.0. Illinois: College of American Pathologists, 2017.

4. Amin MB, Edge S, Greene F, et al. AJCC cancer staging system. 8th ed. New York: Springer, 2017.

5. WHO Classification of Tumours Editorial Board. WHO classification of tumours: digestive system tumours. 5th ed. Geneva: World Health Organization, 2019.

6. Fritz AG, Percy C, Jack A, et al. International classification of diseases for oncology (ICD-O). 3rd ed. 1st rev. Lyon: International Agency for Research on Cancer, 2013.

7. Langman G, Loughrey M, Shepherd N, Quirke P. Association of Coloproctology of Great Britain \& Ireland (ACPGBI): guidelines for the management of cancer of the colon, rectum and anus (2017) - pathology standards and datasets. Colorectal Dis 2017; 19 Suppl 1: 74-81.

8. Nagtegaal I, Gaspar C, Marijnen C, Van De Velde C, Fodde R, Van Krieken H. Morphological changes in tumour type after radiotherapy are accompanied by changes in gene expression profile but not in clinical behaviour. J Pathol 2004; 204: 183-92.

9. Verdu M, Roman R, Calvo M, et al. Clinicopathological and molecular characterization of colorectal micropapillary carcinoma. Mod Pathol 2011; 24: 729-38.

10. Lee HJ, Eom DW, Kang GH, et al. Colorectal micropapillary carcinomas are associated with poor prognosis and enriched in markers of stem cells. Mod Pathol 2013; 26: 1123-31.

11. Nassar H. Carcinomas with micropapillary morphology: clinical significance and current concepts. Adv Anat Pathol 2004; $11: 297-303$.

12. $\mathrm{Xu} \mathrm{F}, \mathrm{Xu} \mathrm{J}$, Lou Z, et al. Micropapillary component in colorectal carcinoma is associated with lymph node metastasis in T1 and T2 Stages and decreased survival time in TNM stages I and II. Am J Surg Pathol 2009; 33: 1287-92.

13. Haupt B, Ro JY, Schwartz MR, Shen SS. Colorectal adenocarcinoma with micropapillary pattern and its association with lymph node metastasis. Mod Pathol 2007; 20: 729-33.

14. Jakubowska K, Guzinska-Ustymowicz K, Pryczynicz A. Invasive micropapillary component and its clinico-histopathological significance in patients with colorectal cancer. Oncol Lett 2016; 12: 1154-8.

15. Tuppurainen K, Makinen JM, Junttila O, et al. Morphology and microsatellite instability in sporadic serrated and non-serrated colorectal cancer. J Pathol 2005; 207: 285-94.

16. Patai AV, Molnár B, Tulassay Z, Sipos F. Serrated pathway: alternative route to colorectal cancer. World J Gastroenterol 2013; 19: 607-15. 
17. Mäkinen MJ. Colorectal serrated adenocarcinoma. Histopathology 2007; 50: 131-50.

18. Barresi V, Reggiani Bonetti L, Ieni A, Domati F, Tuccari G. Prognostic significance of grading based on the counting of poorly differentiated clusters in colorectal mucinous adenocarcinoma. Hum Pathol 2015; 46: 1722-9.

19. Bosman FT, Carneiro F, Hruban RH, Theise ND. WHO classification of tumours of the digestive system. 4th ed. Lyon: International Agency for Research on Cancer, 2010.

20. Kojima M, Shimazaki H, Iwaya K, et al. Intramucosal colorectal carcinoma with invasion of the lamina propria: a study by the Japanese Society for Cancer of the Colon and Rectum. Hum Pathol 2017; 66: 230-7.

21. Panarelli NC, Schreiner AM, Brandt SM, Shepherd NA, Yantiss RK. Histologic features and cytologic techniques that aid pathologic stage assessment of colonic adenocarcinoma. Am J Surg Pathol 2013; 37: 1252-8.

22. Uehara K, Nakanishi Y, Shimoda T, Taniguchi H, Akasu T, Moriya Y. Clinicopathological significance of microscopic abscess formation at the invasive margin of advanced low rectal cancer. Br J Surg 2007; 94: 239-43.

23. Smith KD, Tan D, Das P, et al. Clinical significance of acellular mucin in rectal adenocarcinoma patients with a pathologic complete response to preoperative chemoradiation. Ann Surg 2010; 251: 261-4.

24. Kang CM, Lim SB, Hong SM, et al. Prevalence and clinical significance of cellular and acellular mucin in patients with locally advanced mucinous rectal cancer who underwent preoperative chemoradiotherapy followed by radical surgery. Colorectal Dis 2016; 18: O10-6.

25. Kitajima K, Fujimori T, Fujii S, et al. Correlations between lymph node metastasis and depth of submucosal invasion in submucosal invasive colorectal carcinoma: a Japanese collaborative study. J Gastroenterol 2004; 39: 534-43.

26. Bosch SL, Teerenstra S, de Wilt JH, Cunningham C, Nagtegaal ID. Predicting lymph node metastasis in pT1 colorectal cancer: a systematic review of risk factors providing rationale for therapy decisions. Endoscopy 2013; 45: 827-34.

27. Haggitt RC, Glotzbach RE, Soffer EE, Wruble LD. Prognostic factors in colorectal carcinomas arising in adenomas: implications for lesions removed by endoscopic polypectomy. Gastroenterology 1985; 89: 328-36.

28. Kikuchi R, Takano M, Takagi K, et al. Management of early invasive colorectal cancer: risk of recurrence and clinical guidelines. Dis Colon Rectum 1995; 38: 1286-95.

29. Watanabe T, Muro K, Ajioka Y, et al. Japanese Society for Cancer of the Colon and Rectum (JSCCR) guidelines 2016 for the treatment of colorectal cancer. Int J Clin Oncol 2018; 23: 1-34.

30. Betge J, Pollheimer MJ, Lindtner RA, et al. Intramural and extramural vascular invasion in colorectal cancer: prognostic significance and quality of pathology reporting. Cancer 2012; 118: 628-38.

31. Kim WH, Park CK, Kim YB, et al. A standardized pathology report for gastric cancer. Korean J Pathol 2005; 39: 106-13.

32. Liebig C, Ayala G, Wilks J, et al. Perineural invasion is an independent predictor of outcome in colorectal cancer. J Clin Oncol 2009; $27: 5131-7$.

33. Liebig C, Ayala G, Wilks JA, Berger DH, Albo D. Perineural invasion in cancer: a review of the literature. Cancer 2009; 115: 3379-91.

34. Gibson JA, Odze RD. Pathology of premalignant colorectal neoplasia. Dig Endosc 2016; 28: 312-23.

35. Rex DK, Ahnen DJ, Baron JA, et al. Serrated lesions of the colorectum: review and recommendations from an expert panel. Am J Gastroenterol 2012; 107: 1315-29.

36. Bateman AC, Shepherd NA. UK guidance for the pathological reporting of serrated lesions of the colorectum. J Clin Pathol 2015; 68: 585-91.

37. Liu C, Walker NI, Leggett BA, Whitehall VL, Bettington ML, Rosty C. Sessile serrated adenomas with dysplasia: morphological patterns and correlations with MLH1 immunohistochemistry. Mod Pathol 2017; 30: 1728-38.

38. Chetty R, Hafezi-Bakhtiari S, Serra S, Colling R, Wang LM. Traditional serrated adenomas (TSAs) admixed with other serrated (so-called precursor) polyps and conventional adenomas: a frequent occurrence. J Clin Pathol 2015; 68: 270-3.

39. Anwar MA, D'Souza F, Coulter R, Memon B, Khan IM, Memon MA. Outcome of acutely perforated colorectal cancers: experience of a single district general hospital. Surg Oncol 2006; 15: 91-6.

40. Mitrovic B, Schaeffer DF, Riddell RH, Kirsch R. Tumor budding in colorectal carcinoma: time to take notice. Mod Pathol 2012; 25: 1315-25.

41. Choi DH, Sohn DK, Chang HJ, Lim SB, Choi HS, Jeong SY. Indications for subsequent surgery after endoscopic resection of submucosally invasive colorectal carcinomas: a prospective cohort study. Dis Colon Rectum 2009; 52: 438-45.

42. Ueno H, Mochizuki H, Hashiguchi Y, et al. Risk factors for an adverse outcome in early invasive colorectal carcinoma. Gastroenterology 2004; 127: 385-94.

43. Wang LM, Kevans D, Mulcahy H, et al. Tumor budding is a strong and reproducible prognostic marker in T3N0 colorectal cancer. Am J Surg 
Pathol 2009; 33: 134-41.

44. Giger OT, Comtesse SC, Lugli A, Zlobec I, Kurrer MO. Intra-tumoral budding in preoperative biopsy specimens predicts lymph node and distant metastasis in patients with colorectal cancer. Mod Pathol 2012; 25: 1048-53.

45. Rogers AC, Gibbons D, Hanly AM, et al. Prognostic significance of tumor budding in rectal cancer biopsies before neoadjuvant therapy. Mod Pathol 2014; 27: 156-62.

46. Lugli A, Kirsch R, Ajioka Y, et al. Recommendations for reporting tumor budding in colorectal cancer based on the International Tumor Budding Consensus Conference (ITBCC) 2016. Mod Pathol 2017; 30: 1299-311.

47. Koelzer VH, Zlobec I, Berger MD, et al. Tumor budding in colorectal cancer revisited: results of a multicenter interobserver study. Virchows Arch 2015; 466: 485-93.

48. Koelzer VH, Assarzadegan N, Dawson H, et al. Cytokeratin-based assessment of tumour budding in colorectal cancer: analysis in stage II patients and prospective diagnostic experience. J Pathol Clin Res 2017; 3: 171-8.

49. Jass JR, Love SB, Northover JM. A new prognostic classification of rectal cancer. Lancet 1987; 1: 1303-6.

50. Bosch SL, Nagtegaal ID. The importance of the pathologist's role in assessment of the quality of the mesorectum. Curr Colorectal Cancer Rep 2012; 8: 90-8.

51. Aklilu M, Eng C. The current landscape of locally advanced rectal cancer. Nat Rev Clin Oncol 2011; 8: 649-59.

52. Bibeau F, Rullier A, Jourdan MF, et al. Locally advanced rectal cancer management: which role for the pathologist in 2011? Ann Pathol 2011; 31 : 433-41.

53. Dhadda AS, Dickinson P, Zaitoun AM, Gandhi N, Bessell EM. Prognostic importance of Mandard tumour regression grade following pre-operative chemo/radiotherapy for locally advanced rectal cancer. Eur J Cancer 2011; 47: 1138-45.

54. Mihaylova I, Parvanova V, Velikova C, Kurteva G, Ivanova D. Degree of tumor regression after preoperative chemo-radiotherapy in locally advanced rectal cancer-Preliminary results. Rep Pract Oncol Radiother 2011; 16: 237-42.

55. Vallböhmer D, Bollschweiler E, Brabender J, et al. Evaluation of histological regression grading systems in the neoadjuvant therapy of rectal cancer: do they have prognostic impact? Int J Colorectal Dis 2012; 27: 1295-301.

56. Kim SH, Chang HJ, Kim DY, et al. What is the ideal tumor regression grading system in rectal cancer patients after preoperative chemoradiotherapy? Cancer Res Treat 2016; 48: 998-1009.

57. Mandard AM, Dalibard F, Mandard JC, et al. Pathologic assessment of tumor regression after preoperative chemoradiotherapy of esophageal carcinoma: clinicopathologic correlations. Cancer 1994; 73: 2680-6.

58. Dworak O, Keilholz L, Hoffmann A. Pathological features of rectal cancer after preoperative radiochemotherapy. Int J Colorectal Dis 1997; 12: 19-23.

59. Ryan R, Gibbons D, Hyland JM, et al. Pathological response following long-course neoadjuvant chemoradiotherapy for locally advanced rectal cancer. Histopathology 2005; 47: 141-6.

60. Krasinskas AM. EGFR Signaling in Colorectal Carcinoma. Patholog Res Int 2011; 2011: 932932.

61. Goldstein NS, Armin M. Epidermal growth factor receptor immunohistochemical reactivity in patients with American Joint Committee on Cancer Stage IV colon adenocarcinoma: implications for a standardized scoring system. Cancer 2001; 92: 1331-46.

62. McKay JA, Murray LJ, Curran S, et al. Evaluation of the epidermal growth factor receptor (EGFR) in colorectal tumours and lymph node metastases. Eur J Cancer 2002; 38: 2258-64.

63. Spano JP, Fagard R, Soria JC, Rixe O, Khayat D, Milano G. Epidermal growth factor receptor signaling in colorectal cancer: preclinical data and therapeutic perspectives. Ann Oncol 2005; 16: 189-94.

64. Resnick MB, Routhier J, Konkin T, Sabo E, Pricolo VE. Epidermal growth factor receptor, c-MET, beta-catenin, and p53 expression as prognostic indicators in stage II colon cancer: a tissue microarray study. Clin Cancer Res 2004; 10: 3069-75.

65. de Castro-Carpeno J, Belda-Iniesta C, Casado Saenz E, Hernandez Agudo E, Feliu Batlle J, Gonzalez Baron M. EGFR and colon cancer: a clinical view. Clin Transl Oncol 2008; 10: 6-13.

66. Saltz LB, Meropol NJ, Loehrer PJ Sr, Needle MN, Kopit J, Mayer RJ. Phase II trial of cetuximab in patients with refractory colorectal cancer that expresses the epidermal growth factor receptor. J Clin Oncol 2004; 22: 1201-8.

67. Vallböhmer D, Zhang W, Gordon M, et al. Molecular determinants of cetuximab efficacy. J Clin Oncol 2005; 23: 3536-44.

68. Ogino S, Meyerhardt JA, Cantor M, et al. Molecular alterations in tumors and response to combination chemotherapy with gefitinib for ad- 
vanced colorectal cancer. Clin Cancer Res 2005; 11: 6650-6.

69. Geiersbach KB, Samowitz WS. Microsatellite instability and colorectal cancer. Arch Pathol Lab Med 2011; 135: $1269-77$.

70. Pino MS, Chung DC. Microsatellite instability in the management of colorectal cancer. Expert Rev Gastroenterol Hepatol 2011; 5: 385-99.

71. Samowitz WS. Evaluation of colorectal cancers for Lynch syndrome: practical molecular diagnostics for surgical pathologists. Mod Pathol 2015; 28 Suppl 1: S109-13.

72. Boland CR, Goel A. Microsatellite instability in colorectal cancer. Gastroenterology 2010; 138: 2073-87.

73. Guastadisegni C, Colafranceschi M, Ottini L, Dogliotti E. Microsatellite instability as a marker of prognosis and response to therapy: a metaanalysis of colorectal cancer survival data. Eur J Cancer 2010; 46: 2788-98.

74. Pritchard CC, Grady WM. Colorectal cancer molecular biology moves into clinical practice. Gut 2011; 60: 116-29.

75. Le DT, Uram JN, Wang H, et al. PD-1 blockade in tumors with mismatch-repair deficiency. N Engl J Med 2015; 372: 2509-20.

76. Le DT, Durham JN, Smith KN, et al. Mismatch repair deficiency predicts response of solid tumors to PD-1 blockade. Science 2017; 357: 409-13.

77. Roxburgh CS, McMillan DC. The role of the in situ local inflammatory response in predicting recurrence and survival in patients with primary operable colorectal cancer. Cancer Treat Rev 2012; 38: 451-66.

78. Kirilovsky A, Marliot F, El Sissy C, Haicheur N, Galon J, Pages F. Rational bases for the use of the Immunoscore in routine clinical settings as a prognostic and predictive biomarker in cancer patients. Int Immunol 2016; 28: 373-82.

79. Mlecnik B, Bindea G, Angell HK, et al. Integrative analyses of colorectal cancer show immunoscore is a stronger predictor of patient survival than microsatellite instability. Immunity 2016; 44: 698-711.

80. Galon J, Mlecnik B, Bindea G, et al. Towards the introduction of the 'Immunoscore' in the classification of malignant tumours. J Pathol 2014; 232: 199-209.

81. Galon J, Pagès F, Marincola FM, et al. Cancer classification using the Immunoscore: a worldwide task force. J Transl Med 2012; 10: 205.

82. Sepulveda AR, Hamilton SR, Allegra CJ, et al. Molecular biomarkers for the evaluation of colorectal cancer: guideline from the American Society for Clinical Pathology, College of American Pathologists, Association for Molecular Pathology, and the American Society of Clinical Oncology. J Clin Oncol 2017; 35: 1453-86.

83. Zaanan A, Shi Q, Taieb J, et al. Role of deficient DNA mismatch repair status in patients with stage III colon cancer treated with FOLFOX adjuvant chemotherapy: a pooled analysis from 2 randomized clinical trials. JAMA Oncol 2018; 4: 379-83.

84. Sargent DJ, Marsoni S, Monges G, et al. Defective mismatch repair as a predictive marker for lack of efficacy of fluorouracil-based adjuvant therapy in colon cancer. J Clin Oncol 2010; 28: 3219-26.

85. Overman MJ, McDermott R, Leach JL, et al. Nivolumab in patients with metastatic DNA mismatch repair-deficient or microsatellite instabilityhigh colorectal cancer (CheckMate 142): an open-label, multicentre, phase 2 study. Lancet Oncol 2017; 18: 1182-91.

86. Umar A, Boland CR, Terdiman JP, et al. Revised Bethesda Guidelines for hereditary nonpolyposis colorectal cancer (Lynch syndrome) and microsatellite instability. J Natl Cancer Inst 2004; 96: 261-8.

87. Boland CR, Thibodeau SN, Hamilton SR, et al. A National Cancer Institute Workshop on Microsatellite Instability for cancer detection and familial predisposition: development of international criteria for the determination of microsatellite instability in colorectal cancer. Cancer Res 1998; 58: 5248-57.

88. Adar T, Rodgers LH, Shannon KM, et al. A tailored approach to BRAF and MLH1 methylation testing in a universal screening program for Lynch syndrome. Mod Pathol 2017; 30: 440-7.

89. Buhard O, Cattaneo F, Wong YF, et al. Multipopulation analysis of polymorphisms in five mononucleotide repeats used to determine the microsatellite instability status of human tumors. J Clin Oncol 2006; 24: 241-51.

90. Goel A, Nagasaka T, Hamelin R, Boland CR. An optimized pentaplex PCR for detecting DNA mismatch repair-deficient colorectal cancers. PLoS One 2010; 5: e9393.

91. Van Cutsem E, Cervantes A, Adam R, et al. ESMO consensus guidelines for the management of patients with metastatic colorectal cancer. Ann Oncol 2016; 27: 1386-422.

92. Amado RG, Wolf M, Peeters M, et al. Wild-type KRAS is required for panitumumab efficacy in patients with metastatic colorectal cancer. J Clin Oncol 2008; 26: 1626-34.

93. Douillard JY, Oliner KS, Siena S, et al. Panitumumab-FOLFOX4 treatment and RAS mutations in colorectal cancer. N Engl J Med 2013; 369: 102334. 
94. Rui Y, Wang C, Zhou Z, Zhong X, Yu Y. K-Ras mutation and prognosis of colorectal cancer: a meta-analysis. Hepatogastroenterology 2015; 62: 1924.

95. Phipps AI, Limburg PJ, Baron JA, et al. Association between molecular subtypes of colorectal cancer and patient survival. Gastroenterology 2015; 148: 77-87.

96. Sinicrope FA, Shi Q, Smyrk TC, et al. Molecular markers identify subtypes of stage III colon cancer associated with patient outcomes. Gastroenterology 2015; 148: 88-99.

97. Taieb J, Le Malicot K, Shi Q, et al. Prognostic value of BRAF and KRAS mutations in MSI and MSS stage III colon cancer. J Natl Cancer Inst 2017; 109: djw272.

98. Schirripa M, Bergamo F, Cremolini C, et al. BRAF and RAS mutations as prognostic factors in metastatic colorectal cancer patients undergoing liver resection. Br J Cancer 2015; 112: 1921-8.

99. Wang L, Cunningham JM, Winters JL, et al. BRAF mutations in colon cancer are not likely attributable to defective DNA mismatch repair. Cancer Res 2003; 63: 5209-12.

100. Loes IM, Immervoll H, Sorbye $\mathrm{H}$, et al. Impact of KRAS, BRAF, PIK3CA, TP53 status and intraindividual mutation heterogeneity on outcome after liver resection for colorectal cancer metastases. Int J Cancer 2016; 139: 647-56.

101. Di Nicolantonio F, Martini M, Molinari F, et al. Wild-type BRAF is required for response to panitumumab or cetuximab in metastatic colorectal cancer. J Clin Oncol 2008; 26: 5705-12.

102. Pietrantonio F, Petrelli F, Coinu A, et al. Predictive role of $B R A F$ mutations in patients with advanced colorectal cancer receiving cetuximab and panitumumab: a meta-analysis. Eur J Cancer 2015; 51: 587-94. 

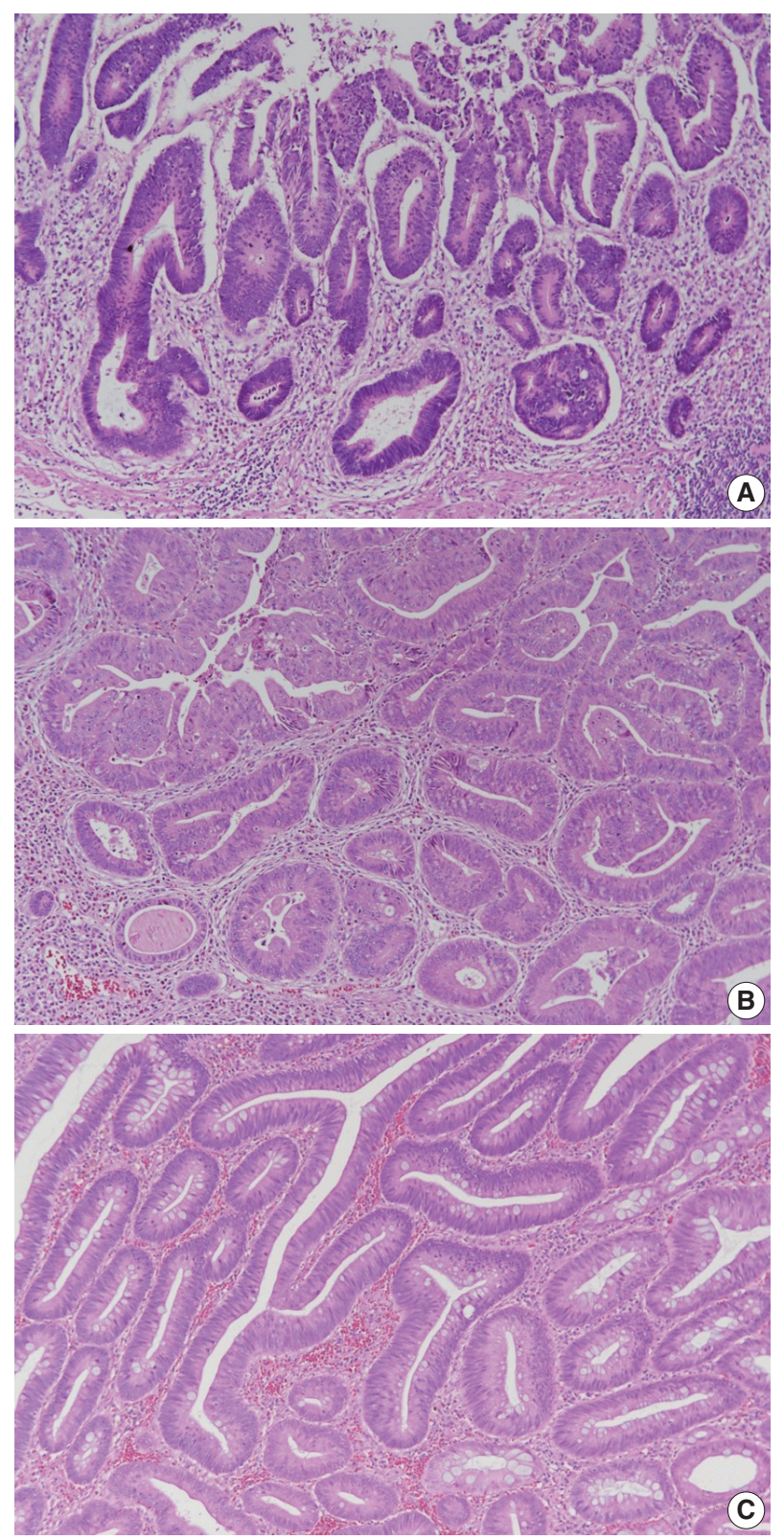

Fig. 1. Histologic features of intramucosal carcinoma. (A) The intramucosal carcinoma shows irregular invasive glands accompanied by desmoplasia. (B) The glands show excessive budding and luminal serration, which is highly suspicious for disruption of the basement membrane. (C) The elongated nuclei are seen in lowgrade dysplasia, regardless of the ratio to the cell length. 

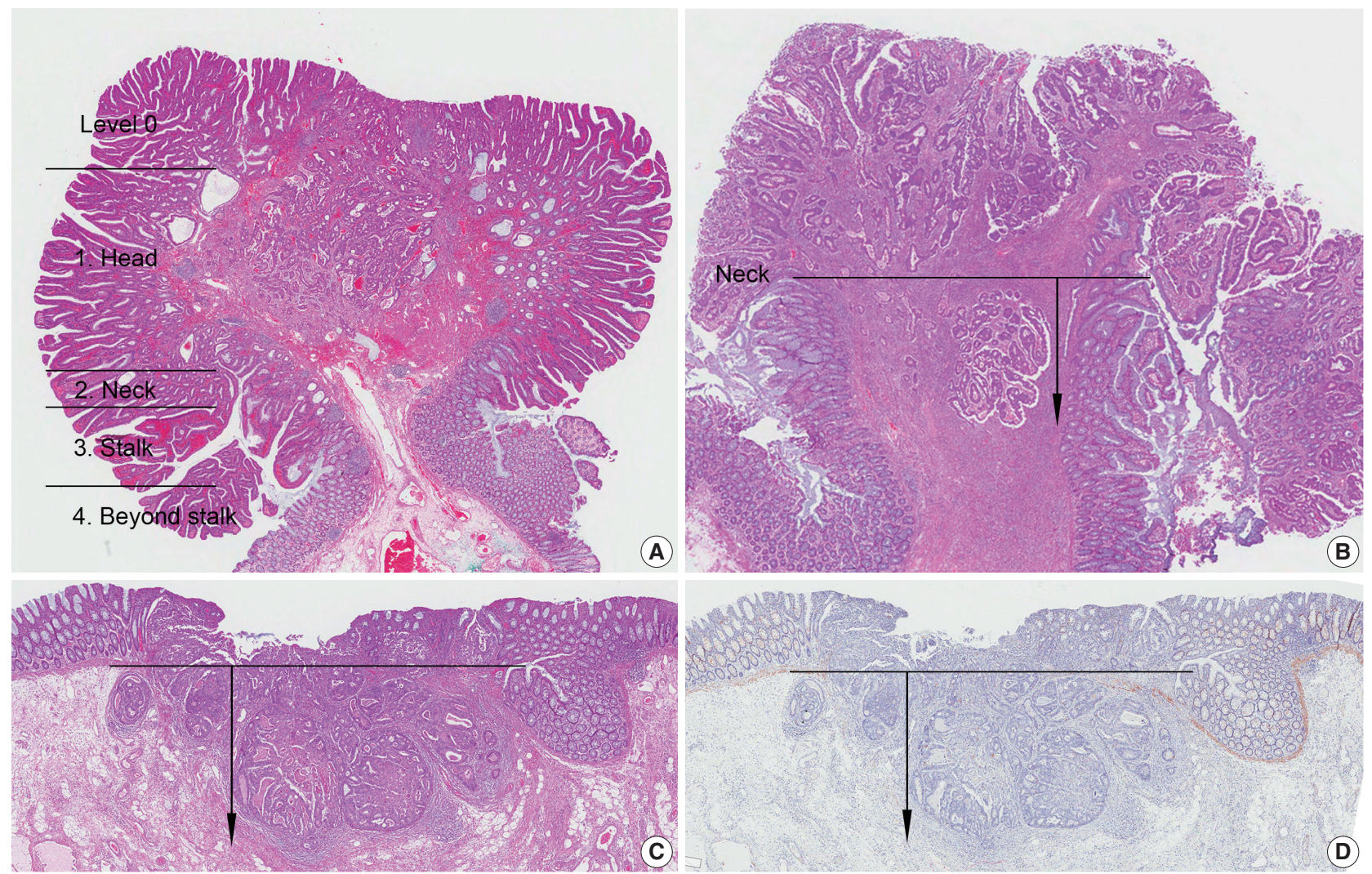

Fig. 2. Measuring depth of invasion in tumors with submucosal invasion. (A) Haggitt level of invasion is composed of head, neck, stalk, and beyond stalk in pedunculated tumors. (B) The depth of invasion should be measured from the neck of the polyp (Haggitt level 2). (C) In cases with disrupted muscularis mucosae, the depth of submucosa invasion is measured from a continuous line of the residual muscularis mucosae. (D) To highlight indistinct muscularis mucosae, immunohistochemistry for desmin may be performed. 

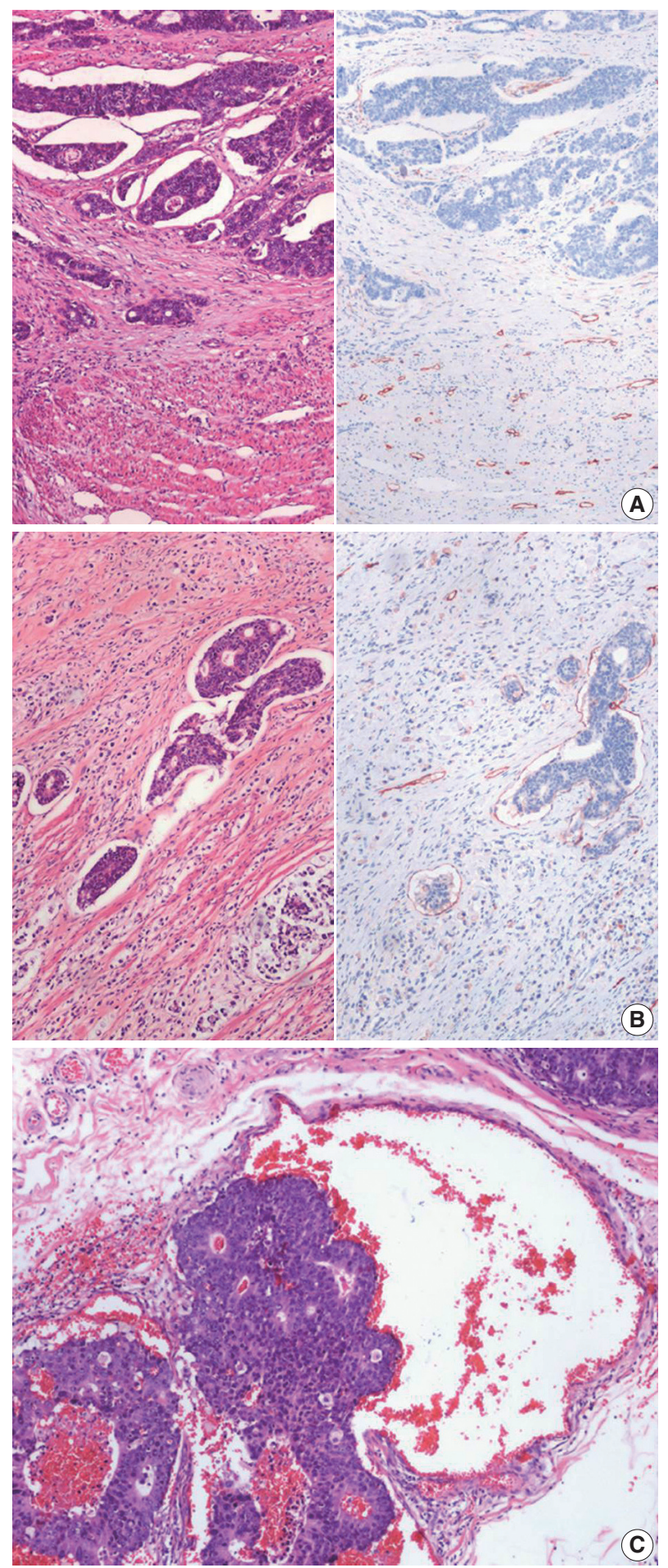

Fig. 3. Histologic features of lymphatic invasion and venous invasion. (A) Tumor clusters with retraction artifacts can be misinterpreted as lymphatic invasion (H\&E stain and D2-40 immunohistochemical stain). (B) Tumor invasion of small vessels is considered as lymphatic invasion (H\&E stain and D2-40 immunohistochemical stain). (C) Tumors involving vessels with identifiable smooth muscle layer or elastic lamina are considered as venous invasion. 


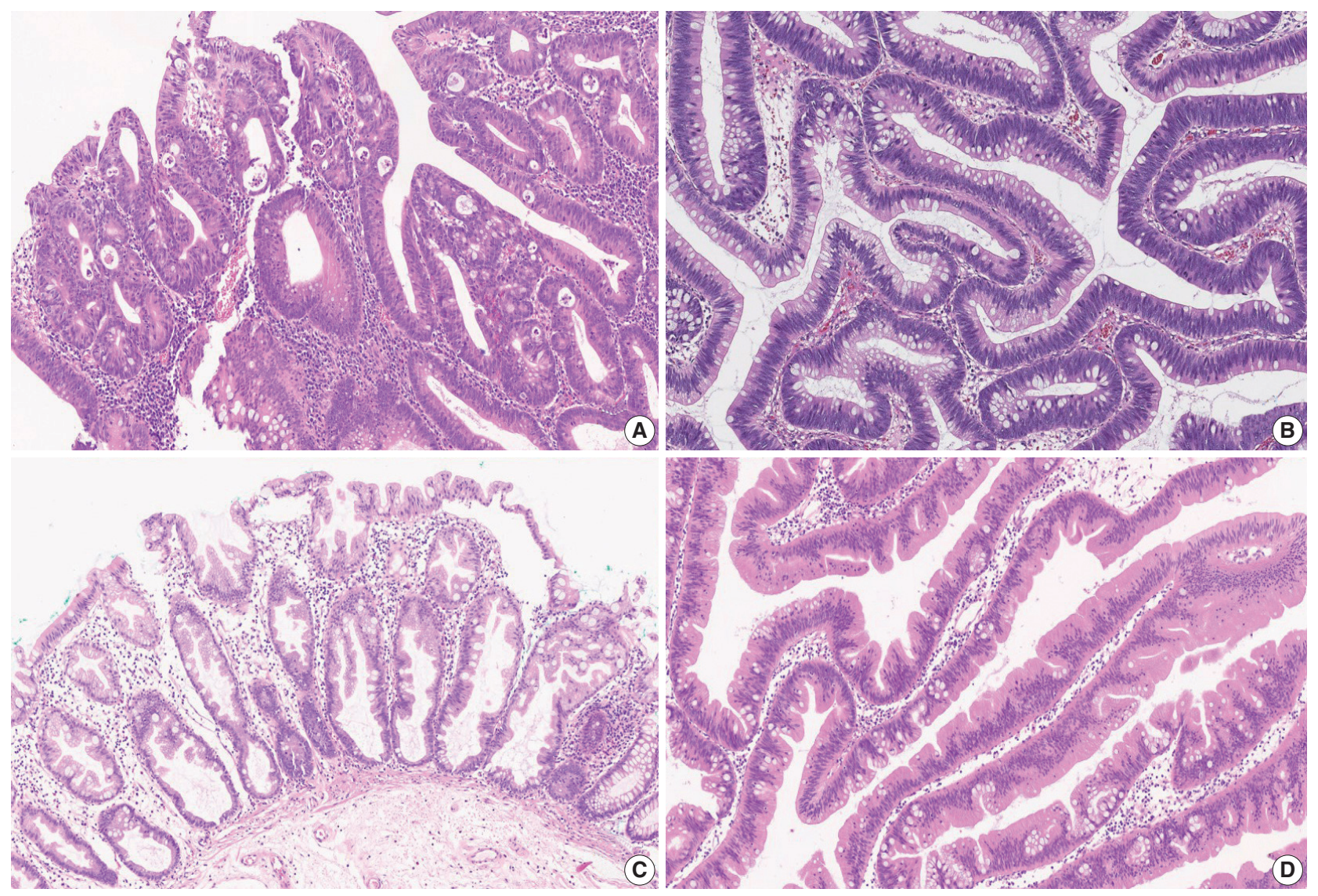

Fig. 4. Histologic features of premalignant lesions of the colorectum. (A) Tubular adenoma with high-grade dysplasia. Note the architectural complexity including cribriform pattern or back-to-back fusion of dysplastic glands. (B) Tubulovillous adenoma with low-grade dysplasia. Note the retained cellular polarity with pseudostratified, elongated nuclei. (C) Sessile serrated adenoma without dysplasia. Note the dilated base of crypts. (D) Traditional serrated adenoma. Note the deep-invaginated pattern of crypt serration with hypereosinophilic cytoplasm and pencillated nuclei. 

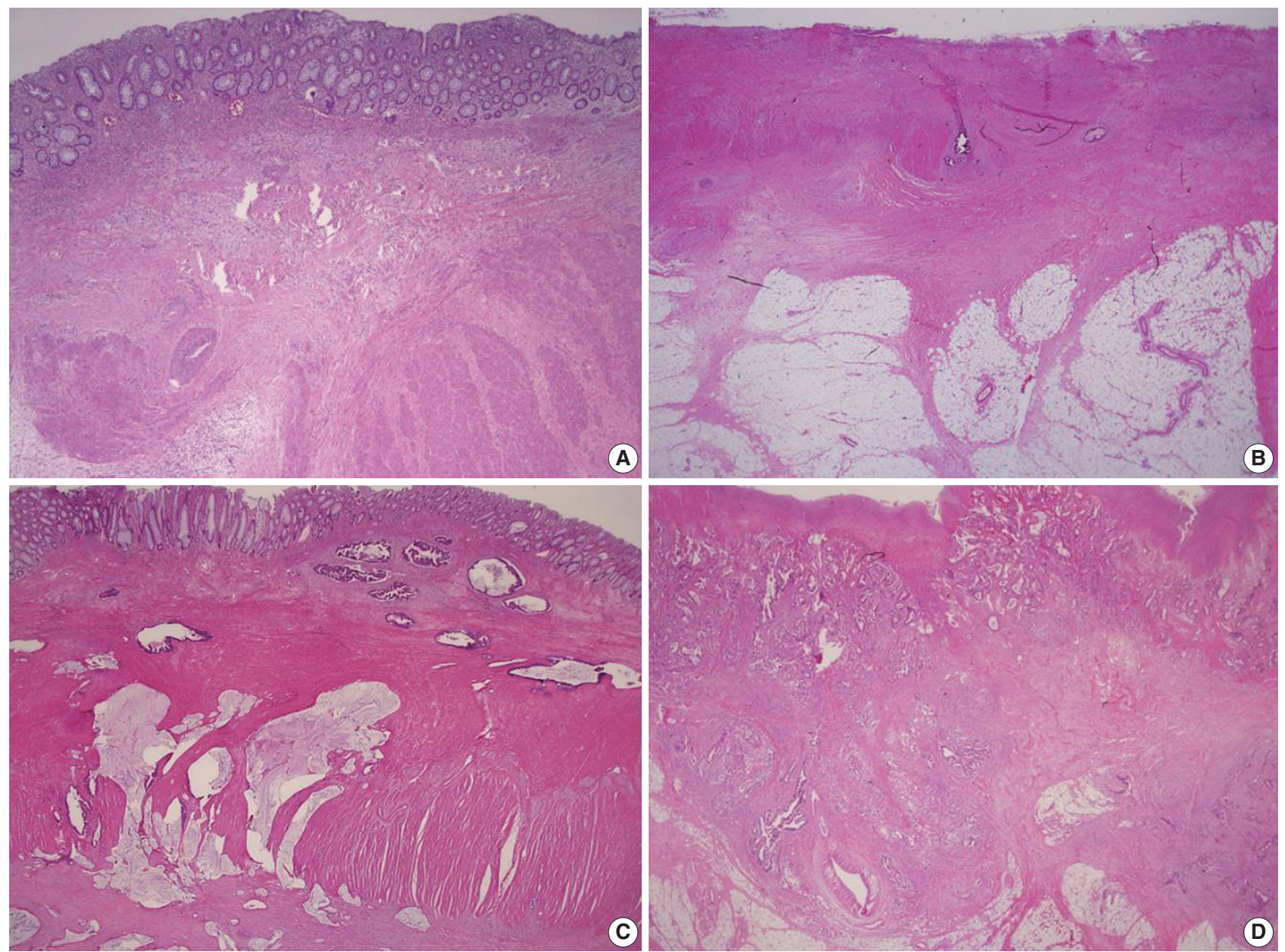

Fig. 5. Recommended tumor regression grading system. (A) Grade 0, complete response. No residual tumor cells are identified. (B) Grade 1 , near complete response. The tumor bed contained abundant fibrosis with only a few or scattered tumor cells. (C) Grade 2, partial response. Residual tumor glands are easily identified in tumor bed. (D) Grade 3, poor or no response. The tumor cells do not demonstrate any response to chemoradiotherapy because abundant residual adenocarcinoma is present. 


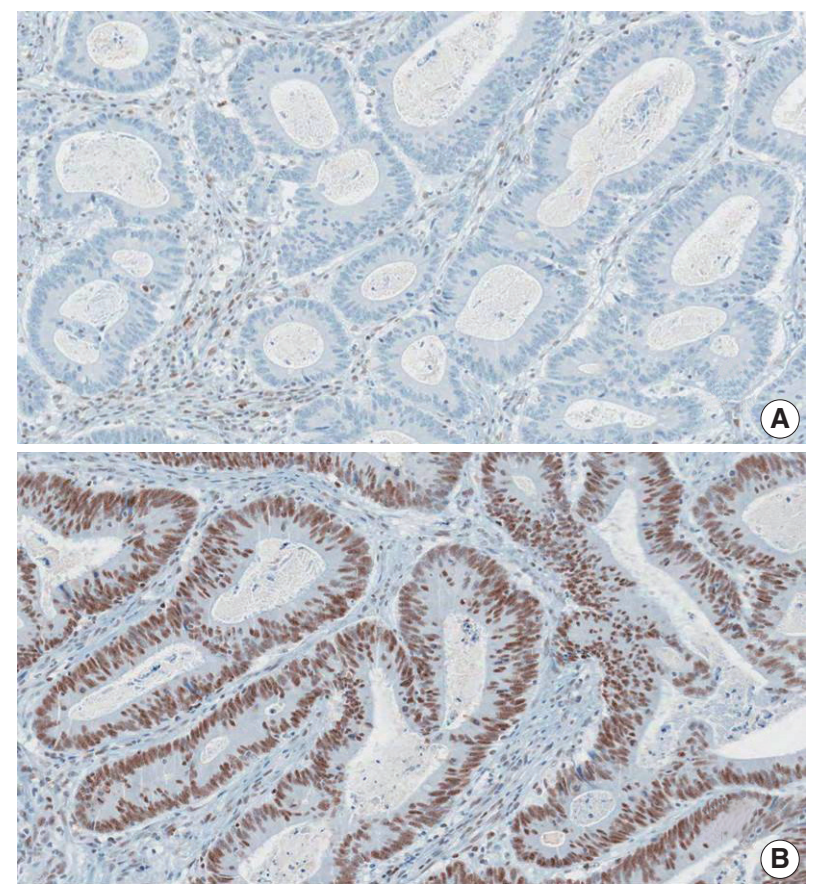

Fig. 6. A representative case of colorectal cancer with MMR deficiency (MLH1 deficiency). (A) MLH1 immunohistochemical staining showed negativity of nuclear expression in tumor cells. Note the retained nuclear expression in adjacent inflammatory cells. (B) $\mathrm{MSH} 2$ immunohistochemical staining demonstrated positivity of nuclear expression in tumor cells. 